\title{
FORMAS DE ORGANIZAÇ̃̃o DA PRODUÇÃO E DECISÕES DE TERCEIRIZAÇÃO NA CITRICULTURA
}

\author{
DIOGO SUZIGAN DRAGONE
}

Dissertação apresentada à Escola Superior de Agricultura "Luiz de Queiroz", Universidade de São Paulo, para obtenção do título de Mestre em Ciências, Área de Concentração: Economia Aplicada.

\footnotetext{
P I R A C I C A B A

Estado de São Paulo - Brasil
}

Outubro - 2003 


\title{
FORMAS DE ORGANIZAÇÃO DA PRODUÇÃO E DECISÕES DE TERCEIRIZAÇÃO NA CITRICULTURA
}

\section{DIOGO SUZIGAN DRAGONE}

Engenheiro Agrônomo

Orientador: Prof. Dr. EVARISTO MARZABAL NEVES

\begin{abstract}
Dissertação presentada à Escola Superior de Agricultura "Luiz de Queiroz", Universidade de São Paulo, para obtenção do título de Mestre em Ciências, Área de Concentração: Economia Aplicada.
\end{abstract}

P I R A C I C A B A

Estado de São Paulo - Brasil

Outubro - 2003 
Dados Internacionais de Catalogação na Publicação (CIP)

DIVISÃO DE BIBLIOTECA E DOCUMENTAÇÃO - ESALQ/USP

Dragone, Diogo Suzigan

Formas de orga nização da produção e decisões de terceiriza ção na citric ultura / Diogo Suzigan Dragone. - - Piracicaba, 2003.

$108 \mathrm{p}$.

Dissertação (mestrado) - - Escola Superior de Agricultura Luiz de Queiroz, 2003.

Bibliografia.

1. Citric ultura 2. Custo de transação 3. Organização industrial 4. Tercenização I. Título

CDD 338.17431

'Permitida a cópia total ou parcial deste documento, desde que citada a fonte - O autor" 


\section{AGRADECIMENTOS}

Ao Prof. Evaristo Marzabal Neves, pela cordialidade, dedicação e eficiência na orientação do mestrado, que em muito contribuíram para minha vida acadêmica e pessoal.

Aos professores Alexandre Mendonça de Barros (ESALQ/USP), Márcia Azanha Ferraz Dias de Moraes (ESALQ/USP), Marcos Fava Neves (FEARP/USP), Pedro Valentim Marques (ESALQ/USP), Ronald P. Muraro (Universidade da Flórida) e Thomas H. Spreen (Universidade da Flórida), pelas inúmeras sugestões e suportes que deram à pesquisa. E aos doutores Waldir Fernandes Junior e Stephen H. Futch pelas inúmeras sugestões que deram à pesquisa.

Aos agentes econômicos entrevistados em São Paulo e Flórida que tiveram grande participação na construção e estruturação deste trabalho e ainda pelas inúmeras sugestões e ajudas que deram à pesquisa.

A todos os professores, funcionários e colegas do curso de mestrado do Departamento de Economia, Administração e Sociologia da ESALQ/USP que, direta ou indiretamente, colaboraram com a realização deste trabalho, em especial, à secretária Maria Aparecida Maielli Travalini e à bibliotecária Srta. Ligiana Clemente do Carmo, da Biblioteca do DEAS da ESALQ/USP, pela revisão competente das referências bibliográficas e a Srta. Mariangela G. Cruciani, pela cautelosa e atenta revisão ortográfica deste trabalho.

À minha família que me apoiou bastante nesta etapa da minha vida. 


\section{SUMÁRIO}

Página

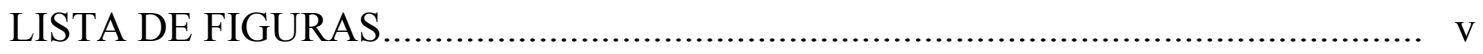

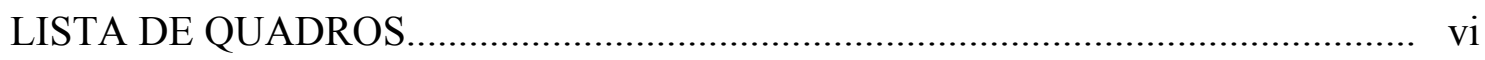

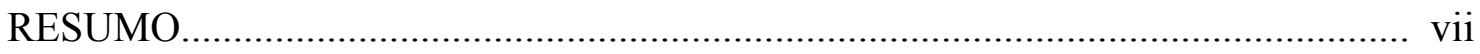

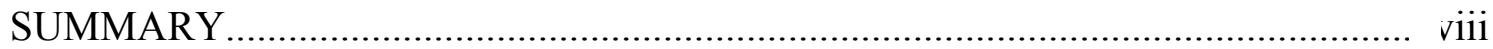

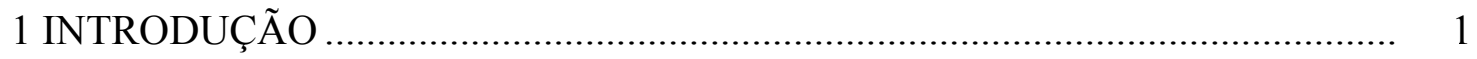

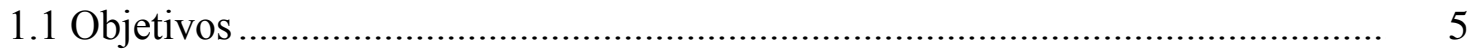

2 ARCABOUÇO TEÓRICO E METODOLOGIA .................................................. 7

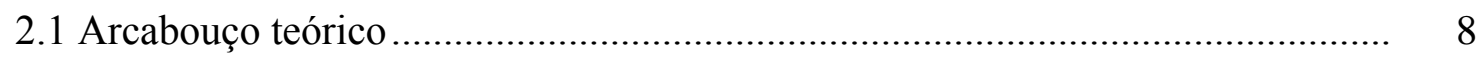

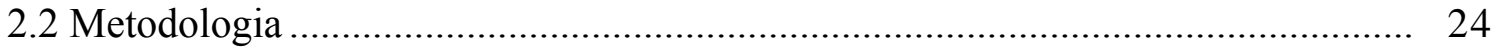

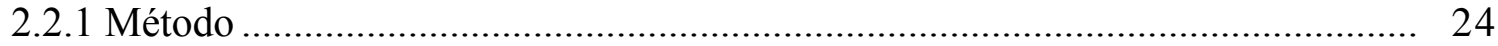

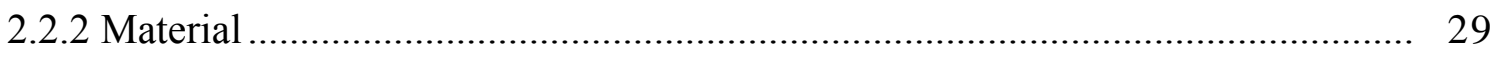

3 REVISÃO DE LITERATURA ................................................................... 32

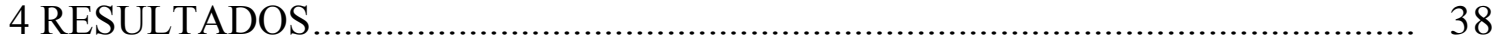

4.1 Formas de organização da produção: Brasil e EUA …......................................... 38

4.1.1 Formas de organizações encontradas na Flórida (EUA) .................................. 38

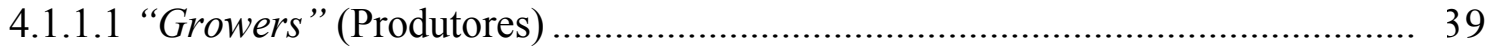

4.1.1.2 “Absentee owners” (Proprietários ausentes) ............................................ 40

4.1.1.3 “Caretakers" (Empresas prestadoras de serviços) ...................................... 41

4.1.1.4 Firmas de investimentos e gerenciamento .............................................. 42

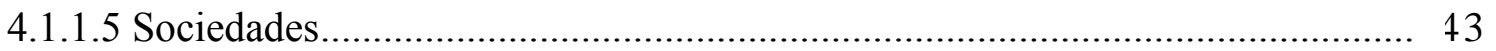

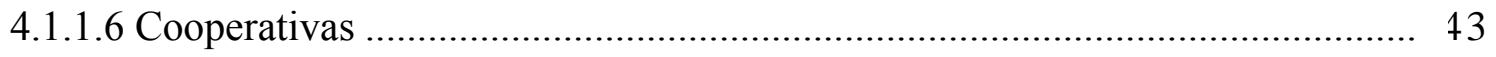

4.1.2 Formas de organizações encontradas no Estado de São Paulo (Brasil).............. 46

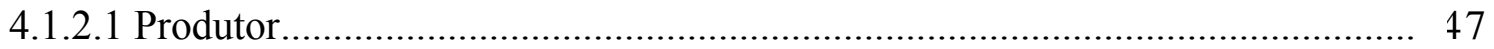




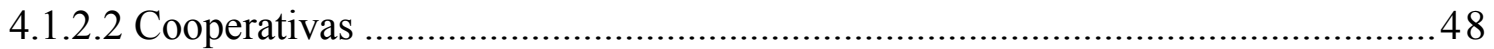

4.1.2.3 Empresas ……....................................................................... 50

4.1.2.4 "Pool" ...................................................................................... 51

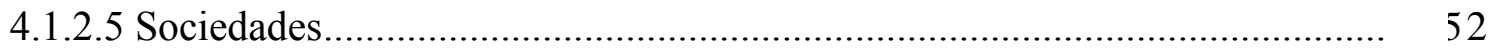

4.1.3 Comparações entre os dois modelos de negócio.............................................. 55

4.2 Decisões de terceirização na produção e investimentos externos na citricultura 62

4.2.1 Culturais (Ambiente Institucional) ................................................................62

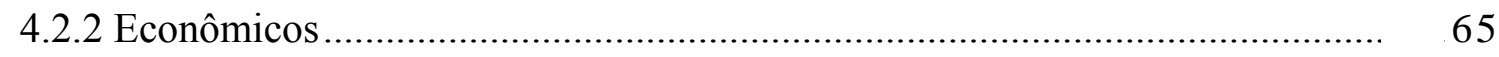

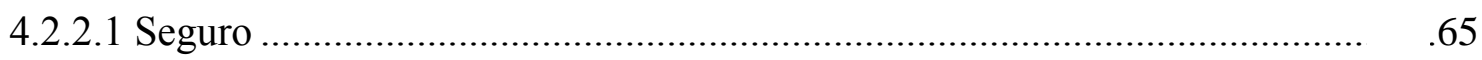

4.2.2.2 Crédito: governamental e investimentos externos ...................................... . .66

4.2.2.3 Retornos e variabilidade de investimentos .................................................67

4.2.2.4 Políticas protecionistas......................................................................... .72

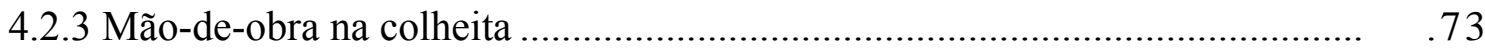

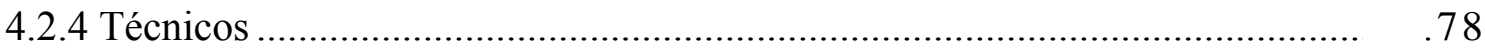

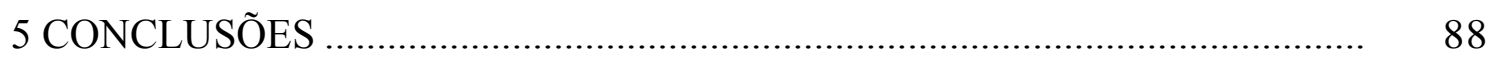

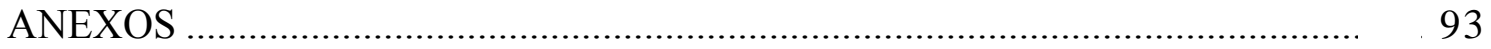

REFERÊNCIAS BIBLIOGRÁFICAS........................................................... . 102 


\section{LISTA DE QUADROS}

Página

1 Os benefícios e os custos que uma empresa/firma tem ao utilizar o mercado.......... 17

2 Entrevistas desenvolvidas por categorias de estruturas de negócio na Flórida.......... 31

3 Entrevistas desenvolvidas por categorias de estruturas de negócio em São ............. 31

4 Produção de laranja na Flórida: uma visão de propriedade e gerenciamento........... 46

5 Produção de laranja no estado de São Paulo: uma visão de propriedade e............... 54

6 Flórida x São Paulo: principais diferenças e similaridades. .................................. 59

7 Caracterização da especificidade dos ativos, incerteza e frequência de algumas operações da produção cítrica de São Paulo......................................................... 86

8 Questionário utilizado no levantamento de informações no estado de São Paulo e

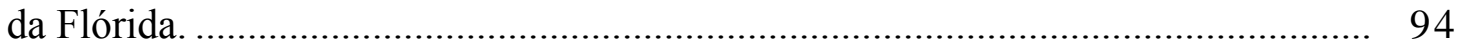




\section{LISTA DE FIGURAS}

Página

1 Especificidade de ativos e mecanismos de governança...................................... 14

2 Classificação de dados de pesquisa..................................................................... 25

3 Classificação dos processos de uma pesquisa qualitativa..................................... 27

4 Comparação entre dois portifólios de ações de 1970-1990 .................................... 35

5 Relações estabelecidas entre os tipos de negócios na citricultura da Flórida........... 45

6 Relações existentes entre os tipos de negócios na citricultura de São Paulo............. 53 


\title{
FORMAS DE ORGANIZAÇÃO DA PRODUÇÃO E DECISÕES DE TERCEIRIZAÇÃO NA CITRICULTURA
}

\author{
Autor: DIOGO SUZIGAN DRAGONE \\ Orientador: Prof. Dr. EVARISTO MARZABAL NEVES
}

\section{RESUMO}

Este estudo tem como objetivo analisar as formas de organização da produção em São Paulo (Brasil) e Flórida (EUA) e as decisões de terceirização na produção e investimentos externos na citricultura em São Paulo - suas possibilidades, potencialidades e limitações. Para a fundamentação empírica-teórica, são estudados modelos e relações contratuais existentes na citricultura dos dois países. Entrevistas e levantamentos de dados primários são efetuados, buscando informações qualitativas com agentes econômicos de instituições privadas e públicas ligadas ao setor cítrico paulista, via pesquisa direta (não simulada) por meio de entrevistas em profundidade. Incorporam-se ainda entrevistas realizadas nos EUA, e extensões recentes para o setor cítrico da Flórida. Conclui-se que as modalidades de produção cítrica das duas regiões têm similaridades e diferenças em função das relações contratuais, dos tipos de agentes econômicos envolvidos, das culturas organizacionais regionais e das características próprias da citricultura de cada região, e, que a terceirização do setor pode ser uma direção futura abrindo outros cenários na organização e relações negociais na citricultura. 


\title{
ORGANIZATIONAL FORMS OF CITRUS PRODUCTION AND OUTSOURCING DECISIONS IN CITRICULTURE
}

\author{
Author: DIOGO SUZIGAN DRAGONE \\ Adviser: Prof. Dr. EVARISTO MARZABAL NEVES
}

\section{SUMMARY}

The objective of this study is to analyze the organizational forms of citrus production in the Sao Paulo (Brazil) and Florida (USA) and the production outsourcing decisions and external investments in the Sao Paulo citriculture (i.e., its possibilities, potentials and limitations). For the theoretical and empirical analysis, models and contractual production relations in the two countries have been studied. Interviews have been made and primary sources data have been collected, obtaining qualitative data from economic agents related to public and private institutions of the Sao Paulo citrus industry, via direct research method (non simulated) through in-depth interviews. Interviews on US citriculture contract tools and recent extension services on the Florida citrus industry have also been included. A conclusion of this study is that the kinds of business of both regions have differences and similarities with respect contractual relations, strategic and organizational management, types of economic agents involved, and the peculiar characteristics of each citrus production region. Another finding of this study is that outsourcing might be one of the future ways of opening other scenarios in the organization and negotiation relations of the citriculture. 


\section{INTRODUÇÃO}

Os Estados de São Paulo (Brasil) e da Flórida (EUA) produzem mais de $50 \%$ de toda a laranja consumida e industrializada no mundo (FAO, 2002). Na Flórida, a indústria cítrica é a segunda maior em importância, apenas atrás da indústria de turismo; em São Paulo, o suco concentrado é o segundo maior na pauta de exportações paulistas por produto, perdendo apenas para a indústria aeronáutica - EMBRAER (SECEX, 2002). Em São Paulo e na Flórida, a citricultura gera divisas superiores a US\$1 bilhão anuais, sendo que os dois estados possuem regiões produtoras específicas, que juntas, produzem aproximadamente $90 \%$ de todo o Suco de Laranja Concentrado e Congelado (SLCC) ${ }^{1}$ comercializado no mundo (Associação Brasileira dos Exportadores de Citrus ABECITRUS, 2002). Estabelendo-se um comparativo, nenhuma outra indústria no mundo apresenta tal concentração, nem mesmo a de diamantes.

A cadeia produtiva do SLCC é bem ampla quando se consideram todos os elos do sistema produtor. Contudo, este estudo está focado nas interações existentes entre os elos da produção de matéria-prima (setor de produção de fruta), os propulsores da ativação e da dinâmica dos elos que estão para frente e para trás no complexo cítrico.

Estudo desenvolvido por NEVES et al. (2002) mostrou que, em 1999, a cadeia citrícola no Estado de São Paulo movimentou recursos financeiros na ordem de US\$ 3,8 bilhões nos eixos central (US\$ 3,4 bilhões) e de suporte (US\$ 438 milhões).

${ }^{1}$ SLCC - conhecido no mercado internacional por FCOJ (Frozen Concentrated Orange Juice) 
Boa parcela dessa movimentação se deveu à produção primária no campo (cerca de US\$ 900 milhões) e às divisas carreadas com exportação (cerca de US\$ 1,3 bilhão) e seu entorno de suporte (pedágio, Porto de Santos, combustíveis, transportadoras, embalagens etc). É evidente a importância da produção e da industrialização da laranja que corresponde a quase $60 \%$ da movimentação financeira; por isso, este estudo está focado nos agentes econômicos desses elos da cadeia.

A acirrada competição (concorrência) entre os meios de produção da citricultura em São Paulo e na Flórida impõe a busca por investimentos alternativos contratuais que revelem a racionalização e otimização no uso de serviços dos fatores de produção da laranja. Uma direção futura nas relações negociais/formas de organização pode estar na terceirização das atividades da produção cítrica, pois esta poderia propiciar diferentes/novas alternativas para planejamento e organização da produção cítrica. Entende-se por terceirização ${ }^{2}$ por uma contratada, todo o serviço é realizado fora da estrutura de uma empresa, cujo primeiro impacto favorável de sua implementação seria a transformação de custo fixo em variável, ou seja, não seria preciso investir capital na compra de máquinas, que ficam parcialmente ociosas em boa parte do ciclo de produção, nem carregar grandes estoques de insumos, permitindo a racionalização do produto.

Com a terceirização é possível obter-se outras vantagens tecnogerenciais, além das econômicas. Uma delas é a introdução de novas tecnologias na lavoura, pois a terceirização pode amortizar os custos de máquinas na propriedade (diminuição de capital investido), e também oferecer infra-estrutura (tratores, pulverizadores, adubadeiras, etc), qualidade na aplicação dos defensivos e na tecnologia empregada, visto que a prestadora de serviço está diretamente ligada, por meio de parcerias, aos fabricantes de equipamentos e de insumos. Além disso, oferece mão-deobra especialmente treinada no maquinário, o que é muito importante para uma operação eficiente, pois, comumente depara-se com subutilização de equipamentos sofisticados

\footnotetext{
${ }^{2}$ Terceirização é definido por Neves (1995) como o processo de transferir etapas inseridas no mesmo comando decisório, dentro das fronteiras de uma mesma empresa, para terceiros. Referencial teórico mais detalhado se encontra no arcabouço teórico deste estudo.
} 
por falta de conhecimento dos operadores, proporcionando melhor gerenciamento e aperfeiçoamento de instrumentais de planejamento e controle da produção.

Os modelos de terceirização no âmbito internacional têm sido bemsucedidos porque têm agregado produtos e serviços ao setor produtivo. Essa combinação pode dar ao agricultor o benefício de focar-se em outras etapas da cadeia de produção, tão importantes quanto à de aplicação dos defensivos. Essa combinação é compreensível pelos agentes econômicos, porque sempre agrega benefícios a atividade empresarial, quando se sabe que a terceirizada (empresa que contrata serviços) precisa fazer investimentos volumosos em infra-estrutura, como no suporte prestado e na aquisição de máquinas.

$\mathrm{Na}$ agricultura americana mais de $50 \%$ da produção colhida é terceirizada, mas essa porcentagem é obtida porque atinge médios e grandes produtores. Já na Argentina, no caso dos grãos, o modelo é um pouco diferente do aplicado no Brasil e bem mais abrangente. Isso porque somente uma pequena parte dos grandes produtores usa equipamentos tão sofisticados quanto os usados pelas prestadoras de serviço brasileiras. Uma outra parcela é composta por grande número de agricultores, que possui pulverizadores e propõe-se a prestar serviço a outros fazendeiros, oferecendo a terceirização por venda direta, de porta em porta, servindo de exemplo para outras atividades com potencial de terceirização (Fundação Cargill, 2000).

Os tipos de negócios existentes no elo produtivo (produção agrícola) da cadeia são esclarecedoras na determinação de cada estrutura produtiva, porque são essas interações que fornecem as características e o potencial de cada região produtora. Existem problemas vivenciados pelos produtores de ambas as regiões, em São Paulo citricultura mais familiar e não terceirizada - e na Flórida, mais empresarial e terceirizada; assim, a descrição dos sistemas nos Estados Unidos e no Brasil facilitaria a busca por alternativas que auxiliassem na organização e no estabelecimento pleno da indústria cítrica no mundo. 
Provavelmente, as duas regiões mostram similaridades e algumas diferenças com relação aos agentes econômicos, considerando-se as dimensões e a importância da citricultura em função da participação intensiva dos três setores da economia, principalmente nos EUA. Dessa forma, as estruturas de negócio, relacionando-se os fundos de investimentos, gerenciamento da produção e propriedade da terra, poderão ser bem diferentes em São Paulo e na Flórida, porque as regiões apresentam diferentes ambientes institucionais, estruturas de governança e especificidade dos ativos conforme a teoria descrita por Williamson (1985) e detalhada no arcabouço teórico deste estudo.

Dados preliminares demonstram que a citricultura da Flórida está amparada por uma estrutura de negócios com alternativas de formas de organizações bem mais complexas e amplas quando comparadas com as de São Paulo. Essas organizações de negócios envolvendo diferentes agentes econômicos permitem, consideravelmente, que haja uma separação entre os recursos de propriedade usados na produção e os conhecimentos econômicos e técnicos necessários para o gerenciamento do negócio. Investidores de fora do Estado, sem conhecimento específico sobre a produção cítrica, podem investir capital na produção de laranja e ter a maioria das técnicas gerenciais desenvolvidas por organizações e agentes especializados.

Segundo Dragone et al. (2002), nos EUA mais de 50\% dos proprietários de terra são investidores, que, geralmente, não utilizam a agricultura como seu principal negócio; por sua vez, em São Paulo, os produtores de laranja desenvolvem grande parte das tarefas gerenciais necessárias ao negócio. Firmas especializadas em serviços terceirizados de gerenciamento e técnicos são raras, dificultando a separação entre a propriedade e o gerenciamento do negócio cítrico. A maioria das grandes fazendas de laranja é de propriedade de produtores tradicionais, que estão no ramo há muito tempo. Desta forma, Dragone et al. (2002) verificaram que a maioria dos produtores de laranja no Brasil tem como seu principal negócio a própria agricultura. 
Dadas às semelhanças e diferenças existentes entre os agentes econômicos nas negociações da citricultura dos dois Estados produtores, torna-se importante o conhecimento das relações contratuais e as características que se estabelecem, tanto em São Paulo como na Flórida, bem como os instrumentos de organização e racionalização de uso e serviços de fatores de produção que controlem e otimizem o fluxo de caixa e elevem a competitividade dos elos mais importantes da cadeia cítrica.

\section{$1.1 \quad$ Objetivos}

As diferentes estruturas de produção vigentes nos dois maiores produtores mundiais de suco de laranja e a escassez de trabalhos relatando as características e formas de organização dos agentes econômicos envolvidos na citricultura são motivos para o estudo e a compreensão das relações negociais que se estabelecem entre esses produtores regionais.

Neste estudo perseguem-se os seguintes objetivos:

1. Descrever e analisar as formas de organização da produção da citricultura no Estado da Flórida (EUA) e no de São Paulo (Brasil);

2. Discutir as decisões de terceirização na produção e investimentos externos na citricultura, ressaltando suas potencialidades, possibilidades e suas limitações.

\subsection{Estrutura do trabalho}

Este trabalho está dividido em cinco seções. A primeira contém esta introdução e os objetivos. Na segunda seção são discutidos o arcabouço teórico e a 
metodologia do estudo. A revisão de literatura encontra-se na terceira seção. Na quarta são analisados os resultados do estudo por meio das formas de organização de produção nos dois Estados; os motivos deste estudo, descrevendo-os e discutindo seus aspectos principais. Essa descrição visa facilitar o entendimento do próprio trabalho, oferecendo o esclarecimento inicial sobre as estruturas organizacionais da produção cítrica e sobre a análise das potencialidades e possibilidades de uso da terceirização e de investimentos externos na citricultura, que constam do segundo objetivo deste estudo, e as discussões pertinentes. Finalizando, as conclusões. 


\section{ARCABOUÇO TEÓRICO E METODOLOGIA}

Na seção introdutória, buscou-se delimitar a importância da citricultura no mundo e alguns aspectos principais das duas principais regiões de produção cítrica, os Estados de São Paulo, no Brasil e da Flórida, nos EUA. Procurou-se estabelecer a aproximação e a interação entre os instrumentos de organização, visando o aprofundamento teórico para melhor compreensão das ferramentas científicas existentes na literatura com as estruturas de governança empresarial, indispensáveis também no estudo das possibilidades e potencialidades do mecanismo de terceirização no negócio cítrico.

Para atendimento do outro objetivo do estudo - análise das decisões de terceirização na atividade de produção cítrica em São Paulo - buscou-se apoio na Nova Economia Institucional (NEI), principalmente por meio dos estudos de Williamson (1985) e North (1990). A NEI é apresentada de forma breve, buscando-se referenciar os aportes relevantes para a análise. Além desses autores, o estudo se apóia também em Besanko (1996) e Brickley (2001), que apresentam aspectos da NEI de forma aplicada e englobando pontos não aprofundados por Williamson. Também são referenciados trabalhos nacionais aplicados, entre eles, o de Zylberztajn (1995) e de Azevedo (1996). Na teoria sobre terceirização utilizam-se referências do SEBRAE (1999), de Brickley (2001) e Neves (1995), enfatizando-se as vantagens, desvantagens e caracterizações desse tipo de atividade.

Metodologicamente, o estudo apóia-se em Malhotra (2001), que apresenta as formas de se realizar pesquisa para obtenção de dados e informações visando à caracterização dos diferentes tipos de organizações. 


\subsection{Arcabouço teórico}

A Nova Economia Institucional (NEI) surgiu da contribuição de vários autores, a partir do trabalho de Coase (1937) - The Nature of the Firm. A NEI prega que as instituições (regras das atividades - leis) são importantes e susceptíveis na análise; a NEI é diferente, porque não tem o preço, como principal fator na caracterização do mercado e sim outros fatores como as organizações e suas atuações, mas, não hostil à teoria ortodoxa, e sim agregando as; e, ainda, consegue o agrupamento interdisciplinar do Direito, Economia e Teoria das Organizações. São duas as principais correntes complementares na NEI: a de Williamson (1985) com as Instituições de Governança e a corrente teórica sobre o Ambiente Institucional de North (1990).

A principal contribuição da NEI é a abertura do caminho para a explicação da gênese da firma, isto é, ela é vista através de aspectos organizacionais ou de relacionamento com os clientes, antes ignorados na teoria neoclássica, na qual o preço é o seu foco central.

Coase (1988) descreve que a firma não seria somente um espaço de transformação do produto, mas também um espaço para se coordenar as ações dos agentes. Assim, pode-se dizer que, no limite, toda a atividade de produção e de alocação poderia ser realizada dentro da firma. $\mathrm{O}$ autor divide sua análise em duas formas de coordenação: o mercado e a firma, aspectos que serão explorados por diversos autores como Williamson (1985), Besanko (1996) e Brickley (2001).

A firma e o mercado concorrem de maneira a organizar a produção, gerando estruturas de custos de produção, escalas e estruturas de governança distintos e com particularidades específicas para cada situação. Coase (1988) reconhece a existência dos custos de transação, que são os custos de coleta de preços vigentes no mercado, custos de negociação e de contratos; isto é, são custos não ligados à produção, mas que surgem à medida que os agentes se relacionam entre si e quando aparecem os 
problemas decorrentes da coordenação. Assim, os custos de transação são os custos decorrentes do funcionamento do sistema e que surgem ao se utilizar o sistema de preços como mecanismo de alocação de recursos em ambientes que se afastam da concorrência perfeita.

Analisando-se as duas correntes complementares da NEI, observa-se que o ambiente institucional descrito por North (1990) é composto por normas e por formas das instituições no nível macro como, por exemplo, a Constituição Federal, o Sistema Judiciário, os direitos de propriedade, etc. Já Williamson (1985) trata das estruturas de governança e as define como as normas no nível micro, isto é, o regimento interno das empresas, os contratos estabelecidos entre as unidades econômicas, etc. O ambiente institucional, isto é, as regras gerais, é considerado como uma variável exógena e a forma de se organizar a produção é endógena, dentro do ambiente institucional.

Para tornar mais claro o detalhamento deste estudo, faz-se uma breve caracterização de alguns conceitos importantes. Apoiando-se em Williamson (1985), define-se firma como um conjunto de contratos que disciplinam as transações; estas são transformações de um produto por meio de interfaces tecnologicamente separáveis. Essa é uma visão contratual da firma que dispõe a transação como unidade analítica. Já, as instituições, segundo North (1990), são as regras que determinam como o jogo será operacionalizado e as organizações são os jogadores (atores), estabelecendo-se, desta forma, uma caracterização informal desses conceitos.

O mercado, para os economistas, é um conjunto de agentes (firmas ou indivíduos), cada um ofertando produtos ou serviços que têm algum grau de substituição para os mesmos compradores potenciais. Integração é um conceito bastante genérico, podendo ser caracterizado como: "a combinação de processos dentro das fronteiras de uma mesma empresa, ou seja, sob um mesmo comando decisório (seja um indivíduo, empresa, conglomerado, instituição ou outra forma), e que envolve a propriedade total dos ativos. É chamada de integração vertical quando esses processos são 
tecnologicamente distintos (ex: produção, processamento, distribuição, vendas) e integração horizontal quando não são distintos tecnologicamente. Pode ser nacional, quando está limitada aos limites do país, ou internacional (ou geográfica), quando a empresa integra-se em mais de um país”(Neves, 1995, p. 40). É, portanto, um termo utilizado quando uma empresa absorve uma parte ou completamente um processo, ou um elo de sua cadeia; por exemplo, quando as indústrias de laranja adquirem áreas para produzir laranja, ou uma indústria processadora de frango que tem a produção de frangos e de ração dentro da própria estrutura industrial. Neves (1995) discorre sobre as principais razões para ocorrer à integração vertical, que são: falha do mercado elevando os custos de transação; portanto, integra-se até o ponto em que os custos internos se igualam aos custos do mercado; interdependência tecnológica em operações tecnicamente encadeadas (como a produção de ferro e aço) e a integração das empresas por razões monopolísticas.

Neste trabalho buscou-se responder a algumas questões importantes: quais seriam os modos mais eficientes de se transacionar insumos e produtos? Como atuar no mercado ou realizar contratos verbais ou escritos? E ainda, como internalizar a produção? Essa escolha, segundo Williamson (1985), leva em conta a decisão entre: fazer - produzir sob estrutura hierárquica ou administração própria, comprar - usar o mercado; ou ainda, adotar formas híbridas entre os dois extremos. Normalmente, a escolha mais eficiente é a que minimiza os custos de produção e de transação, sempre lembrando que esses custos são distintos dentro de uma firma. A teoria exposta por Williamson (1985) - especificidade de ativos, incerteza e freqüência - tem sido utilizada na explicação das razões de decisões entre os tipos de negócios definidos na estrutura produtiva internacional, pois consegue completar pontos antes não explicados pela teoria ortodoxa, baseada no preço.

Neste estudo, a teoria desenvolvida por Oliver E. Williamson tem como pressupostos comportamentais a racionalidade limitada e o oportunismo dos agentes (empresários, produtores, pessoas envolvidas na atividade). A racionalidade limitada é 
decorrente da capacidade limitada dos agentes em absorver e processar as informações necessárias e pertinentes para a negociação, fazendo com que os contratos fiquem inevitavelmente incompletos.

Williamson (1985) relata que no oportunismo pressupõe-se que, em algum momento, os participantes adotarão comportamento oportunista, necessitando-se, desta forma, de salvaguardas contratuais. Esse comportamento pode ocorrer na fase précontratual - elaboração de contratos - ou na fase pós-contratual. Na elaboração dos contratos, os agentes geram, oportunisticamente, uma distorção - visão não real da situação de mercado, que neste caso, na fase pré-contratual, é conhecida como seleção adversa. Esta é considerada como um fator de risco nesta fase de negociação, cujo principal problema é a assimetria de informação, que faz uma das partes contratantes ter maior vantagem no momento anterior à vigência do contrato. Assim, a parte mais bem informada saberá se vale a pena ou não assinar o contrato. Já o risco pós-contratual é conhecido como moral hazard, que é o comportamento diferenciado para obtenção de vantagens de uma das partes, quando comparado àquele anterior à assinatura do contrato.

Neste estudo, a definição das estruturas mais eficientes de governança é o resultado entre os pressupostos comportamentais e as dimensões das transações. As transações diferem uma das outras e têm atributos distintos e observáveis na prática. Cada atributo representa uma dimensão da transação e o custo de transação é uma função no espaço n-dimensional, definido por estes atributos. Assim, as dimensões das transações contidas na Economia dos Custos de Transação (ECT) são três: especificidade de ativos (humanos ou físicos); incerteza e freqüência.

A especificidade dos ativos é caracterizada por aqueles ativos que não são reempregáveis em outras atividades, a não ser com perda de valor. Sendo assim, quanto maior a especificidade do ativo, maior será o custo de transação, porque, como o ativo só pode ser empregado numa atividade específica, e considerando-se que os agentes têm 
atitudes oportunísticas e os contratos são incompletos, é gerado um maior custo na transação. A especificidade pode ser locacional, física, humana, de marca, dedicada, temporal.

A especificidade locacional refere-se à distância entre as firmas de uma mesma cadeia produtiva, implicando em diferentes custos de armazenamento e transporte da produção. Na física, refere-se à especialização do ativo necessária para produzir o produto. Já a humana, como o próprio nome diz, relaciona-se à necessidade de investimento em capital humano para exercer a atividade. A especificidade de marca está mais ligada a investimentos feitos na marca do produto ou na empresa, principalmente nas franquias. Os ativos dedicados são os relacionados com os investimentos destinados aos clientes específicos, sem uso alternativo. E para finalizar, há a especificidade temporal, que se refere ao tempo em que a transação se processa, sendo importante em transações envolvendo produtos perecíveis. Então, quanto maior o nível de especificidade de um ativo, maior será a dependência entre as partes, impondo riscos adicionais e aumento nos custos dos processos de negociação e de monitoramento.

A segunda dimensão é a incerteza e está relacionada às dificuldades inesperadas encontradas nas transações, decorrentes do desconhecimento dos possíveis eventos futuros e do comportamento estratégico dos agentes envolvidos. Num ambiente de incerteza, as transações englobam contratos mais complexos, considerando-se que os agentes não conseguem prever e colocar tudo antecipadamente nos contratos porque estes têm racionalidade limitada. Assim, quanto mais incerto é o ambiente no qual se está transacionando, maior será o custo de transação envolvido.

A terceira dimensão é a freqüência das transações, que é a repetição de uma mesma espécie de transação. Tais transações podem ser: ocasionais - características pontuais (baixa repetição), ocorrendo, geralmente, via mercado - ou recorrentes quando os custos de negociação/contratos são diluídos entre as várias transações. 
Williamson (1985), ao detalhar o modelo para a escolha da forma organizacional, encontrou como variável chave à especificidade de ativos. Classificou, ainda, outras dimensões, ou o vetor parâmetro de deslocamento, como sendo a incerteza, a freqüência e o ambiente institucional. Ele estabelece uma função de custo de governança para cada estrutrura de governança, da seguinte ordem:

$\mathrm{m}(\mathrm{k}, \mathrm{q})$ - Custos de Governança de Mercado

x (k, q) - Custos de Governança Híbrida (Mercado e Hierárquica)

h (k, q) - Custos de Governança de Hierarquia (Integração Vertical)

Sendo, $\mathrm{k}=$ especificidade de ativos

$q=$ vetor parâmetro de deslocamento

Logo, como k (especificidade de ativos) é a variável chave, e para se encontrar a forma reduzida do modelo é preciso igualá-lo a zero (0) - $\mathrm{k}=0$-, obtendo-se:

$$
\mathrm{m}(0, \mathrm{q})<\mathrm{x}(0, \mathrm{q})<\mathrm{h}(0, \mathrm{q})
$$

Na equação 1 vê-se que o mercado tem custo menor de transação quando a especificidade de ativos (k) for igual a zero. Na mesma direção, pode-se construir uma nova forma para o modelo reduzido (na forma de equação e gráfico). Conforme $\mathrm{k}$ aumenta, os custos de se usar uma governança por meio do mercado, isto é, não internalizar a operação (governança de hierarquia) e nem realizar uma governança híbrida, aumentam mais que proporcionalmente ao das outras formas (Equação 2).

$$
\frac{\partial M}{\partial k}>\frac{\partial X}{\partial k}>\frac{\partial H}{\partial k}
$$




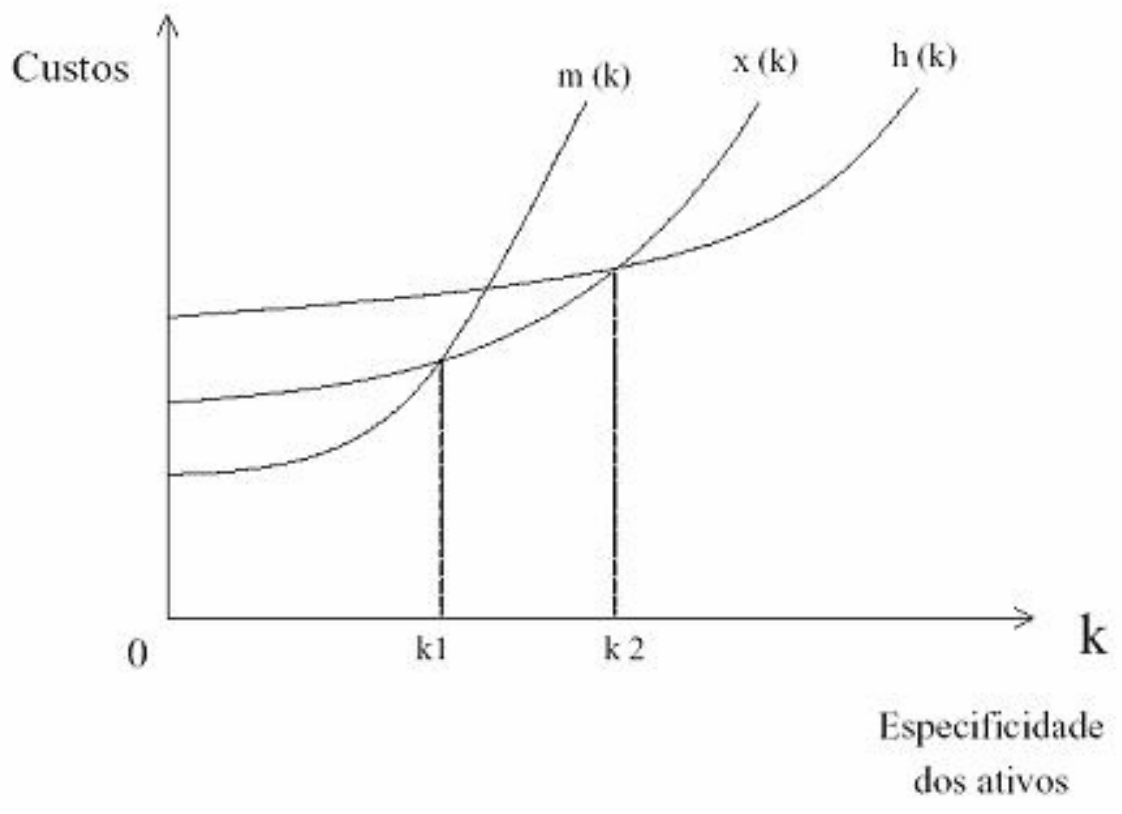

Figura 1 - Especificidade de ativos e mecanismos de governança. Fonte: Williamson (1985)

Na Figura 1, observa-se que no nível de especificidade k1, os agentes são indiferentes na escolha entre as formas organizacionais de mercado (m) e híbrida (x). No nível de especificidade k2, por sua vez, os agentes são indiferentes na escolha entre as formas organizacionais híbrida (x) e hierárquica (h). Assim, os agentes devem escolher a forma organizacional seguindo a especificidade de ativos; logo, dada uma especificidade $\mathrm{k}^{*}$, a forma organizacional escolhida deve ser: mercado $(\mathrm{m})$, se $\mathrm{k}^{*}<\mathrm{k} 1$; a forma híbrida (x), se k1 < $\mathrm{k}^{*}<\mathrm{k} 2$; e, hierárquica (h), se $\mathrm{k}^{*}>\mathrm{k} 2$.

Williamson (1985) argumenta que a indiferença entre as formas organizacionais pode se estender por uma área em torno dos pontos $\mathrm{k} 1 \mathrm{e} \mathrm{k} 2$, de tal modo que somente é seguro predizer que uma forma organizacional deva ser adotada quando a especificidade de ativos se afastar significativamente desses pontos. Essa proposição se sustenta no pressuposto comportamental de racionalidade limitada, impedindo os agentes de realizarem a separação clara entre as especificidades próximas. 
Desta forma, diante dos fatos observados pode-se dizer que a teoria científica é sustentada principalmente por Williamson (1985), que expõe a teoria sobre a Nova Economia das Instituições (NEI), trabalhando as instituições de governança baseadas na Economia dos Custos de Transação (ECT) e focalizado-se na parte microeconômica das cadeias produtivas; em seguida, North (1990), que também trabalha no contexto da teoria sobre a NEI; porém, diferentemente de Williamson (1985), que elabora o ambiente institucional focalizado-se na parte macroeconômica dos sistemas.

No Brasil, estudos referentes a NEI e ECT apontam para Zylberztajn (1995), que realiza estudo pioneiro relacionado à teoria das organizações empregadas no agronegócio (cadeias produtivas) e Azevedo (1996), que estuda a ECT aplicada à cadeia cítrica, assunto explorado neste trabalho.

Outros autores, como Besanko et al. (1996), descrevem quais são as fronteiras da verticalização e da integração vertical, principalmente as decisões "make or buy" (fazer ou comprar), como é conhecido o processo na literatura. A decisão da firma de produzir ela mesma ou comprar de um fornecedor independente é caracterizado pela decisão "make or buy". Esses autores apresentam as vantagens e desvantagens de cada procedimento apresentando exemplos aliados a referências teóricas/científicas na área. Os autores colocam apontam pontos relevantes no processo de "make or buy", e a existência de alguns paradigmas neste processo que são detalhados e refutados ao longo dessa discussão. Os autores listam, ainda, os três argumentos utilizados no mercado que justificam a decisão das firmas comprarem ou produzirem. Os argumentos seriam:

1. É preferível as empresas comprarem a produzirem, evitando, assim, os custos de produção do produto;

2. É preferível as empresas produzirem a comprarem, evitando, assim, pagar lucros para firmas independentes (prestadoras de serviços);

3. É preferível as empresas comprarem a produzirem, porque um produtor integrado verticalmente será capaz de evitar pagar preços de mercado 
mais elevados por insumos, durante os períodos de alta demanda e de baixa oferta.

Essas falácias são refutadas por Besanko et al. (1996) da seguinte maneira: a primeira é facilmente rejeitada, porque os custos de produção de um produto não são eliminados com a integração vertical, e a vantagem desse processo é o ganho de eficiência das firmas; o segundo argumento é rejeitado quando se considera o lucro que a empresa está proporcionando a esta prestadora não ser suficiente para remunerar o negócio, se todo o investimento for utilizado em treinamento e em expertize para a realização daquela atividade e, finalmente, a existência de contratos e/ou a utilização de mercados futuros permitem que os riscos das variações de preços sejam minimizados ou até mesmo eliminados.

No Quadro 1, os autores descrevem alguns benefícios e os custos que as empresas têm ao optarem pelo mercado, mostrando que em todo o processo de decisão sempre existirão os aspectos favoráveis/vantagens e os desfavoráveis/desvantagens, que devem ser analisados cuidadosamente. 


\begin{tabular}{|c|c|}
\hline \multicolumn{1}{|c|}{ Benefícios } \\
\hline$\checkmark$ & As firmas do mercado podem atingir economias de escala, enquanto que as \\
& integradas verticalmente produzem para o auto consumo; \\
$\checkmark$ & As firmas de mercado devem ser necessariamente eficientes e inovativas para \\
& sobreviver, pois são regidas pelas leis do mercado, enquanto que as integradas \\
& podem, na maioria, esconder ineficiências e falta de inovação nos processos. \\
\hline$\checkmark$ & A coordenação da produção, que flui através da cadeia verticalizada, deve estar \\
& muito mais comprometida quando uma atividade for comprada por uma firma \\
& independente em vez de ser realizada internamente; \\
$\checkmark$ & Informações privadas podem vazar quando uma atividade for exercida por uma \\
& firma de mercado independente; \\
$\checkmark$ & Alguns custos de transação com firmas independentes do mercado podem ser \\
& evitados se a atividade for realizada internamente.
\end{tabular}

Quadro 1 - Os benefícios e os custos que uma empresa/firma tem ao utilizar o mercado. Fonte: Besanko et al. (1996, p.112)

Ainda segundo os autores, o conceito de se comprar no mercado é derivado de outro extremamente simples: empresas do mercado são geralmente mais eficientes, podendo, por exemplo, desempenhar uma atividade com custos mais baixos e com qualidade maior do que o próprio comprador poderia apresentar. Por outro lado, o mercado possui três principais custos quando utiliza essa estratégia: os custos da frágil coordenação entre os degraus na cadeia de verticalização; a dificuldade e relutância de troca e desenvolvimento de informações valiosas entre os parceiros e, finalmente, os custos de transação das atividades.

Para Besanko et al. (1996), os problemas com os custos de coordenação e o vazamento/troca de informações são solucionados com contratos detalhados sobre essas questões. Os contratos seriam os elementos-chave numa economia de propriedade privada. Nessa filosofia estão incluídos importantes valores sociais, como a santidade 
das promessas, o direito dos indivíduos de entrar em transações anônimas e a eficiência econômica, que é mais profundamente analisada no estudo dos autores.

Segundo Besanko et al. (1996), os custos de transação compreendem dispêndios com tempo e gastos com negociação, e a escrita e cobrança (enforcing) dos contratos e são de difícil aplicação. O contrato se torna complicado quando são inseridos todos esses pontos importantes e necessários na sua elaboração e o acordo entre as partes não é estabelecido, evidenciando-se o oportunismo dos agentes. Os autores dividem os contratos em completos - os que eliminam o oportunismo, e os incompletos - que não mapeiam todos as contingências de direito das partes, elevando os custos de transação.

Os autores descrevem três pontos que dificultam os contratos completos: a racionalidade limitada, especificação e medição de desempenho, e a informação assimétrica, ficando, desta forma, bem próximos da teoria exposta por Williamson (1985).

Mais adiante, Besanko et al. (1996) discorrem sobre os custos de transação e sobre a integração vertical, evidenciando pontos de grande relevância que serão abordados neste trabalho. Eles afirmam que a possibilidade de se fazer um contrato com uma firma independente pode aumentar os custos de negociação e elaboração (escrita) dos contratos e pode aumentar os custos de produção. Para evitar isso, uma alternativa natural da empresa é a integração vertical. Assim, os autores admitem que a integração vertical pode ser preferível à troca por meio do mercado, elencando as três razões mais relacionadas à estrutura administrativa, adicionalmente à teoria de Williamson (1985): diferenças na governança, transações repetidas e influência organizacional.

Besanko et al. (1996) relatam ainda que a integração vertical permite o acesso parcial às estruturas de governanças mais fortes que as utilizadas pelas firmas de mercado. Isso facilita e permite a adaptação dos termos de uma transação quando as 
circunstâncias mudam ou quando as disputas aumentam. A principal diferença entre os tipos de governança dessas duas estruturas, mercado e integração, são os termos das relações de emprego e autoridade, normalmente os principais conflitos e problemas ocorrem. A integração facilita o gerenciamento por se caracterizar em transações repetidas com seu processo, apesar de, em alguns casos, existirem problemas de gerenciamento muito complexos. Caracterizando que, se as empresas forem parceiras, as tendências oportunísticas são minimizadas e há o aumento de cooperação entre elas.

Importante salientar que novas tecnologias facilitam o processo de decisão "Make or Buy", e está correlacionado com a eficiência do processo de produção, objetivo de grande importância para as empresas.

O trade off entre eficiência ${ }^{3}$ técnica $^{4}$ e gerencial ${ }^{5}$ será o ponto de decisão “Make or Buy”. Normalmente, a integração vertical é preferível à compra no mercado, sendo mais barato organizar as atividades internamente que organizá-las no mercado. E, essa diferença de custo é refletida nas duas eficiências, técnica e gerencial. Também será mais atrativa a integração vertical, quando a habilidade das firmas especialistas do mercado for limitada, quando comparada à firma internamente. Quanto maior for a escala operacional da firma e quanto mais específica for a transação de serviços e/ou produtos, mais favorável e próxima da integração vertical a empresa estará.

Besanko et al. (1996) descrevem pontos comuns com a teoria de Williamson e de outros autores da NEI, mas adicionam exemplos reais que interagem com a teoria, facilitando e engrandecendo sua contribuição para o estudo das formas de organização da produção e das decisões de terceirização da citricultura, porque, somente

\footnotetext{
${ }^{3}$ Eficiência é um conceito que se refere à realização de uma tarefa seguindo normas e padrões preestabelecidos. Sendo assim, no conceito de eficiência, examina-se se o produto ou o resultado do trabalho eficiente está adequado com a finalidade proposta (Sandroni, 2001)

${ }^{4}$ Eficiência Técnica: é o modo especial de se fazer alguma coisa que requer habilidade prática e conhecimento, do modo mais adequado possível, levando em conta os conhecimentos atuais (Sandroni, 2001)

${ }^{5}$ Eficiência Gerencial é a realização da forma mais adequada das funções de administração que envolvem planejamento, organização, direção e controle de uma atividade (Sandroni, 2001)
} 
com as aplicações práticas e reais a teoria se adere ao mundo real e consegue ganhar força e credibilidade entre os agentes dos setores econômicos.

No mesmo contexto, Brickley (2001) apresenta as maneiras de se gerenciar economicamente as diversas formas de organizações existentes nos modelos empresariais, encontrados nas indústrias, e não na agricultura. Neste trabalho, são detalhados desde os aspectos econômicos básicos (oferta e demanda) até os pontos mais complexos como a arquitetura das organizações e o modo como estão organizadas.

Brickley (2001) descreve que a terceirização envolve mudanças fundamentais na arquitetura das organizações, começando pela realocação dos aspectos decisórios de alguns pontos internos e de empregados entre uma firma e outra. Uma firma integrada verticalmente é aquela que participa em mais de um estágio sucessivo da cadeia vertical de produção. Essa integração vertical pode ser para frente ou para trás na cadeia. Quando o estágio de produção de matéria-prima faz integração com a indústria processadora define-se uma integração para frente na cadeia, e quando o estágio de produção faz integração com o produtor de insumos define-se a integração para trás.

O termo terceirização, para Brickley (2001), é freqüentemente utilizado para descrever movimentos que se distanciam da integração vertical - mover uma atividade para fora da firma que era feita anteriormente de modo formal pela própria empresa. Descreve, também, que é muito comum se pensar na terceirização como uma escolha contínua de possibilidades, desde a compra no mercado - Mercado Spot (onde as transações são feitas imediatamente ao preço corrente de mercado, sem relação de longo prazo entre as partes envolvidas) - até a empresa integrada verticalmente.

Brickley (2001) inicia a discussão sobre terceirização mostrando as vantagens de se transacionar no mercado. Segundo o autor, o mercado, teoricamente está em competição perfeita em alguns setores; se for competitivo, então se torna eficiente na produção e apresenta o menor custo médio possível. Logo, as firmas que comprarem no 
mercado poderão usufruir dessa vantagem de comprar produtos ou serviços de firmas altamente eficientes e que, na maioria dos casos, é um custo de aquisição mais barato para a firma, caso estivesse utilizando outro mecanismo de compra.

$\mathrm{O}$ autor relata, ainda, que o mercado consegue algumas vantagens porque alcança economia de escala, muitas vezes impossível de se conseguir quando se está produzindo ou operacionalizando um serviço interno na empresa. Outro fator é o custo de motivação, quando não se utiliza o mercado em algumas operações; isto é, o que ocorre quando as empresas se tornam extremamente grandes e não tão eficientes em certos setores e somente existem porque os setores mais rentáveis subsidiam-os.

Continuando, Brickley et al. (2001) argumenta contra a utilização de operações diferentes do mercado, porque os autores pregam que as empresas devem se concentrar no seu foco principal de negócio e contratar outros serviços e produtos complementares de firmas e distribuidores externos. Por sua vez, existem alguns fatores como custos de transação, regulação/taxas e poder de monopólio que fazem com que as firmas utilizem operações diferentes do mercado. Para a explicação dos custos de transação, o autor se apóia em Coase (1988), salientando que existem pelo menos quatro razões que podem fazer com que as transações não realizadas pelo mercado tenham preços inferiores aos encontrados no mercado spot, que são: especificidade de ativos da firma, custos de medição da qualidade, problemas de coordenação e externalidades.

Os autores destacam também a estratégia da empresa, isto é, existem alguns serviços e/ou produtos que mesmo sendo produzidos internamente, com custos mais dispendiosos, essa decisão "make or buy" acaba sendo tomada baseando-se na idéia de que, no mercado, o risco de oferta ou de não abastecimento dessa atividade específica é muito grande, dada a característica estratégica de seu setor, fazendo com que a empresa internalize essa atividade. 
Brickley (2001) relata que recentemente a terceirização de produtos e serviços está aumentando, devido, primeiramente, à correção de investimentos mal feitos no passado; e, em segundo plano, à utilização de uma tecnologia de produção mais flexível, facilitando a adaptação dos fornecedores às mudanças dos seus clientes. Finalmente, os avanços em tecnologia de informação e comunicação facilitam o encontro de potenciais parceiros. Esses movimentos de terceirização, porém, não mudam completamente a estrutura das empresas; apenas os operacionalizam em alguns segmentos de sua organização.

Neves (1995, p.48) define terceirização ("outsourcing") como: "um processo de transferir etapas inseridas no mesmo comando decisório, dentro das fronteiras de uma mesma empresa, para terceiros, ou seja, "des-integração" vertical ou horizontal. Retira-se determinada etapa da estrutura hierárquica da empresa e passa-se a obter os insumos, produtos ou serviços do mercado ou via contratual". Evidencia que no processo de terceirização, a empresa tem como principal objetivo a concentração de seus esforços nas atividades que sabem fazer melhor, isto é, possuem vantagens competitivas.

Para o SEBRAE (1999) o processo de terceirização é uma estratégia adotada por grandes empresas com estruturas complexas. Consiste em repassarem suas tarefas secundárias a pequenas empresas especializadas, para poder realizar melhor sua atividade principal. A terceirização é um processo que melhora a qualidade dos produtos e serviços das empresas envolvendo menores custos.

Comumente, as empresas terceirizadas nascem da própria estrutura da grande empresa, que converte seus funcionários em novos empresários. A terceirização não se limita à geração espontânea de empresas a partir de uma "empresa-mãe", qualquer empresa que esteja atenta às oportunidades do mercado e assuma uma postura gerencial adequada ao processo pode prestar serviços ou vender para terceiros. Para isso, é preciso que tenha uma estrutura moderna e, ainda, que desenvolva qualidade, competitividade e aprimoramento do senso de parceria, além de visão em longo prazo. 
São considerados como aspectos positivos da terceirização:

$\checkmark$ diminuição do desperdício de produtos;

$\checkmark$ aumento da qualidade dos produtos;

$\checkmark$ desmobilização das atividades;

$\checkmark$ integração da empresa na comunidade;

$\checkmark$ melhoria do perfil do administrador;

$\checkmark$ diminuição da corrupção interna e externa;

$\checkmark$ diminuição do poder político interno e externo;

$\checkmark$ aumento da especialização/lucro;

$\checkmark$ favorecimento da economia de mercado;

$\checkmark$ liberação da criatividade dos funcionários;

$\checkmark$ otimização dos serviços;

$\checkmark$ soma da qualidade na atividade-meio e na atividade-fim;

$\checkmark$ melhoria da administração do tempo da empresa;

$\checkmark$ aumento do comprometimento da comunidade com a empresa e do público interno da empresa;

$\checkmark$ melhoria na imagem institucional da empresa;

$\checkmark$ criação de empregos e empresas mais estáveis;

$\checkmark$ aumento da agilidade da organização;

$\checkmark$ aumento de empregos especializados e da competitividade da empresa.

Por sua vez, são tidos como aspectos negativos da terceirização:

$\checkmark$ aumento do risco a ser administrado;

$\checkmark$ dificuldade de aproveitamento dos empregados já treinados;

$\checkmark$ demissões na fase inicial da atividade tercerizada;

$\checkmark$ mudança na estrutura do poder da empresa;

$\checkmark$ falta de parâmetros de preço nas contratações iniciais;

$\checkmark$ alto custo das demissões;

$\checkmark$ má escolha de parceiros;

$\checkmark$ má administração do processo mudança de estrutura da empresa; 
$\checkmark$ aumento da dependência de serviços e produtos de terceiros.

No Brasil, segundo o SEBRAE (1999), não há legislação específica sobre a terceirização. As leis protegem os trabalhadores contra as fraudes e isso dificulta a difusão da própria legislação. Por isso, é preciso se reportar aos conceitos de empregado e empregador para que se elaborem, por exclusão, os limites jurídicotrabalhistas da chamada relação de terceirização.

\subsection{Metodologia}

\subsubsection{Método}

Para alcançar os objetivos propostos, a metodologia do presente estudo se apóia em Malhotra (2001), que descreve os procedimentos aplicados para a realização de uma pesquisa. $\mathrm{O}$ autor apresenta em seu estudo as formas de levantamento de dados (primários e/ou secundários) visando solucionar problemas ou buscar novas informações. É instrumental descritivo que apresenta as vantagens e desvantagens de cada procedimento, bem como sua conceituação teórica/científica. Na figura 2 estão descritos os procedimentos sugeridos por Malhotra (2001).

O autor faz a divisão dos dados de pesquisa em primários ou secundários. Quando primários, os dados podem ser obtidos na forma qualitativa ou quantitativa. $\mathrm{Na}$ forma quantitativa podem ser descritivos ou causais. Os descritivos são provenientes de survey (amostra) ou de dados observacionais e outros; por sua vez, o causal é obtido por meio de dados experimentais. 


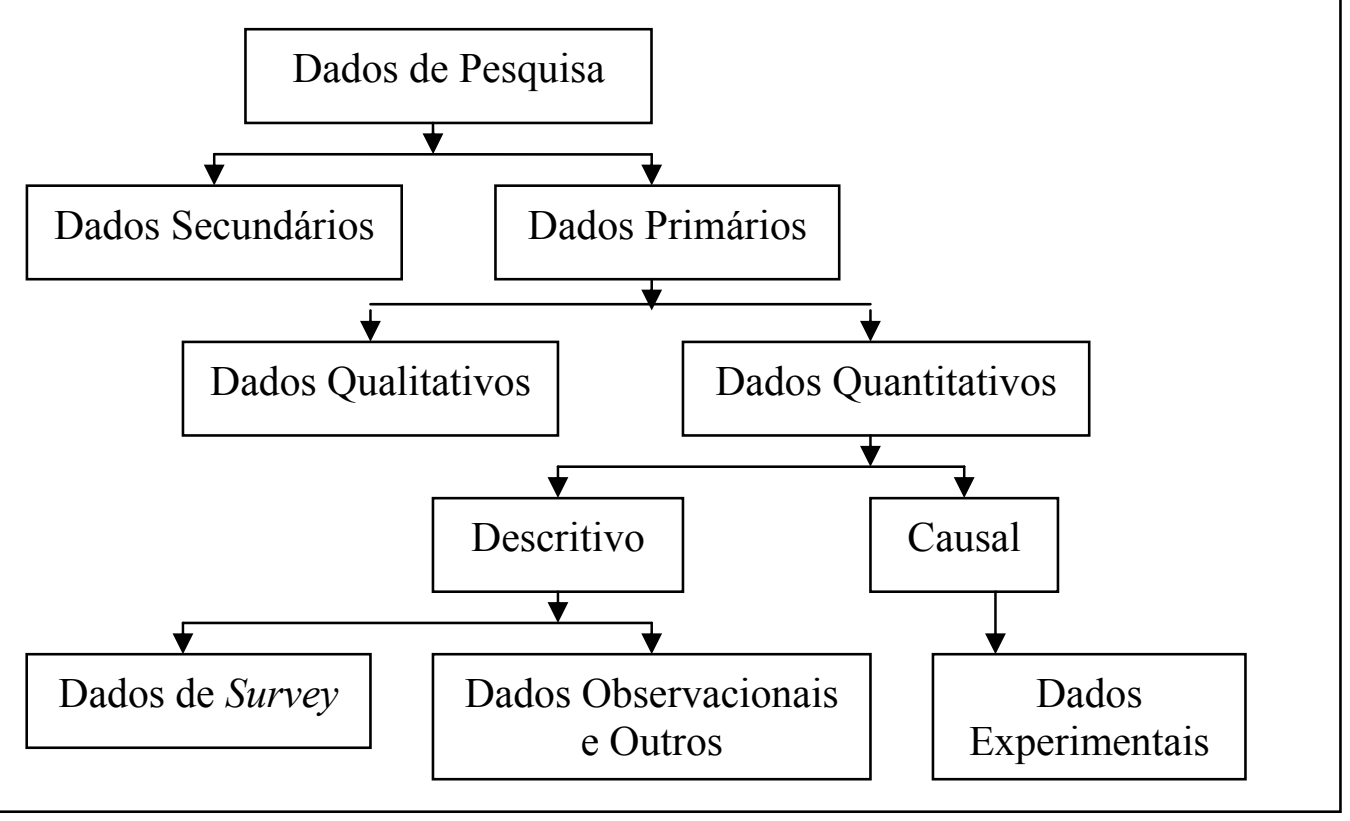

Figura 2 - Classificação de dados de pesquisa.

Fonte: Malhotra (2001)

Dados primários são aqueles gerados por um pesquisador para a finalidade específica de solucionar o problema. A coleta desses dados envolve todas as etapas do processo de pesquisa, que são: definição do problema, elaboração de uma abordagem do problema, concepção da pesquisa, trabalho de campo ou coleta de dados, preparação e análise dos dados e a preparação e apresentação do relatório conforme mostrado na Figura 2. Normalmente a obtenção dos dados é dispendiosa e demorada (Malhotra, 2001).

Já os dados secundários são coletados para objetivos que não os do problema em pauta. Podem ser localizados de forma rápida e barata em bibliotecas, centros de pesquisa ou mesmo na internet (Malhotra, 2001).

Indicando as diferenças entre dados primários e secundários, Malhotra (2001) mostra que o uso dos dados secundários pode levar alguma vantagem e 
apresentar usos distintos quando comparados com os primários. Por exemplo, os dados primários são originados pelo pesquisador com a finalidade específica de solucionar um determinado o problema; por sua vez, os secundários são coletados com finalidades diferentes daquelas do estudo em questão. Os dados secundários são coletados de maneira fácil e rápida, com custo de obtenção relativamente baixo e tempo de coleta curto, mas não proporciona um contato direto com a fonte, podendo não ser exato ou viesado. Já os dados primários são provenientes da fonte, são dados coletados face a face de modo mais lento, com custo de obtenção relativamente alto e tempo de coleta longo.

Para Malhotra (2001) tem-se dentro dos dados primários, dois tipos de pesquisa que podem ser utilizados: qualitativa e quantitativa. Com a qualitativa, o objetivo é alcançar uma compreensão qualitativa das razões e motivações subjacentes à problemática principal do estudo por meio de uma amostra com pequeno número de casos não-representativos por meio de uma metodologia de pesquisa não-estruturada e explanatória. Como resultado, a análise dos dados não é estatística, pois se desenvolve uma compreensão do contexto do problema. Já o levantamento quantitativo tem como objetivo quantificar os dados e informações e generalizar os resultados da amostra para a população-alvo, se valendo, como amostra, de um grande número de casos representativos, com coleta estruturada de dados. Apresenta-se uma análise estatística de dados e obtém-se, como resultado, uma recomendação de curso final de ação.

Para os objetivos apontados neste estudo, a pesquisa qualitativa é a mais apropriada, abrindo espaço para outros estudos exploratórios que empregam tipos específicos de pesquisa quantitativa.

A Figura 3 ilustra o processo de pesquisa qualitativa como um todo, mas salienta-se que este estudo se insere apenas no tópico direto (não-simulado) e em entrevistas de profundidade. 


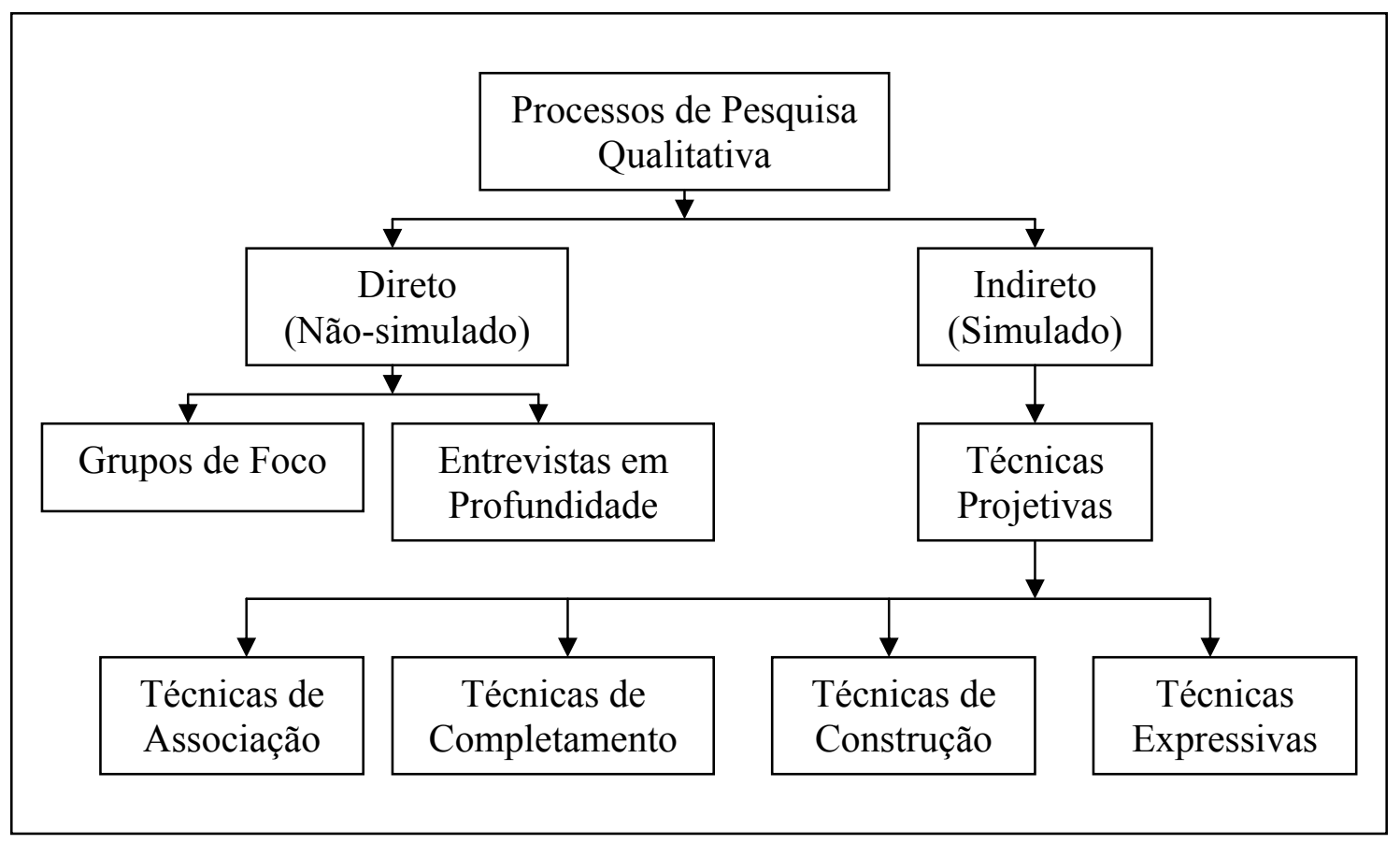

Figura 3 - Classificação dos processos de uma pesquisa qualitativa.

Fonte: Malhotra (2001)

Malhotra (2001) descreve como sendo método de pesquisa qualitativo direto, não-simulado, quando a abordagem não for disfarçada, o objetivo do projeto é revelado aos entrevistados ou conhecido por eles pelas próprias questões formuladas. Já no método indireto, os objetivos são disfarçados não se revelando aos entrevistados o real objetivo da entrevista.

Dentro do método direto as mais importantes técnicas utilizadas são: os grupos de foco e as entrevistas em profundidade. Os grupos de foco apresentam um tamanho variável de 8 a 10 pessoas relacionadas com o setor, sendo relativamente homogêneos e os respondentes são pré-selecionados. No contexto físico, é caracterizado por um ambiente relaxado e informal que normalmente tem duração de 1 a 3 horas. São utilizados recursos audiovisuais para o registro do encontro e o moderador deve ter habilidades observacionais, interpessoais e de comunicação. Como vantagens, o grupo de foco apresenta, além do sinergismo, um grupo de pessoas que produz um maior 
âmbito de informações, com visão mais aprofundada, quando reunidas. Este, também, gera a conhecida estratégia "bola-de-neve", em que comentários de outras pessoas criam uma reação em cadeia dos outros participantes favorecendo a discussão. Além destes, existe o estímulo de expressar suas idéias quando as pessoas são colocadas em platéia, tem mais segurança de expressão quando as opiniões e idéias convergem entre os participantes, deixando-os mais confiantes em dar contribuições, facilitando a espontaneidade e a estrutura da reunião, etc.

Já as entrevistas em profundidade são realizadas uma a uma. Trata-se de uma entrevista não-estruturada, direta, pessoal, em que um entrevistado de cada vez se reúne com um entrevistador altamente qualificado para discutirem um determinado tópico. O entrevistado deve revelar suas motivações, crenças, atitudes e sentimentos em relação ao tópico abordado. Pode levar de 30 minutos à uma hora. Outro aspecto interessante é que mesmo se o entrevistador tentar seguir um esquema pré-determinado de questões, ficará ainda sujeito ao andamento da conversa, bastando apenas uma resposta diferente ou discrepante para que o roteiro seja mudado.

Entre as vantagens das entrevistas em profundidade está a capacidade de revelar análises pessoais mais aprofundadas que nos grupos de foco; por outro lado, dificulta a exposição das informações coletadas, porque é possível atribuir as respostas diretamente ao entrevistado de forma diferente do que ocorre no grupo de foco, pois é difícil ligar as respostas aos entrevistados. Outra vantagem das entrevistas em profundidade é a livre troca de informações, sem pressão social. Apresenta algumas desvantagens, como a necessidade de se ter um entrevistador habilidoso, cada vez mais raro no mercado. A falta de rigidez de roteiro torna os resultados susceptíveis à influência do entrevistador.

Para a finalidade deste estudo a melhor alternativa dentre as propostas por Malhotra (2001) é a entrevista em profundidade, que busca retirar do entrevistado, de 
forma individual, suas sensações, sentimentos, atitudes e valores e revelar os aspectos da cultura organizacional na qual está inserido.

\subsubsection{Material}

Como ponto de partida este estudo se apoiou em um levantamento bibliográfico feito em bibliotecas, sites e bancos de dados com a finalidade de se encontrar material de base técnica e/ou científica sobre a maneira como estão organizadas os produtores da indústria cítrica de São Paulo (Brasil) e da Flórida (EUA). Buscou-se ainda dados sobre decisões de terceirização na produção cítrica paulista visando atender os dois objetivos propostos. Breve discussão sobre organização industrial, formas de organizações e arquitetura das organizações também foram pesquisados com a finalidade de interligar a base teórica e científica com os métodos e tipos de organizações desenvolvidas no negócio de produção de laranja.

A coleta dos dados, para traçar os modelos de negócios encontrados na citricultura do Brasil e dos EUA é baseada num levantamento original (dados primários - pesquisa qualitativa), conduzido por meio de entrevistas feitas em processo direto (não simulado) e, em profundidade, com pessoas de diferentes organizações, relacionadas com estudos, pesquisas e negociação da produção cítrica das duas regiões. A amostra usada no trabalho foi, intencionalmente, selecionada com a ajuda de pesquisadores e especialistas, de instituições públicas e privadas, ligados ao negócio cítrico. Foram incluídas pessoas associadas a diferentes tipos de organizações, inseridas dentro do negócio cítrico, tanto no Brasil como nos EUA (empresas privadas, públicas, grandes e pequenas, investidores, entidades nacionais e internacionais). As questões utilizadas na pesquisa estão apresentadas no Anexo A. Também está o roteiro utilizado nas entrevistas para a obtenção das características dos tipos de negócios de cada região produtora. As questões foram direcionadas e conduzidas para que o entrevistado listasse os pontos chaves de cada estrutura de negócio e suas características positivas e negativas. 
No Brasil, as entrevistas foram realizadas no período de 25 de fevereiro a 18 de julho de 2003 e incluíram os principais representantes do sistema agroindustrial cítrico do Estado de São Paulo e estudiosos do assunto. Para a delimitação do negócio cítrico dos $\mathrm{EUA}^{6}$, foram realizadas entrevistas na Flórida, nos meses de outubro e novembro de 2001, detalhando os tipos de negócio existentes na citricultura do estado norte-americano e utilizando fontes de dados primários considerando-se as principais regiões produtoras. Além dos dados já publicados, foram acrescentados outros colhidos na Flórida, que ainda não tinham sido analisados no trabalho citado.

Nos Quadros 2 e 3, estão caracterizados as organizações e os tipos de negócios visitados e o número de entrevistados. Estão divididos segundo as estruturas de negócios que serão descritas no decorrer das seções seguintes. Os agentes entrevistados, das regiões estudadas, estão relacionados nos Anexos B e C.

\footnotetext{
${ }^{6}$ Parte dos resultados já foi publicado em DRAGONE et al. (2002).
} 


\begin{tabular}{|l|c|}
\hline Estrutura de Negócio & Número de Visitas \\
\hline Owners (Produtores) & 2 \\
\hline Absentee (Investidores) & 2 \\
\hline Cooperativas & 2 \\
\hline Firmas de Gerência \& Investimento & 6 \\
\hline Caretakers (Terceirizadores) & 2 \\
\hline Empresas & 5 \\
\hline Associações & 1 \\
\hline TOTAL & $\mathbf{2 0}$ \\
\hline
\end{tabular}

Quadro 2 - Entrevistas desenvolvidas por categorias de estruturas de negócio na Flórida. Fonte: Dragone et al. (2002)

\begin{tabular}{|l|c|}
\hline Estrutura de Negócio & Número de Visitas \\
\hline Produtores & 2 \\
\hline Cooperativas & 1 \\
\hline Empresas e Sociedades & 2 \\
\hline Instituições de Pesquisa & 4 \\
\hline Associações e "Pools" & 4 \\
\hline TOTAL & $\mathbf{1 3}$ \\
\hline
\end{tabular}

Quadro 3 - Entrevistas desenvolvidas por categorias de estruturas de negócio em São Paulo.

Fonte: Dados de pesquisa feita entre fevereiro e julho de 2003.

Os dados e informações obtidos são comparados para a delimitação das semelhanças e diferenças entre os dois modelos, dos quais se obtém parâmetros para definir os principais problemas de cada um. 


\section{REVISÃO DE LITERATURA}

Nesta seção, de forma cronológica, e com breve descrição, estão relatados alguns estudos a fim de reforçar e facilitar comparações com a presente pesquisa, principalmente relacionados a aspectos da produção cítrica ou tópicos não descritos no arcabouço teórico.

Rodriguez et al. (1987) mostram um panorama geral da citricultura brasileira desde os primórdios até o início da década de 90, relatando brevemente aspectos econômicos e se aprofundando no aspecto técnico da citricultura. Os autores concluem que a citricultura brasileira tem uma ótima tecnologia de produção, mas que vários aspectos técnicos importantes devem ser considerados a fim de incrementar a eficiência da gestão de negócios futuros. O trabalho desses autores é importante para a caracterização histórica do setor e para delimitar as principais práticas culturais que eram e são utilizadas na citricultura brasileira. Isto acaba evidenciando as potenciais técnicas culturais sujeitas à terceirização, bem como as que podem ser limitantes no processo.

Bialoskorski (1994) descreve que o cooperativismo oferece ao produtor rural uma grande vantagem, pois este tipo de organização aumenta o seu nível de renda, agregando economias particulares, ganhos de escala e beneficiando transações ao longo da cadeia agroindustrial.

Muraro et al. (1994) desenvolveram uma pesquisa que compara os custos de produção da citricultura no Brasil, nos Estados Unidos, na Argentina, no Uruguai e no México, onde são trabalhadas taxas de retorno e custos de produção para cada uma 
das regiões, estabelecendo um padrão de custos de produção com planilhas muito detalhadas, fator que facilita a caracterização das operações técnicas utilizadas nesses países e as principais diferenças entre eles. Este estudo coloca os valores de custo de produção e ganhos/receitas de cada forma de organização existente nas regiões produtoras de laranja, fazendo, assim, uma caracterização de receita aproximada para a atividade, mostrando as vantagens e desvantagens de cada estrutura organizacional e caracterizando no ciclo de produção as possibilidades de negócios e o envolvimento de diferentes agentes econômicos, de acordo com a estacionalidade da produção e dos tratos culturais.

Neves (1996) relata em seu estudo a competitividade da agroindústria cítrica brasileira, apontando as vantagens comparativas e os dilemas das barreiras comerciais. Torna-se, portanto, uma importante fonte de teoria científica aplicada diretamente na cadeia estudada neste trabalho. $\mathrm{O}$ autor ainda relata algumas diferenças $\mathrm{e}$ similaridades entre os tipos de estrutura produtiva nas citriculturas de São Paulo e da Flórida, reforçando as características e descrições expostas neste estudo.

Alguns estudos recentes detalham certos aspectos de relevância na abordagem comportamental e cultural da citricultura, como o de Viega et al. (1996), que é um estudo descritivo sobre o trabalho dos colhedores de laranja no estado de São Paulo e as principais mudanças contratuais (principalmente cooperativas) que estão sendo planejadas para este segmento, facilitando o entendimento sobre esta importante etapa no processo produtivo da laranja.

Fasulo (1998) descreve todas as organizações existentes na citricultura da Flórida, aglomeradas num banco de dados, relatando número e localização destas, desenvolvendo um papel primordial na seleção e no contato com os agentes do setor, entrevistados na Flórida, os quais favoreceram indicações para as formas de organização e as relações existentes entre os agentes da cadeia cítrica, no estado norte-americano. 
Baptistella et al. (1999) descrevem os colhedores na agroindústria da laranja no Estado de São Paulo levando em conta, predominantemente, aspectos sociológicos e também um histórico descritivo de como a colheita de laranja era realizada antes da reorganização do setor, em 1994, indicando a situação atual e as possibilidades futuras deste segmento da cadeia produtiva da laranja, em relação à colheita manual de frutas.

Spreen et al. (1999) apresentam um panorama da citricultura da Flórida citando dimensões organizacionais, favorecendo uma visualização econômica abrangente da citricultura daquele estado americano. Amaro et al. (2000) relataram aspectos da citricultura paulista e evidenciam a tecnologia e a mão-de-obra apresentando dados sobre a distribuição das áreas no estado e alguns aspectos históricos.

No tópico que relaciona investimentos e formas de administração de negócios agrícolas, o estudo de Wise (1993) é direcionado para o investimento em agricultura nos Estados Unidos, abrangendo aspectos teóricos e práticos gerais. Mostra todos os aspectos fortes e fracos sobre esse tipo de investimento e porque considera o negócio promissor em futuro próximo. Descreve, ainda, a importância deste tópico na economia estadounidense e a grande ênfase dada ao investimento em agricultura como uma opção interessante para todos investidores e com significativos ganhos financeiros.

O estudo de Wise (1993) aponta também, um importante aspecto da comparação entre dois portifólios de ações, um agregando a agricultura e outro não. O marcante é que o portifólio com agricultura apresenta uma curva de retornos versus desvio padrão bem mais interessante para os investidores, porque apresenta numa mesma faixa de desvio padrão um retorno superior, ao ser comparado com o outro portifólio.

A Figura 4 ilustra a vantagem de se absorver investimentos relacionados na agricultura nos portifólios de investimentos em estudo apoiado no trabalho de Lins (Universidade de Illinois), e citado por Wise (1993). Nesse estudo, o autor compara dois 
tipos de portifólios de ações compostos por títulos de tradicionais do mercado de investimento, mas com uma única diferença, a adição ou não de títulos da agricultura, formando os portifólios com e sem agricultura. Assim, observa-se na figura 6 que, considerando um mesmo nível de risco (desvio padrão), o portifólio com agricultura apresenta um maior retorno médio anual no período do estudo.

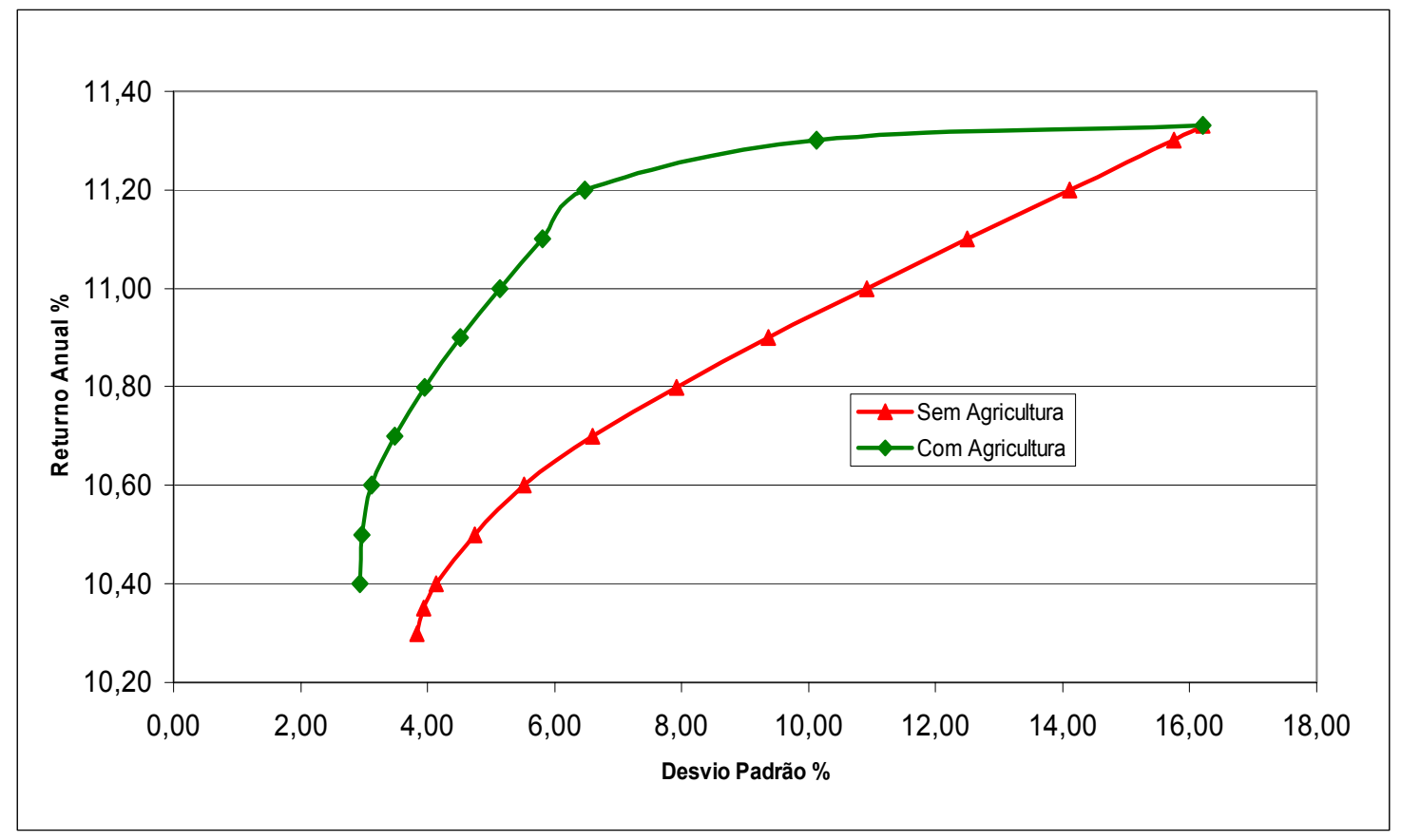

Figura 4 - Comparação entre dois portifólios de ações de 1970-1990.

Fonte: Wise (1993)

Lins cita ainda em seu estudo Morgan Stanley (1990), que contabilizou os retornos médios e desvios padrões de diversos investimentos do mercado de capital, mostrando principalmente o desempenho da agricultura norte americana, quando comparado com o de outros tipos de investimentos, no período de 1940 a 1990, evidenciando a característica de os americanos investirem em agricultura e a demanda existente desde a década de 40 por investimentos que tenham ligação com a agricultura. 
Amaro et al. (2000) relatam em seu trabalho as estruturas de produção nas áreas de produção cítrica do Estado de São Paulo, focando aspectos sociais e técnicos. Os autores relatam aspectos sociais do setor, como a escolaridade do homem do campo, o tipo de da atividade que exerce etc. Tais aspectos são relevantes para o presente estudo, porque os aspectos sociais não foram abordados diretamente, além de fornecerem indicações sobre a aversão a risco, o não conhecimento dos instrumentos financeiros por parte dos agricultores diante do quadro cultural regional e prevalecente no interior agrícola: baixa instrução da população agrária.

Barros et al. (2002) descrevem em seu estudo a existência de crédito para custeio e investimento no setor hortifrutigranjeiro brasileiro. Mostram que existem desigualdades dentro das cadeias produtivas (algumas culturas são favorecidas), e que os produtores estão buscando e encontrando outras formas de capitalização diferente do modo de obtenção tradicional, via bancos públicos. Crédito é um aspecto relevante para este estudo, principalmente quando se discute as potencialidades e limitações da terceirização da produção cítrica no Estado de São Paulo.

Dragone et al. (2002) tratam da descrição dos tipos de investimento existentes na citricultura da Flórida (EUA), estabelecendo comparações e perspectivas para estes tipos de negócios no Brasil, fazendo uma primeira descrição das formas de organização do setor naquela região e sendo uma das principais referências para o estudo. Neste estudo, os autores ficaram restritos às formas de organização existentes na citricultura da Flórida e apresentaram somente alguns detalhes comparativos com a citricultura do Estado de São Paulo. Além disso, o aprofundamento teórico dos tópicos é superficial, considerando-se a literatura que cita as formas de organização e as decisões sobre a aplicação da terceirização tomada pelos produtores/empresários na citricultura brasileira e estadounidense. Diante de tais limitações, este estudo serve de ponto de partida para esta pesquisa que visa completamentar as descrições sobre os agentes econômicos do setor cítrico paulista. 
Com o reforço das seções anteriores descrevendo os aspectos importantes da cadeia estudada e os pontos relevantes na literatura científica têm-se, a seguir, os resultados deste estudo seguindo seus dois objetivos. Primeiramente, a caracterização das formas de organização de cada região produtora de citros e, segundo a análise de decisão de terceirização na citricultura. 


\section{RESULTADOS}

\subsection{Formas de organização da produção: Brasil e EUA}

Nesta seção é estabelecida a caracterização dos tipos de negócios ${ }^{7}$ existentes na citricultura do Estado de São Paulo (Brasil) e do Estado da Flórida (EUA), com alguns detalhes técnicos e econômicos que facilitam a apresentação de cada modelo utilizado nas regiões produtoras e a compreensão da importância do estudo para as duas citriculturas. Os dados foram obtidos via entrevistas, feitas em diferentes períodos (Outubro/Novembro de 2001 na Flórida, e Fevereiro/Julho de 2003 em São Paulo) nas regiões produtoras de citros.

\subsubsection{Formas de organizações encontradas na Flórida (EUA)}

Os resultados obtidos nesta pesquisa facilitam o detalhamento da estrutura de negócios existente na citricultura da Flórida - setor da produção de matériaprima. Tal estrutura é tratada, de forma sucinta, nesta seção, e foram incorporados outras informações, extraídas das entrevistas originais com os produtores da Flórida.

É importante realçar que algumas das relações descritas nas formas de organização encontradas na Flórida não foram traduzidas para a língua portuguesa para

\footnotetext{
${ }^{7} \mathrm{O}$ trabalho utilizou diversas informações sobre as formas de investimento na citricultura da Flórida contidas nos prospectos institucionais da American Agronomics Corporation (1968 e 1971), empresa de investimento e gerenciamento.
} 
não descaracterizá-las e para facilitar a ligação entre o texto e a realidade da região, vis a vis, com a usual utilização desses termos no cotidiano do setor cítrico.

Os principais tipos de negócios de investimento e de administração da produção presentes na citricultura da Flórida são os seguintes:

\subsubsection{1 “Growers” (Produtores)}

No modelo da citricultura do Estado da Flórida, existem dois tipos de negócios que utilizam dessa mesma denominação: os "growers", proprietários dos pomares que são detentores de todos os ativos fixos empregados, e os "growers" proprietários de pomares que em função do tamanho de área, podem terceirizar alguns serviços.

Os "Growers" são os efetivos produtores agrícolas. Seu negócio é familiar, isto é, toda a família está envolvida na atividade de produção. Os "growers" são os próprios donos do negócio, possuindo, na maioria, grandes faixas de terra com áreas superiores a 400 ha. Os serviços não são terceirizados porque toda a infraestrutura (máquinas, implementos, etc.) relacionada com as atividades necessárias ao pomar já está incorporada. Isso só é possível e viável economicamente devido aos ganhos de escala associados aos tamanho e à produção dessas propriedades. O gerenciamento das atividades no negócio é feito pelos próprios proprietários ou por consultores privados, contratados para esse serviço específico; assim, conseguem tomar todas as decisões sobre a produção (pulverizações, fertilizantes, venda de frutas). Na busca de financiamento bancário ou governamental, a incerteza fica associada ao produtor, em relação a seus bens patrimoniais e ao capital, mesmo sabendo que utilizam ferramentas governamentais de grande importância, como o seguro agrícola. Com produção em larga escala, a negociação com os agentes pós-porteira na cadeia torna-se mais fácil/eficaz, gerando, assim, contratos próprios com as indústrias processadoras. 
O segundo tipo de "Growers" é composto por terceirizadores de serviços, com bastante similar ao anterior, mas com algumas peculiaridades. Continuam sendo negócios totalmente familiares, tendo como donos do negócio os próprios produtores. $\mathrm{Na}$ maioria, possuem áreas médias que variam de 40 ha a 400 ha, já entrando numa escala em que alguns serviços podem ser terceirizados, tais como pulverizações e colheitas. Possuem apenas parte do maquinário (menor capital investido), trabalhando somente com os serviços mais específicos e estratégicos. No gerenciamento, algumas vezes podem decidir e/ou contratar consultoria (caretakers ou consultores). Continuam sendo o principal captador e avalista de financiamentos e investimentos para o seu próprio negócio. Esse tipo de empreendedor consegue estabelecer uma relação mais equilibrada com as indústrias, já que, por ser de tamanho mediano, as relações com as indústrias ainda são facilitadas pelo quantidade de matéria-prima produzida.

\subsubsection{2 “Absentee owners” (Proprietários ausentes)}

Os "Absentee owners" são os investidores não-relacionados diretamente com agricultura, não sendo seu principal negócio; geralmente são proprietários de restaurantes, lojas comerciais, etc. Encontram-se nesse tipo de atividade profissionais liberais, professores universitários e pessoas com raízes urbanas que, nesse caso, são os donos do negócio; isto é, possuem uma área de terra e nenhum conhecimento sobre produção cítrica, mas gostariam de investir na atividade. "Absentee" significa, para os integrantes do negócio cítrico da Flórida, pessoas que são de fora do Estado. Esse tipo de produtor/dono da terra foi se estabelecendo com a migração vindo do norte dos EUA para o sul, no inverno. Assim, essas pessoas vinham com suas famílias para a Flórida e gostavam de ser produtores de laranja no Estado; desta forma, sentem-se atualmente orgulhosos em dizer que possuíam terras e ainda que produzem laranja.

Freqüentemente as áreas utilizadas pelos "absentee owners"são pequenas, inferiores a 40 ha. Os "absentee owners" não possuem conhecimento para o negócio e 
desconhecem as técnicas empregadas em atividades agrícolas; então, acabam terceirizando todo o serviço na propriedade. A propriedade não apresenta estrutura de gerenciamento, e não possuem maquinário próprio. As decisões técnicas são comumente tomadas por consultores e somente, algumas vezes, pelo próprio dono.

O financiamento para custeio e investimento da atividade é obtido mais facilmente, porque os proprietários não têm como principal atividade a agricultura; o capital vem, então, de outras fontes, facilitando a capitalização em anos de crise. Os contratos com as indústrias ficam complicados devido à baixa escala de produção dessas áreas, mas os proprietários ausentes podem ter ou não contratos próprios com as indústrias. Quando não possuem contratos privados, eles acabam utilizando-se de firmas de comercialização ou cooperativas para vender seus produtos.

\subsubsection{3 “Caretakers” (Empresas prestadoras de serviços)}

O "Caretaker" é um tipo de negócio privado ou familiar. Essas empresas são responsáveis pelo gerenciamento de propriedades agrícolas. Fazendo um comparativo com o Brasil, são as empresas prestadoras de serviços, as que assumem os serviços terceirizados por uma propriedade. Assim, são empresas contratadas pelos produtores para administrar suas terras e que possuem toda a infraestrutura necessária para a realização das atividades dentro da fazenda. Estão localizadas em regiões estratégicas dentro do pólo produtor de laranja, onde seu raio de atuação nunca excede $50 \mathrm{Km}$, para não dificultar a logística de seus equipamentos.

Nas entrevistas, os executivos dessas firmas afirmavam que podiam rapidamente aplicar um defensivo em toda a sua área de atuação; em média, 15 dias era o tempo gasto para a realização dos tratos culturais em seus clientes. Tais firmas terceirizadoras utilizam seus consultores para auxiliar suas operações, mas estes não podem tomar todas as decisões na propriedade, devendo contatar os produtores para decidir. Isso porque as prestadoras têm um custo mensal que é cobrado de seus clientes 
(antes ou depois da realização das operações) e nada pode ser feito sem que todos os detalhes estejam acordados previamente entre as partes. Os valores considerados, normalmente, são os custos de aplicação dos produtos (herbicidas, defensivos) ou do serviço prestado naquela propriedade, mais os custos administrativos, que são em torno de $10 \%$ do total. "Caretakers" atuam em todas as atividades dentro da porteira, nas pulverizações, na colheita, no gerenciamento, no controle integrado de pragas, e na compra e venda de insumos e frutas. Acabam sendo estruturas muito importantes para os pequenos produtores “absentee”, porque conseguem propiciar ganhos de escala que não eram atingidos quando tratados separadamente, sem a firma de gerenciamento.

\subsubsection{Firmas de investimentos e gerenciamento}

As firmas de investimento e gerenciamento são negócios de gerenciamento que podem ter ou não terras e/ou maquinário e não utilizam seu próprio capital. Propiciam aos seus clientes informações sobre o comércio da produção, a terra, os insumos e, também, consultoria sobre seguros e crédito. Têm como filosofia: "Propiciar o máximo de informações que puderem para auxiliar na tomada de decisões de seus clientes". Essas empresas, normalmente, possuem apenas escritórios espalhados pelas principais regiões agrícolas dos EUA que centralizam informações sobre compradores e vendedores de terras, empresas terceirizadoras (“caretakers"), fundos de investimentos, e seguros, formando, assim, um grande banco de dados que pode ser utilizado para satisfazer as necessidades dos seus clientes.

No gerenciamento da produção de suas áreas, elas contratam as firmas prestadoras de serviços ("caretakers") para gerenciar sua produção. Podem apenas propiciar informações e/ou formar uma área própria com diversos associados (uma sociedade) e nesta realizar todo o processo administrativo, sempre com o auxílio dos “caretakers". Seus ganhos são provenientes de uma taxa cobrada sobre os custos de produção (10-15\%) e/ou também de comissões de compra ou venda (2-10\%). 


\subsubsection{Sociedades}

As sociedades são as ligações entre proprietários/especialistas e investidores que estarão focados e juntos no negócio de produção de laranja. É um negócio de investimento e gerenciamento, podem ter ou não maquinário. A sociedade tem uma área de atuação ampla e age conforme o tipo de serviço necessário, conjuntamente e/ou apoiadas por empresas prestadoras de serviços. As sociedades são, geralmente de longo prazo, variando de 25 a 35 anos. Grande parte se estabelece em sociedades limitadas, devido as grandes vantagens legais que esses serviços proporcionam, principalmente a exclusão dos bens particulares dos acionistas para cobrir eventuais problemas financeiros da sociedade.

Existem também as sociedades gerais, que se diferem das limitadas em alguns aspectos, sendo o principal a inclusão dos bens particulares de acionistas para cobrir problemas financeiros que a sociedade possa vir a ter. Todas as decisões são tomadas por votação de cada produtor que compõe o conselho da sociedade.

\subsubsection{Cooperativas}

A cooperativa é um tipo de associação de produtores que trabalham unidos para aumentar suas escalas e conseguir maior poder de negociação com todos os elos da cadeia produtiva, além de conseguirem algumas vantagens legais. Normalmente, os produtores elegem 12 pessoas para gerenciar o negócio, e essas pessoas são as responsáveis pelo correto funcionamento da cooperativa, compondo o Conselho. $\mathrm{O}$ grupo é formado por executivos e por alguns produtores escolhidos pelos demais para representá-los no Conselho.

Os integrantes das cooperativas são, habitualmente, pequenos produtores com áreas menores que 40 ha, podendo ser os "growers", "absentee" e/ou as 
sociedades. A cooperativa não possui terras, mas pode ou não ter o maquinário necessário para os serviços nas propriedades de seus cooperados. No caso de não possuir as máquinas, a cooperativa pode contratar uma empresa terceirizadora de serviços para realizar essas operações. Gerenciam toda a produção, desde a simples aplicação de herbicidas e fertilizantes, passando por pulverizações, pela colheita, pelo embalamento de frutas, planejamento, gerenciamento e chegando à comercialização da produção.

Como cooperativas, algumas compartilham lucros e perdas entre todos os cooperados, permitindo um relativo ganho médio para todos os integrantes. Muitas vezes as cooperativas só remuneram seus cooperados no final de cada safra, criando problemas de fluxo de caixa para seus cooperados, haja vista o dispêndio semanal ou mensal para a realização das operações de tratos culturais nos pomares. As cooperativas brasileiras não possuem várias características quando comparadas com as norte-americanas, e a maioria apresenta outro foco de negócio, mas este aspecto será mais bem detalhado na seção sobre as formas de organização existentes no Estado de São Paulo.

Na Figura 5, as seis formas de organização já mencionadas contribuem-se de diferentes formas em relação à propriedade de terra no gerenciamento da produção; está ilustrado o esquema das relações existentes entre os agentes da cadeia produtora de laranja da Flórida, evidenciando-se as relações entre os agentes econômicos. Assim, observa-se que os agentes podem relacionar-se entre si, dependendo da necessidade e do tipo de negócio em que cada um esteja envolvido; assim, as relações estabelecidas entre os agentes envolvidos nesse elo da cadeia produtiva (relações complexas) e as transações contratuais específicas podem ser analisadas mais efetivamente. 


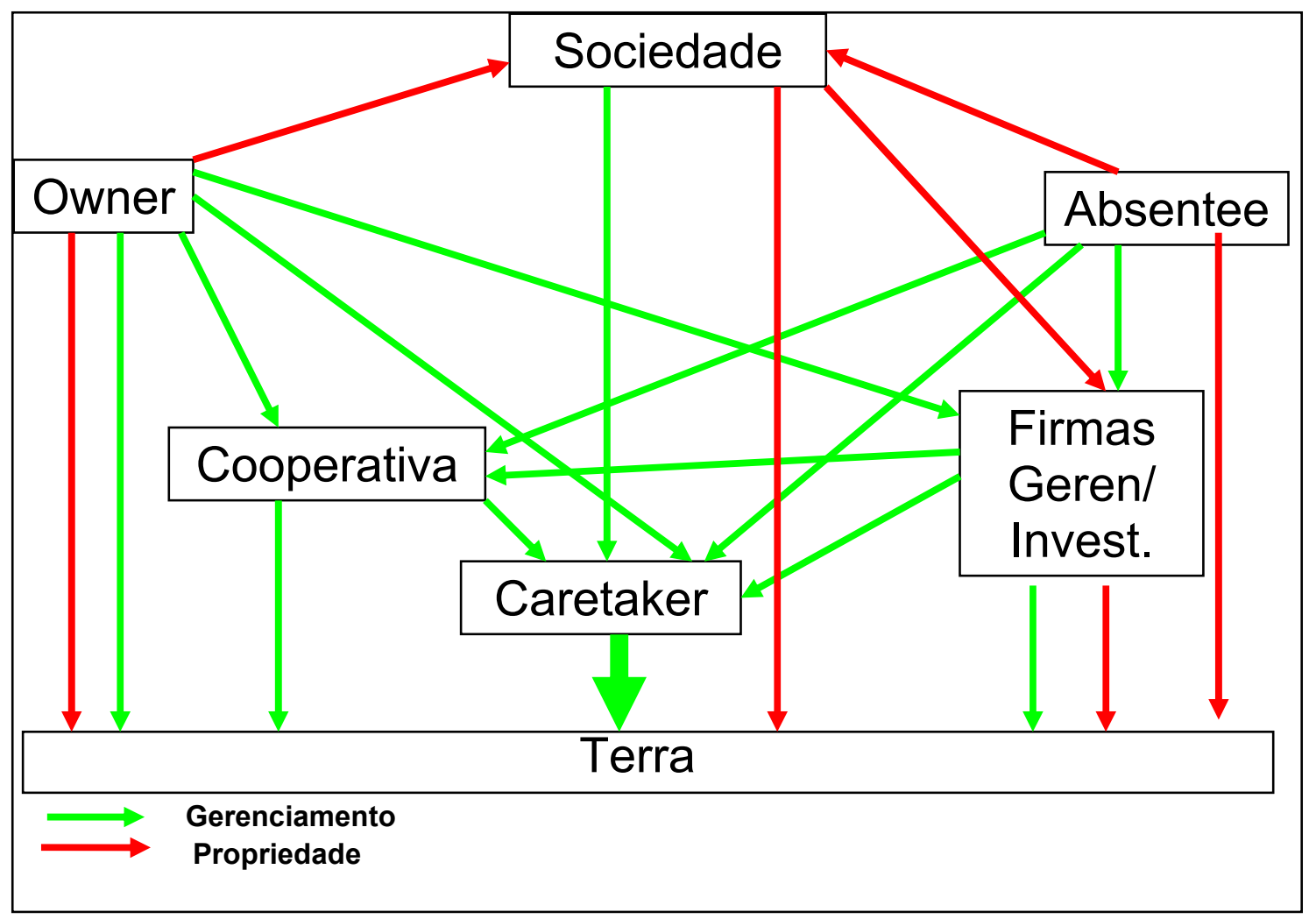

Figura 5 - Relações estabelecidas entre os tipos de negócios na citricultura da Flórida. Fonte: Dragone et al. (2002) e dados da pesquisa.

$\mathrm{Na}$ Figura 5, estão demonstradas, também, as organizações existentes na produção de laranja dos EUA. Tais ligações estão intimamente relacionadas com a disponibilidade de agentes que oferecem seus serviços terceirizados ao setor, como por exemplo, os “caretakers", sendo componentes essenciais na ligação entre os produtores/investidores e a produção propriamente dita. Na inexistência desses agentes, como no caso paulista, fica evidente a dificuldade de se implementar uma atividade como essa, terceirizando serviços na produção.

Observa-se ainda, na Figura 5, que uma Firma de Gerenciamento e Investimento pode ter a propriedade da terra ou não, pode prover todo o gerenciamento da terra ou pode contratar uma firma terceirizadora de serviços (“caretakers"); pode, 
ainda, fazer parte de uma cooperativa ou sociedade e estas juntas, proporcionarem os serviços ou contratarem serviços de terceiros.

$\mathrm{Na}$ Tabela 4, tem-se uma visão de propriedade e gerenciamento dos agentes envolvidos na atividade de produção de laranja na Flórida. Constam, também, os modelo de administração utilizados na citricultura norte-americana e suas relações de propriedade de terra, gerenciamento técnico/marketing, propriedade de equipamentos e mesmo de capital, distintos e característicos para cada sistema, salientando-se as relações contratuais entre as empresas e qual seria o melhor caminho para a estruturação negocial para cada tipo de atividade.

\begin{tabular}{|l|c|c|c|c|}
\hline & $\begin{array}{c}\text { Propriedade } \\
\text { da Terra }\end{array}$ & $\begin{array}{c}\text { Gerenciamento } \\
\text { Técnico/Marketing }\end{array}$ & $\begin{array}{c}\text { Propriedade das } \\
\text { Máquinas }\end{array}$ & $\begin{array}{c}\text { Propriedade } \\
\text { do Capital }\end{array}$ \\
\hline Growers & $\mathbf{X}$ & $\mathbf{X}$ & $\mathrm{X}$ & $\mathrm{X}$ \\
\hline Absentees & $\mathrm{X}$ & & & $\mathrm{X}$ \\
\hline Caretakers & & $\mathrm{X}$ & $\mathrm{X}$ & \\
\hline Invest. \& Geren. & $\mathrm{X}$ & $\mathrm{X}$ & $\mathrm{X}$ & \\
\hline Cooperativas & & $\mathrm{X}$ & $\mathrm{X}$ & \\
\hline Sociedades & $\mathrm{X}$ & $\mathrm{X}$ & $\mathrm{X}$ & $\mathrm{X}$ \\
\hline
\end{tabular}

Quadro 4 - Produção de laranja na Flórida: uma visão de propriedade e gerenciamento. Fonte: Dragone et al. (2002) e dados da pesquisa.

Nota: O sinal X significa relacionamento do agente econômico da organização com a propriedade e/ou gerenciamento no negócio da citricultura.

${ }^{1}$ Firmas de Gerenciamento e Investimento

\subsubsection{Formas de organizações encontradas no Estado de São Paulo (Brasil)}

No Estado de São Paulo, a organização da citricultura apresenta diferenças quando comparada com a do Estado da Flórida. A seguir, são discutidos e caracterizados os principais tipos de agentes econômicos e de negócios existentes no 
Estado, obtidos, principalmente por meio de entrevistas e pesquisas, caracterizadas em maior profundidade no capítulo de revisão de literatura, juntamente com os trabalhos sobre os aspectos relacionados com as formas de organização da produção.

\subsubsection{Produtor}

O produtor é o grande participante da indústria cítrica paulista. Os produtores detêm todo o tipo de equipamento necessário para a realização das operações em sua propriedade.Geralmente, são produtores tradicionais que estão, na terceira geração da família. As propriedades vão desde poucos hectares no fundo de uma área até as que ultrapassam os 10.000 ha.

Há evidências, segundo Amaro et al. (2001), de que aproximadamente 90\% da produção paulista seja obtida por proprietários e assalariados da atividade (residentes versus donos) e não por investidores.

Segundo Amaro et al. (2001), na safra 1995/96, 74\% das propriedades tinham menos de 50 ha, 19\% possuíam entre 50ha e 200 ha, e apenas $7 \%$ tinham mais de 200 ha. Em face da variabilidade do "stand" de plantas nos talhões e pomares de laranja e com o avanço do plantio adensado, outras classificações foram estabelecidas, optandose, atualmente, pelo número de plantas (em formação ou em produção) existentes e não a quantidade existente por hectare. Uma recente pesquisa (FUNDECITRUS, 2003) estimou a existência de 28.000 propriedades cítricas no estado e triângulo mineiro; $93 \%$ delas com 200 a 20 mil plantas, 5\% com 20 mil a 100 mil plantas, e apenas $1 \%$ com mais de 100 mil plantas. Por um lado, fica evidenciada a pulverização dos pequenos produtores que podem não ter estrutura/escala suficiente para manter seu negócio estável; por outro, não existe a possibilidade de terceirização dos serviços nessas propriedades de pequeno porte, devido à sua desorganização de seu sistema de 
produção, que não formam associações e à inexistência de firmas prestadoras desse tipo de serviço.

Uma parte dos produtores do estado de São Paulo foi obrigada a deixar o setor, devido à crise de preço ocorrida no final dos anos 90, quando o número de produtores caiu de 29 mil e para $17 \mathrm{mil}^{8}$ (FUNDECITRUS, 2001), gerando uma transferência significativa das áreas de laranja para as de cana-de-açúcar. O contrário ocorreu nos anos 80 e início dos 90, quando se intensificou a busca por áreas para a citricultura, por parte de profissionais liberais, que a enxergavam como um negócio atrativo, mas investiam no setor sem o aprofundamento e o profissionalismo necessários para conduzir o negócio.

Neste início de década, os produtores que permanecem na citricultura são mais profissionais, técnicos e ativos comerciantes visando à sustentação do negócio de forma mais competitiva.

\subsubsection{Cooperativas}

As Cooperativas são formadas, na sua maioria, por produtores que se unem para conseguir ganhos de escala na atividade. No Brasil, historicamente os sucessos de cooperativas na citricultura são escassos, existindo atualmente apenas alguns exemplos em atividade, como a Coopercitrus e a Credicitrus.

A Coopercitrus possui uma equipe técnica de 1.300 profissionais oferecendo apoio intensivo aos seus 13.000 cooperados, fortalecendo-se como uma das maiores cooperativas do Brasil na atualidade, tendo faturado, em 2002, R $\$ 522$ milhões. A maior parte (50\%) de seus cooperados possui área plantada inferior a 30 ha. Com mais

\footnotetext{
${ }^{8}$ Alguns estudos demonstram que esse número pode chegar a 18 mil se todos os produtores de laranja forem contados.
} 
de 100 ha de área são apenas 3\% do total, ressaltando-se a estrutura de cooperativa específica para pequenos produtores e ainda pertencer a uma instituição desse porte. A Coopercitrus $^{9}$ atende por meio de seus produtores/cooperados, atualmente, 1.520 milhão de hectares de cana-de-açúcar, 534,3 mil de citros, 285 mil de soja, compreendendo respectivamente $40 \%, 75 \%$ e $50 \%$ das áreas cultivadas com essas culturas comercias no estado de São Paulo. Sua principal função é a venda de insumos para seus cooperados, recebendo e vendendo $40 \%$ a $60 \%$ dos insumos comercializados no Estado. Os produtores compram fertilizantes, defensivos e máquinas da cooperativa a preço de mercado, mas com uma vantagem: no final de cada ano há a divisão das sobras (excedente de capital acumulado) entre os cooperados, ocorrendo assim, uma diferença nos gastos dos seus associados. Possui também supermercados, postos de gasolina, conta com toda um infraestrutura logística de apoio para armazenagem de grãos, oferece crédito e assistência técnica. No crédito, a cooperativa funciona como um intermediário entre os agentes financeiros públicos e privados e os produtores rurais. Porém, uma cooperativa desse porte não conta com uma estrutura de serviços para seus cooperados, o que será discutido na próxima seção.

Já a Credicitrus é uma cooperativa independente, mas que possui uma relação próxima com a Coopercitrus. É a maior cooperativa de crédito rural do país atualmente. Pratica todas as operações ativas, passivas e acessórias típicas de nossa modalidade social. Conta, atualmente, com 16 Postos de Atendimento Cooperativo, 74 funcionários, 18 estagiários e 5.600 associados. Seu ativo circulante em 2002 foi de $\mathrm{R} \$ 228$ milhões, quase $\mathrm{R} \$ 75$ milhões superiores a 2001, com um mercado em franco crescimento e potencial no país.

As vantagens de se trabalhar com o cooperativismo são, entre outras, a geração de economias de escala, redução dos custos de informação e comunicação, e otimização dos custos de produção e transação.

\footnotetext{
${ }^{9}$ Dados sobre a Coopercitrus coletados no prospecto institucional da cooperativa do ano de 2003.
} 
Fazendo um comparativo com as cooperativas norte-americanas pode-se concluir que as brasileiras têm como principal foco de negócio a venda de insumos aos seus cooperados, já, as norte-americanas possuem toda uma estrutura para fornecimento de serviços relacionados à produção a seus membros. Embora possuam o mesmo conceito as cooperativas brasileira e norte-americana apresentam funções e características muito distintas entre si.

\subsubsection{Empresas}

As Empresas são exemplos de sucesso na citricultura paulista e nacional, porque as principais indústrias processadoras de laranja da atualidade provêm de famílias tradicionais de produtores. São as empresas que dominam o cenário internacional de Suco de Laranja Concentrado e Congelado (SLCC), mostrando eficiência, competitividade e profissionalismo na gestão do negócio cítrico nacional e internacional. Sendo assim, dessa categoria fazem parte grandes produtores e/ou indústrias processadoras com seus pomares.

Existem, além das indústrias processadoras, outras empresas produtoras de laranja que têm obtido resultados atrativos e ainda mostrado a excelência do setor nessa área. Tais empresas não possuem indústrias processadoras de laranja, isto é, produção de SLCC, mas estão inseridas no elo da produção de laranja para abastecimento das indústrias. São geridas por empresários ou executivos, que sempre buscam as melhores alternativas de produção com eficiência e eficácia. Possuem contratos de venda de matéria-prima para as indústrias em valores superiores aos de mercado porque conseguem ganhos de escala e minimizam os custos de negociação para as empresas compradoras; isto é, a negociação é facilitada e menos dispendiosa quando se trata de 500 mil caixas de laranja de $40,8 \mathrm{Kg}$, em vez de 5 mil caixas de $40,8 \mathrm{Kg}$, gerando assim, economia nos custos de transação, aspecto que será abordado com mais profundidade no arcabouço teórico deste estudo. 
Normalmente, essas empresas são de grande porte, com áreas maiores de 500 ha, as quais possuem a estrutura necessária para a realização de todas as atividades envolvidas na produção de laranja.

\subsubsection{4 "Pool"}

"Pool" são associações de produtores que se unem para adquirir maior poder de negociação no mercado. Na citricultura paulista não são comumente encontradas, existindo apenas alguns poucos exemplos de sucesso, como a exCOMCITRUS, atual Condomínio de Produtores em Bebedouro e o CITROSPOOL, em Monte Azul. Existem, também, algumas formas de aluguel de estruturas industriais para o processamento de matéria-prima por parte de alguns produtores. Esses Pools podem ter um sistema de venda de laranja conjunta, inclusive do suco pronto, produzido via aluguel pelas indústrias processadoras. Na produção, trabalham separadamente, como se fossem propriedades distintas e sem relação específica. Então, cada uma possui sua estrutura administrativa e seu corpo técnico, além dos equipamentos necessários para as atividades de pulverização, adubação e outras operações vitais para o andamento do negócio.

Atualmente, mudanças vêm ocorrendo, porque o condomínio de produtores já tem uma equipe técnica com engenheiros agrônomos e técnicos agrícolas que são responsáveis pela assistência técnica de seus associados e, freqüentemente, promovem palestras aos seus membros, mostrando novas tecnologias e processos, para que o grupo sempre esteja à frente no processo tecnológico. Uma das associações desenvolveu um tipo de seguro que é um fundo administrado pela sede do "pool", gerado por meio de contribuições de todos os integrantes com a finalidade de cobrir eventuais problemas de produção que podem ocorrer com os parceiros. 
Pompeu e Neves (1999) relatam que as associações existentes sempre estiveram ligadas prioritariamente às negociações de preços das frutas cítricas, e também à obtenção e disseminação de informações a respeito do mercado internacional e à orientação geral aos associados. Assim, com essa mentalidade, foi criada em 1933 a primeira associação citrícola do Estado de São Paulo. Depois, em 1974, criou-se a Associação Paulista de Citricultores (ASSOCITRUS), formada apenas por produtores de citros, mas que não se manteve ativa até os dias de hoje devido a problemas internos. As filosofias iniciais foram mantidas firmes e constantes sem modificações, fato esse que os autores consideram como um dos fatores de insucesso, porque as associações praticam discussões de preço com as indústrias de forma infrutífera, e também porque servem como um dos primeiros passos para que se consolidem as aspirações políticas de seus componentes. A Associação Brasileira de Exportadores de Citrus (ABECITRUS), criada em 1988, trabalha em outra frente, agregando inicialmente a Cutrale - que saíra da ABRASSUCOS (Associação Brasileira das Indústrias de Sucos Cítricos), e está totalmente focada oferecer informações e realizar marketing para seus associados, visando principalmente à obtenção de maiores mercados para o Suco de Laranja Congelado e Concentrado (SLCC). As associações das indústrias exportadoras se uniram e estabeleceram a ABECITRUS, que passou a ser a única porta-voz das estratégias e decisões das indústrias de suco concentrado no mercado.

\subsubsection{Sociedades}

A Sociedade é um tipo de negócio não muito comum no setor cítrico brasileiro, isto é, comparado ao que ocorre nos Estados Unidos. Diferentemente do que ocorre na citricultura da Flórida, onde esse tipo de empreendimento considera a união entre um especialista/investidor, isto é, uma sociedade trabalho/capital. Em São Paulo, nesse tipo de sociedade ocorre a união entre duas pessoas (investidores) com capital e interesse em investir nessa atividade. Normalmente formam grandes propriedades, superiores a 500 ha para conseguir relativo ganho de escala e bom poder de negociação 
no mercado. Além disso, essa estrutura tem um tamanho suficiente para a instalação de máquinas que realizarão operações de tratos de pomares, entre outras.

Estruturas de larga escala (economias de escala) que apresentam um aporte estrutural de tamanho, número de máquinas, funcionários facilita a incorporação de atividades operacionais na produção cítrica. Assessorias técnicas são implementadas na busca do melhor emprego das técnicas de produção mais modernas. Tudo isso faz com que a Sociedade seja equivalente à categoria empresa.

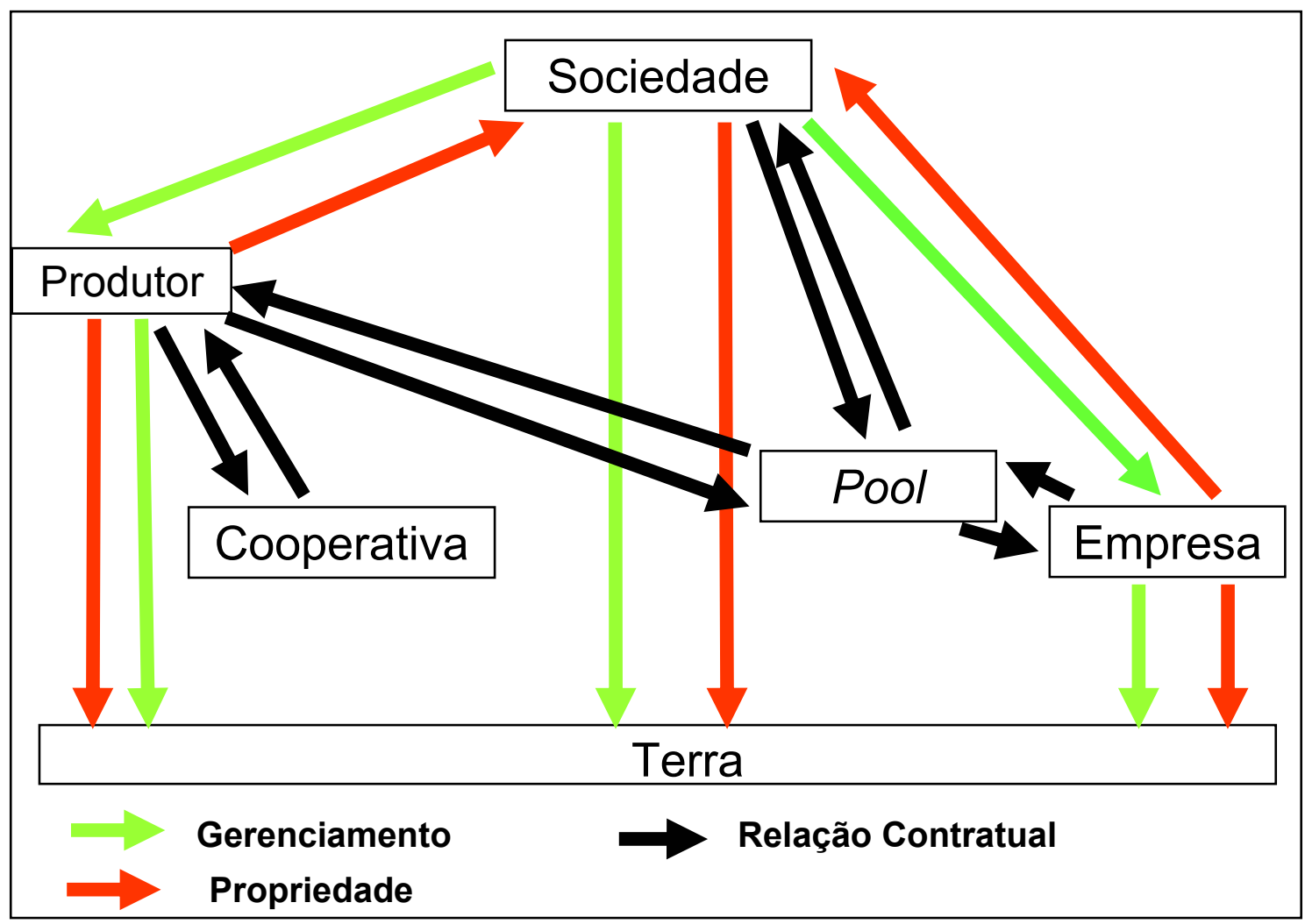

Figura 6 - Relações existentes entre os tipos de negócios na citricultura de São Paulo. Fonte: Dados de pesquisa.

Na Figura 6, observam-se as relações existentes entre os agentes da produção na citricultura de São Paulo muito mais rígida e menos flexível que as do estado da Flórida, pois não contam com os Caretakers, Absentee e Firmas de 
Gerenciamento e Investimentos. Nota-se que os produtores gerenciam e têm propriedade da terra, mas podem estabelecer relações com Pools, Cooperativas e Sociedades. Porém, somente a empresa, o produtor individual e as sociedades possuem propriedades e fazem o gerenciamento da terra. Atualmente as relações contratuais entre os agentes estão mais ligadas à obtenção de poder de barganha e de vantagens na compra de insumos e, em alguns casos, na venda de produtos finais.

As relações contratuais funcionam como uma associação entre os agentes, em que cada indivíduo tenta se beneficiar da estrutura na qual está integrado, visando o máximo de aproveitamento. Assim, as relações contratuais, esquematizadas na Figura 6, ilustram apenas a existência de uma relação entre esses agentes, mas não quer dizer que sejam regidas por contratos.

\begin{tabular}{|l|c|c|c|c|}
\hline & $\begin{array}{c}\text { Propriedade } \\
\text { da Terra }\end{array}$ & $\begin{array}{c}\text { Gerenciamento } \\
\text { Técnico/Marketing }\end{array}$ & $\begin{array}{c}\text { Propriedade das } \\
\text { Máquinas }\end{array}$ & $\begin{array}{c}\text { Propriedade } \\
\text { do Capital }\end{array}$ \\
\hline Produtores & $\mathbf{X}$ & $\mathbf{X}$ & $\mathbf{X}$ & $\mathbf{X}$ \\
\hline Empresas & $\mathbf{X}$ & $\mathbf{X}$ & $\mathbf{X}$ & $\mathrm{X}$ \\
\hline Pools & & $\mathbf{X}$ & & \\
\hline Cooperativas & & $\mathbf{X}^{1}$ & & \\
\hline Sociedades & $\mathrm{X}$ & $\mathbf{X}$ & $\mathbf{X}$ & $\mathbf{X}$ \\
\hline
\end{tabular}

Quadro 5 - Produção de laranja no estado de São Paulo: uma visão de propriedade e gerenciamento.

Fonte: Dados de pesquisa.

Nota: O sinal X significa relacionamento do agente econômico da organização com a propriedade e/ou gerenciamento no negócio da citricultura.

${ }^{1}$ Gerenciamento, principalmente, na venda de insumos agrícolas

No Quadro 5, ilustra-se a produção de laranja no estado de São Paulo visando facilitar o entendimento das relações existentes entre os agentes dessa cadeia de produção. Vê-se que o Pool e as cooperativas possuem somente uma estrutura de associação, promovendo palestras e informações para seus integrantes e somente em 
alguns casos, a comercialização de produtos para seus associados. Na maioria dos casos, essas associações têm outros focos de negócios não relacionados com a produção de laranja de seus associados, isto é, elas propiciam apenas a estrutura de serviços e máquinas, como ocorre nas cooperativas, que têm como principal negócio à venda de insumos para a sociedade em geral, a preços maiores que o de mercado.

Portanto, observam-se similaridades e diferenças entre os dois sistemas existentes nas duas maiores regiões produtoras de laranja do mundo. A seguir, estão destacadas as principais diferenças e similaridades e questiona-se os problemas e as causas prováveis do sucesso ou não dos diferentes modelos de investimento e gerenciamento da produção de laranja no estado São Paulo e no estado da Flórida.

\subsubsection{Comparações entre os dois modelos de negócio}

Ao se comparar os tipos de negócios existentes na citricultura da Flórida e de São Paulo, fica evidente que ambas as regiões têm a citricultura como uma fonte importante na arrecadação de divisas, obtendo valores superiores a US\$ 1 bilhão anuais. Já em número de produtores, São Paulo aparece em vantagem com 17.000, e a Flórida com menos de 12.000. Segundo o FUNDECITRUS, essa diferença numérica já foi maior, sendo aproximadamente 29.000 produtores em São Paulo, no início da década de 90. Com as crises enfrentadas pelo setor no final do milênio, principalmente devido aos preços baixos, não remuneradores nos anos de 1999 e 2000, ocorreu uma substituição de áreas com laranja para cana-de-açúcar.

As estruturas de negócio são bem distintas, mas cada uma apresenta suas vantagens, quando comparadas entre si. Na Flórida existem: Growers, Absentee, Sociedades, Firmas de Gerenciamento e Investimentos, Caretakers, Cooperativas. Já, em São Paulo, predominam: Produtores, Empresas, Cooperativas, Pools e Sociedades. É importante salientar que o ambiente institucional e a forma de governança, utilizadas em 
cada estado produtor, são possivelmente aqueles que melhor se encaixam em cada região. As taxas de retorno anual em outras atividades, sem risco, isto é, as taxas de desconto do governo nos dois países são diferentes. No Brasil, são superiores a 15\%, chegando a 22,5\% ao ano (Taxa SELIC - Agosto/2003) e nos EUA chegam a ser inferiores a $2 \%$, sendo $1,75 \%$ ao ano. Isto mostra que um projeto de investimento pode ser aceito numa região e recusado em outra, dependendo da taxa de retorno do projeto. Fazendo com que na existência de altas taxas de retornos de investimentos alternativos dificulte a entrada de investidores na atividade, isto é, investindo em títulos do governo (praticamente sem risco) o investidor terá retornos superiores à agricultura (citricultura), porém, com um risco muito mais elevado. Ambas possuem um sistema financeiro sólido e bem estruturado.

Uma das principais diferenças entre os dois países é a existência de barreiras protecionistas à entrada do suco de laranja no mercado norte-americano. No Brasil, a citricultura trabalha de forma globalizada, com eficiência e competitividade direcionados para o mercado mundial. Já os EUA têm um mercado fechado e protegido, tarifado em US\$ 418 por tonelada de SLCC para o suco brasileiro focado no mercado interno. Essa é apenas uma das tarifas do SLCC, pois nos EUA, tem-se ainda a tarifa de US\$ 40 por tonelada de SLCC adicionais à anterior, que vai para a promoção do SLCC americano, que é a taxa de equalização. Quando se quantificam essas tarifas com os preços do SLCC no mercado internacional, que variou de US\$650 - US\$ 1.300 por tonelada, ao longo dos últimos 10 anos (1993-2002), representando aproximadamente $30 \%$ a $60 \%$ dos preços praticados no mercado internacional, mostrando o peso dessa barreira para as indústrias exportadoras. Após anos de preços baixos no mercado internacional, a crise no setor se espalha nas regiões paulista e mineira (Triângulo Mineiro) produtoras de laranja e de suco concentrado, por serem o elo mais fraco na cadeia produtiva e sofrem o impacto de crises mais intensamente do que os outros segmentos da cadeia no mercado. Num mercado bem protegido e de baixo risco como o da Flórida, a entrada de investidores e agentes econômicos não- agrícolas são freqüentes na cadeia cítrica. 
Registra-se ainda o forte protecionismo imposto ao setor cítrico pelo governo americano nos Acordos Comerciais. Neves (1994, p.87) cita que "nas negociações envolvendo produtos agrícolas, México e EUA acordaram a eliminação imediata de todas as barreiras não-tarifárias ao comércio agrícola que serão transformadas em tarifas especiais com quotas especificadas. Para os produtos que não são considerados sensíveis, a eliminação das barreiras tarifárias ao comércio bilateral é imediata. Os produtos sobre os quais ainda incidirem tarifas terão alíquotas reduzidas a zero no prazo máximo de 10 anos. As exceções a essa regra ficam restritas ao milho e feijão americanos e ao suco de laranja e açúcar produzidos no México, que terão tarifas eliminadas pelos respectivos importadores no prazo de 15 anos, após a implementação do acordo. Adiante, o acordo diz que durante os primeiros dez anos de vigência do NAFTA, é facultado às partes signatárias fazer uso do mecanismo de salvaguarda, sempre que as importações de produtos considerados sensíveis atingirem os níveis críticos estabelecidos no Acordo. Em tais circunstâncias, o país importador pode aplicar a tarifa em vigor, na época em que o acordo foi implementado ou aplicar a tarifa definida pela cláusula da nação mais favorecida (prevalece, neste caso, a que for menor)". Neste acordo, é evidente o forte protecionismo imposto pelo governo americano a citricultura da Flórida.

$\mathrm{Na}$ parte técnica, existem algumas diferenças entre as variedades cultivadas que não foram citadas anteriormente, mas que são importantes no sistema de produção de cada país. No Brasil, predomina a laranja Pêra, diferenciando-se da encontrada nos EUA que é dividida proporcionalmente entre outras, como por exemplo, a Navel, Hamlin e a Valência. Os programas de pulverizações têm períodos muito bem definidos e específicos na Flórida, para cada tipo de praga e/ou doença. Em São Paulo, as pulverizações não são bem definidas, dependendo muito das condições climáticas e infestações existentes, e pelo fato de a colheita se espalhar em mais meses do ano. No Brasil, praticamente são 9 meses ou mais, devido ao número maior de variedades plantadas e colheitas temporãs, diferentemente do que ocorre na Flórida, cuja colheita se 
resume a 6 meses, em média (Viegas \& Guimarães, 1991). No Brasil, podem ocorrer ainda safras temporãs dependendo das condições pluviométricas e climáticas com produções irregulares, o que inviabiliza programas de pulverizações regulares.

As duas regiões possuem algumas similaridades e diferenças em diversos aspectos. Nesta seção do estudo listam-se alguns aspectos importantes de cada um dos modelos, resumidos no Quadro 6.

O negócio cítrico na Flórida é mais bem organizado que o brasileiro com menores riscos e incertezas no gerenciamento da produção e mais atratividade para a aplicação de fundos de investimentos. Por exemplo, a confiabilidade no inventário cítrico realizado a cada dois anos, dividindo as plantas em grupos de idade e estes divididos em grupos de variedades, tem permitido bons ajustamentos em estudos previsionais que levam em conta a produtividade média histórica, o número de árvores, o efeito da idade da árvore na produtividade e o efeito da variedade da fruta na produtividade. Essas informações são consideradas úteis para os analistas de fundos de investimentos e empresas de gerenciamento de produção (Morris \& Morris, 1995). Segundo os autores, as projeções podem ser prejudicadas pela demanda de importações americanas de suco concentrado e pelas estatísticas brasileiras, que não dispõem de mecanismos de inventário tão apurados como os existentes na Flórida. 


\begin{tabular}{|l|c|c|}
\hline & São Paulo & Flórida \\
\hline Número de Produtores & 17.000 & 12.000 \\
\hline Estruturas de Negócios & $\begin{array}{c}\text { Produtores, Empresas, } \\
\text { Cooperativas, Sociedades, } \\
\text { Pools }\end{array}$ & $\begin{array}{c}\text { Growers, Absentee, Sociedades, Firmas } \\
\text { de Investimento e Gerenciamento, } \\
\text { Caretakers, Cooperativas }\end{array}$ \\
\hline Valor - Divisas & $>$ US\$ 1 bilhão & BS\$ 1 bilhão \\
\hline atividades (sem risco/taxa de & Alta (>15\%) & Baixa (<2\%) \\
desconto do governo) & & Bem organizado \\
\hline Estrutura Financeira & & \\
\hline Barreiras Tarifárias & Bem organizado & US\$ 418/t + US\$ 40/t (mkt) \\
\hline $\begin{array}{l}\text { Programa de Pulverizações contra } \\
\text { Pragas }\end{array}$ & Pulverizações não são & Pulverizações são bem definidas \\
\hline Variedades Utilizadas & bem definidas & Hexistente (exportador) \\
\hline
\end{tabular}

Quadro 6 - Flórida x São Paulo: principais diferenças e similaridades.

Fonte: Dragone et al. (2002) e dados de pesquisa elaborados pelo autor.

${ }^{1}$ Apresenta sistema financeiro estruturado e organizado suficientemente para apoiar as formas de organização como tipo de investimento.

${ }^{2}$ SLCC - Suco de Laranja Concentrado e Congelado.

${ }^{3}$ MKT - Tarifa adicional do SLCC utilizada para a promoção do suco americano.

Garcia (1993) citado por Neves (1996, p.78) destaca que o nível de organização de mercado que é mais bem estruturado nos EUA, não somente em função do desenvolvimento da quase integração, mas também "pela criação de entidades conjuntas de citricultores e indústrias, caso da Florida Citrus Commission, que trata de proteger e promover a produção cítrica e a Florida Citrus Exchange, fórum para realizações de negócios, além do importante papel da Universidade e do Estado (USDA) nas pesquisas de desenvolvimento da laranja na Flórida e no fornecimento, aos produtores e indústria, de informações, estudos e estatísticas”. 
O protecionismo à citricultura da Flórida ao longo do tempo e sua atratividade para investimentos tornou o negócio cítrico atraente para diferentes agentes econômicos. Ward e Kilmer, citados por Neves (1996, p.77) verificaram que no período de 20 anos (1959/60 a 1978/79) o maior processador manteve uma participação no mercado ao redor de $12 \%$ e que as 4 maiores empresas, de 35 a 40\%. Concluíram que “a) a indústria de processamento de citros na Flórida não é altamente concentrada; b) no período estudado, os valores de cada índice mostravam um alto grau de estabilidade quando medido pelo coeficiente de variação. Esse fator de estabilidade indicava que houve pouca mudança no poder de mercado e que a entrada e saída de firmas (medida pelo número de firmas no mercado) teve pequena influência nas mudanças no nível de concentração industrial. Além disso, o nível de organização do mercado é mais eficiente do que em São Paulo, onde se assistiu, ao longo dos primeiros anos desta década, relações conflituosas entre citricultores e a indústria”.

Neves (1996, p.78) ressalta também que "a alta concentração do complexo cítrico paulista no plano industrial propiciou, ao longo das décadas passadas, maior capacidade de reter o excedente gerado e um melhor planejamento de suas ações futuras. O valor agregado foi considerável, de tal forma que a estrutura industrial de sucos cítricos no estado de São Paulo é, talvez, a mais moderna e ágil no setor e com a melhor logística internacional”. Resumindo, o Brasil possui um modelo extremamente competitivo e eficiente de produção de suco e laranja, fato comprovado pela liderança mundial em produção e processamento de laranja.

Naturalmente, tais condições especiais de organização de mercado e de políticas de suporte à citricultura da Flórida criam mecanismos confiáveis e de riscos atrativos aos fundos de investimento e gerenciamento da produção. A terceirização de serviços técnicos na citricultura é uma atividade muito comum para os citricultores americanos, enquanto que para os brasileiros, ainda é problemática, porque toda a citricultura nacional está estruturada para um tipo de negócio no qual a terceirização de serviços inexiste. Desta forma, o sistema é ineficiente em que, por exemplo, 
propriedades de 20 ha que contam com trator, pulverizador e adubadeira estão distantes de operarem com economias de escala. Certamente, uma propriedade assim está com maquinário subutilizado, evidenciando-se a desorganização do setor produtivo em São Paulo e Minas Gerais.

Outro aspecto interessante na indústria cítrica mundial é que as variedades não são apropriadas à industrialização e ao consumo in natura simultaneamente, isto é, existem variedades específicas para a industrialização que produzem uma maior quantidade de suco e variedades para o consumo in natura que possuem casca mais fina, não possuem sementes e têm sabor realçado. Tentar explorar mercados onde as frutas não são especializadas gera confusões e até mesmo problemas, como ocorre na venda sem orientação da variedade de laranja Pêra para consumo in natura e não para suco, nos supermercados. No Brasil, mais especificamente em São Paulo, isso ocorre porque a indústria é e foi a criadora de demanda de laranja, então, toda a produção de laranja está totalmente voltada à indústria, fato que gera conflitos nos anos em que há recessão e excesso de produção.

Essas descrições evidenciam que existem diferenças e similaridades entre os tipos de negócios encontrados em São Paulo e na Flórida determinando-se tipo e região algumas vantagens e desvantagens. Um aprofundamento analítico no entendimento destas diferenças e similaridades é indispensável para a compreensão das alterações e decisões de diferentes agentes econômicos nas negociações da citricultura.

A próxima seção aborda o segundo objetivo deste estudo, que é o de determinar a implementação da terceirização na citricultura e investimentos externos na citricultura, trazendo os principais problemas levantados nas entrevistas com agentes do setor, bem como as relações entre a teoria e a prática aplicadas no direcionamento de caracterização de suas potencialidades, limitações ou possibilidades. 


\subsection{Decisões de terceirização na produção e investimentos externos na citricultura}

Nesta seção é relatado o segundo objetivo desse estudo, as decisões de terceirização na produção e investimentos externos na citricultura, pesquisando suas potencialidades, possibilidades e limitações. A seguir são detalhados os problemas citados pelos agentes econômicos do setor nas entrevistas de campo, que podem estar influenciando positiva ou negativamente os ganhos de competitividade da citricultura. Para melhor compreensão dos problemas existentes a seção é dividida em quatro tópicos principais: culturais, econômicos, mão-de-obra na colheita e técnicos.

\subsubsection{Culturais (Ambiente Institucional)}

As normas de conduta das pessoas relacionadas as atividades sociais estão entre os elementos mais importantes da cultura organizacional. Para Schein, citado por Maximiliano (2000, p.256), “a cultura é a experiência que o grupo adquire à medida que resolve seus problemas de adaptação externa e integração interna, e que funciona suficientemente bem para ser considerada válida. Portanto, essa experiência pode ser ensinada aos novos integrantes como forma correta de perceber, pensar e sentir-se em relação a esses problemas".

Pode-se retirar desse conceito que cultura organizacional é mais complexa do que simplesmente pensar em se apoiar em normas de conduta. Para Hannagam, citado por Maximiliano (2000, p.259), "uma cultura nacional é formada por valores e atitudes, religião, linguagem, educação e contexto político-legal, fatores que são influenciados pela história e pelas crenças das pessoas, que variam de uma região para outra".

Pois bem, a cultura organizacional e institucional no meio rural é a mais resistente às mudanças devido principalmente ao ambiente campesino, ao grau de 
escolaridade dos agricultores e ao quadro de referência mais estreito e localizado no tempo e espaço geográfico. Desconfiança, aversão a risco e inovações, padrões de comunicação deficientes dão consistência à identificação da cultura rural, principalmente dos proprietários e administradores em São Paulo.

As respostas obtidas nas entrevistas mostram que o problema cultural em São Paulo é o mais sério e se arrasta desde o início das colonizações. Os produtores têm, na sua maioria, uma cultura de resistência; por exemplo, quando são sugeridas mudanças de estrutura, tecnologia ou técnicas a serem empregadas no campo, os produtores dificilmente são convencidos a adotarem uma nova tecnologia. Isso ocorre porque a cultura dos produtores, principalmente os tradicionais, acaba impondo certa resistência às alterações constantes e variadas que surgem no manejo de técnicas de plantio e na manutenção de pomares, recomendados pelos institutos de pesquisas e de assistência técnica. A desconfiança vem da aversão ao risco, condicionada principalmente pelo temor ao novo e a preocupação com custos adicionais que possam ter.

Segundo Amaro et al. (2000) a escolaridade dos produtores cítricos no Estado de São Paulo é de 6 anos de estudo, em média, enquanto que a dos administradores das fazendas é de 4 anos. Novamente, observa-se que conscientizar um produtor de algo a ser feito é tarefa difícil, pois ele já carrega consigo seus valores, suas crenças e certa resistência às mudanças tecnológicas. As respostas obtidas nas entrevistas mostraram que os produtores tendem, de início, a desconfiar das novas idéias, depois a resistência já é menor e leva certo tempo para sua efetiva implementação.

Para Baptistella et al. (1994), nesse sentido, a dificuldade na adoção de novas tecnologias e instrumentos gerenciais estaria associada à estrutura fundiária da citricultura onde os miniprodutores ( 3,0 a 20,0 ha) correspondiam a $35,5 \%$ dos produtores cítricos, os pequenos (20,1 a 100,0 ha) a 48\%; os médios (100,1 a 500 ha) 
cerca de $14 \%$ e os grandes (acima de 500 ha) a apenas 2,4\% dos citricultores, mas detendo cerca de $20,0 \%$ da produção.

Naturalmente essa estrutura fundiária altamente concentrada na mini e pequena produções e o grau de escolaridade dos produtores prevalecente nestas faixas prejudicaram o interesse de outros investidores no mercado e o relacionamento produtorindústria.

Pompeu e Neves (1999) relatam que o principal fator responsável por essa disparidade entre a indústria e o produtor é a grande heterogeneidade do nível educacional dos integrantes das entidades representantes de cada classe, ocasionando grandes assimetrias de opiniões e de interpretações de informações relevantes aos grupos. Os autores ainda descrevem que aproximadamente $30 \%$ dos integrantes das associações de produtores mal sabiam ler e escrever, dificultando o entendimento e aumentando os conflitos internos do grupo.

Quando se trata da adoção de um procedimento novo (tecnológico, comercial ou negocial) verifica-se que sua implementação é um processo muito demorado na agricultura. Como o número de anos de educação é menor em relação ao meio urbano, o conhecimento fica mais limitado e complicado, principalmente num cenário de globalização, onde o mercado está preocupado com os consumidores externos. Assim, há resistência também na união de produtores para o fortalecimento do setor cítrico, principalmente. Nos EUA, os produtores são mais bem organizados, exercendo forte "lobby" no Congresso Americano, o que explica o distorcido protecionismo do mercado americano contra o suco brasileiro.

Outro aspecto importante é a estrutura de produção dos produtores brasileiros para desempenhar as atividades relacionadas com os tratos operacionais dos pomares. Os produtores já têm tratores, pulverizadores e outros equipamentos, muitas vezes, superdimensionados. Isso ocorre porque esses produtores não têm possibilidade 
de contratar serviços terceirizados no Brasil, como ocorre nos EUA, onde existem firmas especializadas em serviços para a citricultura. Assim, nesse aspecto se relaciona com a teoria de Williamson (1985), que relata a dificuldade de o produtor escolher o melhor tipo de negócio, se sua estrutura não oferecer alternativas. Então, pode-se observar que existem problemas culturais que são de solução complicada, exigindo mudanças institucionais relevantes, e que dêem segurança e credibilidade à sua execução ao longo do tempo.

\subsubsection{Econômicos}

Neste tópico são descritos fatores econômicos como seguro, crédito, retornos, variabilidade de investimentos e políticas protecionistas que podem estar limitando o maior avanço do setor cítrico no mercado internacional.

\subsubsection{Seguro}

O seguro é um tópico de extrema importância quando se reporta à agricultura, devido a suscetibilidade deste setor a problemas não controláveis, como condições climáticas, técnicas e fitossanitárias. Assim, o grande incentivo de investimento num determinado setor por pessoas externas é evidência de segurança e menor risco de perdas financeiras. Sendo assim, pode-se inferir porque os EUA já saem em vantagem quando comparadas ao Brasil, porque os americanos possuem um sistema de seguro contra pragas e clima totalmente subsidiado pelo governo e com elevada credibilidade. Já no Brasil, o seguro agrícola está ainda se desenvolvendo e, na sua maioria, é proveniente da iniciativa privada. 


\subsubsection{Crédito: governamental e investimentos externos}

O governo brasileiro fez uma drástica mudança na quantidade de crédito rural disponível no início da década de 90. A disponibilidade de crédito entre 1970 e 1989 foi, na média, de R\$ 13 bilhões anuais, e despencou para a média de R 5 bilhões anuais na década seguinte (BACEN, 2000). Segundo a mesma fonte, chegou, em 2003 a R\$ 30 bilhões. Nos EUA, entretanto, somente um programa, Farm Bill, tem aplicações gigantescas e atrativas para os produtores.

Barros et al. (2002) também listaram as principais barreiras brasileiras para o crédito rural, entre elas: burocracia nos contratos, liberação lenta de recursos e incorporação de crises nos contratos. Nas entrevistas, foram citadas ainda distorções na aplicação de políticas de crédito para a produção, que na verdade são utilizadas para a compra de equipamentos e não para o custeio da produção. Há relatos de que esse tipo de crédito não deveria ser chamado de crédito de produção e sim crédito de investimento para maquinário.

Este fatores como burocracia de contratos e liberação lenta de recursos se tornam mais importantes quando o sistema financeiro não tem cultura em investimentos agrícolas. O problema da cultura dos investidores pode ser explicado pela ausência de um seguro agrícola bem definido e forte e/ou ainda pelas características existentes no mercado financeiro de cada país. $\mathrm{O}$ ambiente institucional de cada região também é outro aspecto que não pode ser esquecido, pois relaciona desde o ambiente macroeconômico, até o legal e institucional da sociedade, tendo, portanto, grande peso na decisão dos investidores sobre os tipos de seus investimentos.

Brasil e EUA apresentam diferenças marcantes. A Flórida tem uma cultura financeira ativa para o investimento agrícola e São Paulo apresenta uma desconfiança generalizada, criada por diversos fatores ao longo da história. 


\subsubsection{Retornos e variabilidade de investimentos}

Altas taxas de juros existentes no mercado brasileiro são mais um motivo para a falta de incentivo à entrada de investidores externos/internacionais e internos/nacionais no setor agrícola, porque estes ficam mais favoráveis a investir em ativos que detêm menor risco (menor desvio padrão do investimento). Nos E.U.A, o ambiente institucional e macroeconômico propiciam um cenário mais interessante para investimentos, mesmo considerando-se os custos de oportunidade.

Outro fator importante para a geração de investimentos externos (investidores aplicando capital na citricultura) é a credibilidade que um mercado e economia estáveis geram dentro de um país. Nos EUA, como os retornos de investimentos-padrão são baixos, como em qualquer país desenvolvido, os investidores estão sempre buscando novas alternativas.

A citricultura da Flórida e de São Paulo, na década de 80 mostraram-se boas alternativas de investimentos, com retornos anuais médios de 15,03\% e 14,92\%, respectivamente (Muraro et al. 1994).

O investimento em agricultura nos EUA, no período de 1940 a 1990, apresentou retornos médios na faixa de $10 \%$ ao ano e desvio padrão de $7 \%$ (Morgan Stanley, 1990). Comparativamente se tornou mais interessante em relação aos maiores fundos de investimentos dos EUA, como ações, que ficaram com retornos médios anuais de $18 \%$, mas com desvios na ordem de $35 \%$, mostrando que nos EUA, a agricultura tem um histórico bem positivo no mercado financeiro. Outro fator interessante é a correlação negativa da agricultura americana com os outros tipos de investimentos padrões do mercado, que correm na contramão, isto é, quando todo o mercado está em baixa, a agricultura está em alta. Assim, grandes fundos de investimentos olham a agricultura como uma diversificadora de portifólios. 
Outro aspecto importante que deve ser considerado na decisão dos investidores no setor são as relações negociais na citricultura brasileira, que foram marcadas por conflitos em dois elos da cadeia: produção e agroindústria processadora, esta última se comportando como segmento líder e dominador na cadeia cítrica.

Retornando ao fim dos anos 50 e durante a década de 60 constatou-se que a produção de laranja no Estado de São Paulo ficou subordinada à agroindústria cítrica, o que provocou uma mudança na estrutura de comercialização vigente, já que a produção passou a ser adquirida, antecipadamente, pela indústria de processamento, a qual induziu a expansão da citricultura paulista ao plantio de variedades apropriadas e dirigidas à industrialização do suco concentrado e não à de mesa. "Estabeleceu, desta forma, com a implantação da agroindústria uma citricultura dinâmica, produzida em base tecnico-organizacional moderna e inserida na lógica capitalista de produção com respostas rápidas aos estímulos de mercado" (Sifert Filho, 1992, p.21).

A indústria de processamento passou a ter a governança da cadeia cítrica no Estado e forte poder no direcionamento dos negócios. Passos, citado por Neves (1996, p.71) afirma que "uma série de fatores conjugados favoreceu a instalação da agroindústria cítrica no Estado de São Paulo. Ajustou-se, prontamente, aos 3 fatores fundamentais para a evolução da citricultura regional, que são: a) existência de um mercado internacional extremamente receptivo; b) a existência de condições ecológicas favoráveis e área disponível e suficiente em dada região e, também, c) a disponibilidade de tecnologia de produção e industrialização de citros”.

Continuando, Neves (1996, p.72) relata que "a integração vertical para trás é uma estratégia, em que a agroindústria procura garantir o fornecimento de parcelas consideráveis de matéria-prima a partir de fazendas próprias, normalmente bem dotadas tecnicamente e capazes de produzir, a custos inferiores, produtos de qualidade mais elevada. Agroindústrias no Estado de São Paulo como a Cutrale, Cargill, Citrosuco e Citrovita, por exemplo, têm fazendas próprias”. Nesse sentido, Menezes (1995, p.36) 
cita que "de um modo geral, portanto, para evitar o risco de não receber o produto em tempo e na quantidade adequada à manutenção do processamento industrial planejado, a indústria se aproxima do produtor, através de contratos ou se verticaliza para trás, minimizando custos de produção e transação".

Desta forma, a história da citricultura paulista, a partir de fins dos anos 50 até o fim do século, foi marcada pela liderança e pelas decisões tomadas pela agroindústria processadora. Naturalmente que esta foi beneficiada por legislação criada para incentivar as exportações, além de vantagens financeiras e fiscais. Neves (1996, p.73) cita as seguintes vantagens fiscais: “a) financiamentos em curto prazo (até 180 dias) para a manufatura de artigos de exportação, à juros subsidiados; b) financiamento a médio e longo prazos (180 dias a 5 anos) para implantação e expansão industrial, capital de giro e sustentação de estoque, a juros subsidiados; c) isenção de Impostos sobre os Produtos Industrializados (IPI) e de Impostos sobre Circulação de Mercadorias (ICM) sobre o valor de mercadorias exportadas; d) subsídios fiscais a exportação; e) financiamento agrícola a juros subsidiados; f) incentivos fiscais para reflorestamento". Diante desse cenário, Sifert Filho (1992, p.24) relatou que "os grupos nacionais e estrangeiros que se estabeleceram na atividade, em meados de 60, tiveram uma capacidade de acumulação que viabilizou seu processo de expansão a partir de lucros gerados na atividade cítrica, tanto no âmbito agrícola como comercial. No entanto, devese somar a este enfoque, o fato de que as indústrias desfrutaram, principalmente na década de 70, de incentivos físcais e creditícios, tanto pelo lado das exportações como do replantio, que potencializaram a capacidade de auto-acumulação”.

Historicamente, no plano da estrutura de mercado industrial, esses incentivos e facilidades favoreceram a concentração, via fusões e aquisições principalmente, da indústria processadora de suco concentrado de laranja. Amaro e Maia (1992, p.22) ao estudarem os indicadores de concentração (razão de concentração) da indústria de suco de laranja concentrado congelado para os anos de 1970, 75, 80 e 90, verificaram que a parcela detida pelas duas maiores empresas (Sucocítrico Cutrale e 
Citrosuco Paulista) passou de 63,15\% em 1970 para 64,33\% em 1990. Marino (2001) estudou também a razão da concentração, adicionando o cálculo do índice de Herfindahl-Hirschman (HHI) ${ }^{10}$. Assim, nos anos 1994/95 o HHI foi de 1.829,32; nos anos 1997/98, obteve HHI 1.756,81; e em 2000, o HHI foi de 2.035,48, evidenciando-se a elevada concentração na indústria cítrica paulista.

Nos anos 90, mesmo com o ingresso de novas empresas (passando de 12 para 16 em meados de 90) e com o aumento da capacidade instalada, os grupos Citrosuco e Cutrale, que detinham 61,5\% da capacidade instalada (extratoras), passaram ainda a deter mais da metade (52,5\%) com a instalação de outras empresas. Porém, as 4 maiores empresas continuavam responsáveis por mais de $80 \%$ da capacidade instalada em número de extratoras, havendo uma alteração com o posicionamento do Grupo Louis Dreyfus, que detinha a Frutropic e incorporou a Frutesp (Bebedouro, SP) em $3^{\circ}$ lugar, deslocando a Cargill para $4^{\circ}$ lugar, ambas de capital estrangeiro (Maia e Amaro, 1994).

Em 2001, Neves et al. (2003) verificaram que as duas maiores empresas foram responsáveis por 70,2\% do valor total de exportações de SLCC (Suco de Laranja Concentrado e Congelado) do Brasil. Já em 2002, as duas principais empresas somaram $56 \%$ do valor total exportado de suco concentrado e congelado, evidenciando-se uma certa diminuição na participação total das exportações brasileiras de suco.

Com a indústria de processamento ocupando a liderança e a condução dos negócios cítricos no Brasil, as divergências e conflitos com o setor produtivo se deram, prioritariamente, na formação de preço de matéria-prima (laranja). No princípio (até a safra 1986/87) o mercado era regulamentado pelo Governo, via Cacex, que determinava, antes do início da safra, o preço da caixa. Caso uma geada na Flórida elevasse o preço do suco concentrado e houvesse ao longo da safra um aumento no preço da caixa, o

\footnotetext{
${ }^{10}$ HHI representa a somatória das participações percentuais individuais das firmas no mercado, ao quadrado. Segundo os critérios do Federal Trade Comission e do U.S. Department of Justice, citado por Marino (2001) e descrito no 1992 Horizontal Merger Guidelines, valores inferiores a 1.000 caracterizam indústrias com baixa concentração, entre 1.000 e 1.800 moderadamente concentradas, e superior a 1.800, concentrada.
} 
citricultor não se beneficiaria, pois o preço já teria sido definido anteriormente. Com as divergências e conflitos que surgiam, a melhor solução, já na safra $86 / 87$, foi a de se estabelecer o "contrato de participação" entre as partes (produtor e indústria), uma cogestão em que o preço final recebido pelo citricultor captaria todas as variações ocorridas no mercado, eliminando o papel do governo como intermediador contratual. Esse contrato de divisão de riscos proporcionava alguma vantagem ao produtor na internalização dos ganhos de mercado internacional, diante das geadas e da queda na oferta de laranja na Flórida. Margarido, citado por Neves (1996, p.68) "verificou que no período anterior à adoção dos Contratos Padrão, a elasticidade de transmissão de preços internacionais do suco para preços ao nível do produtor de laranja era menor do que a unidade $(0,686)$ e que, posteriormente, ela passou a ser igual à unidade $(1,009)$, implicando que à adoção de contratos foi extremamente benéfica aos produtores que passaram a auferir ganhos adicionais advindos de variações nos preços de suco de laranja no mercado internacional.

O estreitamento dos negócios cítricos no Brasil se reduzindo à produção e a agroindústria, e a forte liderança desta ao longo da cadeia cítrica, não deve ter estimulado a entrada de outros agentes econômicos, já que os negócios e contratos se fecharam entre esses dois elos da cadeia, o que pode ter sido diferente na Flórida.

Com a alegação de cartelização pela indústria, os citricultores abriram processo junto à CADE (Conselho Administrativo de Defesa Econômica), alegando abuso de poder econômico da agroindústria na definição de preços. Nesse debate rompese o acordo estabelecido de co-gestão e deixa de vigorar o "Contrato de Participação", a partir da safra 94/95. O mercado é liberado, se tornando desregulamentado, e as negociações se estabelecem no "corpo a corpo", no portão da fábrica, provocando aumento nos custos de transação. Na existência do "Contrato de Participação", as indústrias se responsabilizavam pelo planejamento e operacionalização da colheita, restando ao produtor a manutenção e o exercício dos tratos culturais, isto é, as atividades de produção. 


\subsubsection{Políticas protecionistas}

Há inúmeros motivos pelos quais uma nação e/ou bloco econômico tenta se proteger contra a evolução de um produto de um outro país no seu mercado interno. Entre estes mecanismos tem-se a proteção à indústria nascente que ainda opera com elevados custos, a segurança nacional ou alimentar, as retaliações às políticas existentes em países competidores como “dumping”, os subsídios à produção e exportação, os esquemas de múltiplos preços, as quotas, as vantagens creditícias ou as tarifárias etc (Neves, 1996).

Um dos argumentos a respeito da tarifação do mercado é o de proteção interna da indústria local frente aos ajustamentos freqüentemente associados à competição internacional (Fairchild \& Fergunson, 1993, p.3). Quando produtores e/ou agroindústrias são contemplados com proteção governamental como subsídios à produção, industrialização e comercialização, ou tarifas nas importações ou quotas, são grandes os seus esforços para manterem o "status quo", evidenciando-se os grandes impasses ocorridos nas rodadas de negociação de comércio internacional, ocorridas nos últimos anos.

Segundo Neves (1996), o suco cítrico no Brasil é o mais prejudicado pelas barreiras comerciais, quando comparado aos de outros países produtores e exportadores, porque, é o maior produtor mundial de laranja e de suco cítrico congelado. Além de ser um tomador de preço no mercado internacional, se defronta com onerosas barreiras tarifárias em países importadores, gerando perdas enormes, considerando-se que 97-98\% da produção paulista é dirigida para as exportações. Estes mecanismos de proteção foram criados devido às inúmeras vantagens comparativas existentes no Brasil, quer no setor de produção da fruta, quer na agroindústria ou, ainda, nas logísticas de distribuição e transporte.

Atualmente, sobre o suco cítrico brasileiro incidem as tarifas de US\$ 418 por tonelada de suco cítrico congelado que entra nos EUA, adicionados de US\$ 40 por 
tonelada de suco cítrico congelado utilizado para a promoção do suco americano. Considerando-se o valor de 231.206 toneladas SLCC exportado para o NAFTA na safra 2002/03, e admitindo-se que quase a totalidade do suco vai para os EUA, obteve-se, através de um simples cálculo (total exportado multiplicado pelo valor da tarifa de importação), um total de imposto de aproximadamente US\$ 96 milhões, caso toda a quantidade fosse taxada.

\subsubsection{Mão-de-obra na colheita}

No Brasil, o problema da mão-de-obra na colheita não é recente. Até 1995, quando o mercado cítrico era autogerido (contratos de participação), os produtores não participavam dessa decisão, porque as indústrias organizavam e administravam todo o processo de colheita nas suas propriedades fornecedoras de matéria-prima. Isto é, toda a logística de colheita (mão-de-obra, planejamento, estruturação, controle, caminhões e equipamentos) era de responsabilidade da indústria, e o produtor era um mero coadjuvante, cujos contratos eram negociados na árvore (preço da caixa de laranja de 40,8 Kg na planta - sem colher).

Hoje, depois de alguns desentendimentos entre os elos da cadeia produtiva, indústria e produtores, em meados dos anos 90, provenientes de processos administrativos enviados ao CADE referentes à alegação dos produtores de concentração e cartelização das indústrias, o processo de colheita foi mudado, como descrito anteriormente. Assim, a partir de 1995, os produtores passaram a ser responsáveis pela colheita da laranja e os contratos são negociados na porta da indústria (preço da caixa de laranja de 40,8 Kg na porta da indústria, colhida e transportada). Pode-se dizer que a colheita de laranja é uma atividade com especificidade temporal e locacional, considerando-se a teoria de Williamson (1985), é temporal se o período específico do ano na qual a maturação da fruta está no ponto ótimo para a colheita (safra), e, locacional quando esta maturação ocorrer em locais específicos, em períodos distintos, dificultando a logística de colheita. 
Com pouco treinamento, qualquer pessoa pode realizar a colheita de laranja sem grandes dificuldades, mas só uma pessoa treinada pode realizá-la eficientemente. Os problemas começam a aparecer com a incorporação de diversos colhedores a cada ano, por um determinado período de tempo (safra) e ainda com custos financeiros e legais elevados. Dessa forma, é extremamente complicado selecionar pessoas suficientemente eficientes e profissionais para a atividade, sem grandes custos, dificultando muitas vezes, a busca no mercado por estes indivíduos, sendo necessário a absorção dessa atividade pela empresa, gerando maiores custos. Deve-se lembrar, que existe, nesse caso, o problema da especificidade temporal, porque a laranja deve ser colhida num determinado período do ano, caso contrário, as perdas são certas.

Considerando-se a incerteza e a freqüência das transações, pode-se dizer que as incertezas praticamente são muito baixas, devido a facilidade de se encontrar pessoas para desempenhar esta atividade, excluindo períodos de recessões e greves. Já a freqüência é anual e normal no segundo semestre, sendo assim, é muito oneroso o carregamento dessas pessoas, pelo dobro do tempo na atividade. Mesmo considerandose que estas pessoas poderiam desenvolver outras funções, ainda o número de colhedores é, na maioria, cinco vezes maior do que o número de funcionários fixos nas fazendas.

As respostas às entrevistas indicam que existem algumas empresas na região norte do Estado de São Paulo que passaram a oferecer serviços de colheita, carregamento e transporte de laranja, mas esta atividade ainda é muito insuficiente, principalmente, porque as empresas fornecedoras estão iniciando as atividades no setor cítrico e são, na maioria, focadas nos serviços de terceirização das atividades realizadas na cultura da cana-de-açúcar, na qual a terceirização já está totalmente disseminada.

Para Baptistella (1999), diversas alterações ocorreram no sistema de colheita da laranja a partir de 1994. Antes desse período, a operação de colheita era 
realizada pela indústria processadora, isto é, esta contratava a mão-de-obra colhedora de laranja e organizava toda a logística para o melhor suprimento e fornecimento de matéria-prima (laranja) para a indústria. Em 1994, o processo de terceirização da citricultura concretizou-se com a Lei $\mathrm{n}^{0}$ 8.949, de dezembro de 1994, que acrescentou parágrafo único ao artigo 442 da Constituição das Leis do Trabalho (CLT), autorizando a constituição de sociedade cooperativa de qualquer ramo de atividade para a prestação de serviços pelos trabalhadores, nos seguintes termos:

"Qualquer que seja o ramo de atividade da
sociedade cooperativa, não existe vínculo
empregatício entre ela e seus associados, nem
entre estes e os tomadores dos serviços daquela"

Em 1995, com o rompimento do contrato padrão de autogestão (contrato de participação), o mercado se tornou desregulamentado, causando maior preocupação no meio produtivo com a transferência de responsabilidade da colheita para os citricultores.

O processo de terceirização da mão-de-obra conseguiu apoio das principais instituições envolvidas com o setor, mas os problemas estavam somente por começar. Segundo Veiga et al. (1996), a Federação dos Empregados Rurais Assalariados do Estado de São Paulo (FERAESP), no mesmo ano, distribuiu panfletos denunciando as cooperativas de trabalho, deixando muito claro que os envolvidos nestas instituições deixariam de ter vínculo com o emprego, perdendo assim, salário, horário de trabalho, horas extras, domingos, férias, fundo de garantia, etc.

A FERAESP estava certa, porque os moldes do cooperativismo não estavam sendo seguidos, isto é, as estruturas que estavam sendo criadas estavam apenas aproveitando as vantagens legais das cooperativas (impostos, principalmente) e a cultura cooperativista não estava sendo seguida. Essas empresas, que no processo inicial deveriam compartilhar os ganhos com todos os integrantes, tinham estruturas em que 
alguns funcionários possuíam ganhos fixos incompatíveis com os moldes dessa organização, ocasionando os problemas atuais no setor. Transcorrido o ano, pouquíssimas cooperativas foram criadas, ocorrendo inversão somente nos anos seguintes, em que as cooperativas de colhedores tornaram-se instituições fortes e respeitadas, devido à seriedade de seus integrantes e à força profissional dos trabalhadores presentes.

Considerando-se as dificuldades, com os problemas sociais e culturais, encontradas com as estruturas terceirizadoras para a colheita de laranja que, na realidade, poderiam favorecer os ganhos de competitividade do setor e das relações entre os colhedores e produtores, estão possivelmente segurando um maior incremento com eficiência do segmento.

Assim, hoje, mesmo sem nenhum apoio legal, juízes estão proibindo a utilização de cooperativas de trabalho para a colheita de laranja, porque alguns indivíduos se aproveitaram do espaço legal e começaram somente a explorar as vantagens da cooperativa, sem realmente cultivar e obter grandes contribuições que o trabalho cooperado propicia. Nas entrevistas, ficou evidente que essa idéia equivocada sobre o cooperativismo não vinha dos colhedores, e sim dos seus empreiteiros "gatos" que acabavam montando estruturas que funcionavam na realidade, como uma empresa privada. O "gato", a pessoa que reunia sob sua intermediação um contingente grande de colhedores e tinha uma participação percentual dos rendimentos dos trabalhadores ainda era freqüente na colheita da laranja antes da Lei ${ }^{\circ} 8.949$ (Dez. 94).

Atualmente a colheita realizada por meio de cooperativas de trabalho na citricultura está proibida, isto é, se utilizada, o produtor pode ser multado em R\$ 1 mil por trabalhador, por dia, dependendo de sua localização, segundo os relatos nas entrevistas. Uma propriedade média pode ter aproximadamente 100 pessoas colhendo ao mesmo tempo em sua área, no sistema de cooperativa mas, se a fiscalização aparecer, resultaria numa multa, por um único dia de trabalho, de $\mathrm{R} \$ 100$ mil. Isso acaba fazendo 
com que os produtores, principalmente aqueles que passam um grande período do ano em processo de colheita (aumentando, assim, as chances de receber uma fiscalização do Ministério do Trabalho) e têm áreas próximas à cidades, contratem e registrem todas as pessoas empregadas no processo de colheita, evitando, assim, os riscos de receber multas.

Já nos EUA, o cooperativismo é bastante intenso. Reportando-se a Williamson (1985), verifica-se que na Flórida, produtores com pequenas áreas e pouca produção seriam ineficientes se fossem contratar colhedores para trabalhar um ou dois dias, ou até mesmo, horas em sua propriedade. Esses produtores teriam que pagar todos os encargos tributários e trabalhistas aos funcionários e, ainda, correriam o risco de serem processados por uns, quando não sofrer a falta de outros. Sendo assim, as cooperativas propiciam todo o auxílio aos seus cooperados quando estes estão em processo de colheita, isto é, ou se encarregam da operação de colheita ou contratam um "Caretaker" (firma terceirizadora de serviços) para realizar a operação, obtendo todas as vantagens de uma cooperativa (estrutura com escala) como o poder de barganha entre outras vantagens para seus cooperados.

Reportando-se à maneira como a colheita é realizada nos EUA, encontram-se maquinários específicos para a colheita de frutas diretamente das árvores, diferentemente do que ocorre no Brasil. Esse processo que é facilitado principalmente porque as variedades encontradas (Hamlin, Valência e Natal), apresentam períodos de maturação específicos durante a safra, isto é, somente uma colheita por safra. Já no Brasil, os produtores plantam um número significativo da variedade Pêra, que tem várias colheitas durante uma safra, isto é, dependendo das condições climáticas, esta variedade pode produzir de uma a três colheitas (produção de laranja) por planta. Quando se considera a colheita mecanizada, é preciso pensar em máquinas que seguram no tronco e mexem as árvores ou que passam um rolo com hastes sobre os galhos das copas para derrubar as frutas e qualquer desses mecanismos causaria problemas à citricultura paulista, porque em apenas uma operação na variedade Pêra, a máquina colheria 
(derrubaria) laranjas maduras, laranjas verdes e flores (possíveis futuras frutas), causando, certamente, prejuízos de receita à empresa. Por outro lado, na Flórida, esta prática está cada vez mais comum devido aos elevados custos de mão-de-obra para a colheita de laranja praticados naquela região.

Em relação à mão-de-obra utilizada na citricultura, o estado norteamericano se estruturou e implantou um sistema mecanizado para a colheita, solucionando seus problemas. Em São Paulo, se os problemas persistirem a citricultura deverá procurar por soluções, talvez, similares às encontradas na Flórida, porém, não somente transferindo tecnologia, mas adaptando-a à sua realidade.

\subsubsection{Técnicos}

Quando são considerados os problemas técnicos, quantidade de itens que devem ser explanados, porém, nesta seção, o enfoque se apóia em problemas coletados nas entrevistas.

Primeiramente, existem características marcantes quando se consideram as variedades utilizadas nas duas citriculturas. Na Flórida não se planta a variedade Laranja Pêra; no Brasil ela representa $44,1 \%$ do total de plantas do parque cítrico do Estado (FUNDECITRUS, 2003). Essa variedade tem número de colheitas distintas, dependendo das condições climáticas de cada ano, o que dificulta o planejamento de colheita; guarda, porém, características excelentes para a fabricação do SLCC, sendo de vital importância na qualidade do suco produzido. Assim, no Brasil, é comum observarse áreas sendo colhidas duas ou até três vezes, num mesmo ano. Isso não acontece com as variedades utilizadas nos EUA, favorecendo a organização (a colheita é realizada em 6 meses, bem definidos durante o ano), mesmo considerando-se a maior ociosidade do maquinário, graças ao período de sua utilização. Pode-se dizer que esta característica 
favorece a instalação de empresas terceirizadoras de colheita na Flórida, porque, no início do ano, fecha-se a programação anual, com as áreas e períodos a serem colhidas.

Basaldi et al. (1995), analisando a demanda da força de trabalho e a distribuição regional na agricultura paulista verificaram, em termos da variação de demanda mensal, que a citricultura apresentava um padrão de variação sazonal com oscilações leves ou atenuadas. O fato de a citricultura no Estado de São Paulo reunir variedades precoces, meia-estação e tardias, representava uma vantagem à indústria processadora que seria alimentada por matéria-prima (laranja) por um período de 9 meses ou mais; por outro lado, era uma desvantagem à colheita, pois a demanda por mão-de-obra não era uniforme ou homogênea de acordo com os requerimentos diferenciados na quantidade de mão-de-obra requerida, impostas pelas diferentes variedades e produções temporãs.

Portanto, no Brasil, a diversidade de variedades e a possibilidade de ocorrerem colheitas temporãs tornam impraticável um planejamento preciso da colheita. Recorrendo a Williamson (1985), conclui-se que as variedades predominantes têm características específicas, sendo necessário obter-se contratos muitos bem estabelecidos e completos para que problemas não ocorram, lembrando que os agentes têm racionalidade limitada. Nesse caso, os contratos ficariam incompletos, sendo talvez, essencial a integração dessa atividade pela empresa.

Além da colheita, a cultura absorve bom contingente de mão-de-obra (pulverizações, adubações, aplicações de herbicidas, calagem e poda, entre outras). Cada sistema de produção tem uma característica distinta; neste sentido, a facilidade e a disponibilidade do produtor em relação à contratação de serviços externos dependerá do sistema empregado na sua propriedade. Não se pode ignorar que numa mesma propriedade encontrem-se diferentes sistemas de produção (manutenção de pomares com idades distintas, diversas variedades com diferentes espaçamentos entre plantas, etc) requerendo tratos culturais diferenciados. 
Nesse sentido, a dificuldade de se ter mão-de-obra treinada para as especificidades operacionais da prática de uso e serviços de diferentes insumos em variedades diversas é um sério problema na citricultura paulista. Estudos de custos comparativos de produção entre São Paulo e Flórida (Muraro e Amaro, 1990; Neves et al, 1990; Muraro, 1995) mostraram que os custos operacionais com mão-de-obra e máquinas eram elevados na citricultura paulista. Uma explicação se apoiava no fato de a mão-de-obra utilizada na citricultura paulista ser menos qualificada e receber salário inferior que os encontrados na Flórida e, nesta região utilizava-se capital mais intensivamente (mecanização alta), resultando em custos de produção maiores.

A pouca qualificação da mão-de-obra paulista fazia com que em parte as despesas com fertilizantes, corretivos e defensivos agrícolas fossem relativamente maiores no estado. Em parte, dois estudos (Arruda et al., 1988 e Ferreira et al., 1990) justificaram que a aplicação desses insumos não era efetuada por mão-de-obra qualificada e treinada para as práticas, ocorrendo desperdícios e perdas. Revelaram que o não treinamento da mão-de-obra era responsável pela utilização de práticas culturais inadequadas pela má aplicação (na maioria das vezes, excessivas) de defensivos, adubação e pela correção de acidez insuficiente. Para Ferreira et al. (1990, p.391) "embora a adubação e a calagem, bem orientadas, possam contribuir para aumentar em até $40 \%$ a produtividade, a recomendação correta de adubação para os pomares ainda enfrenta insuficiente suporte experimental, o que leva a se apoiar, preferencialmente, nas recomendações disponíveis em pesquisas de outros países e nos cálculos de extração de nutrientes pela colheita".

Na Flórida, a existência do gerenciamento da produção dos "Caretakers" e de firmas de investimentos e gerenciamento, corrigem temporalmente essas distorções tão constantes na citricultura paulista, com tecnologia apropriada e bem controlada. 
Nas entrevistas, ficou claro que algumas operações como a aplicação de herbicidas e de poda são pouco específicas e seriam, de imediato, incorporadas pelos proprietários brasileiros, principalmente por não forneceram riscos altos no caso de um erro ou de demora na aplicação e, nem mesmo, a necessidade de se levantar um histórico da área, como apóiam os pressupostos teóricos de Williamson (1985). No caso das adubações, é uma atividade mais específica, já que necessita de um histórico, podendo ser facilmente fornecido pelo contratante. Essa atividade tem um período de aplicação de poucos meses, o que facilita seu planejamento. Nas pulverizações, o processo é complicado, principalmente no Brasil, onde as pulverizações não são bem definidas, podendo ocorrer infestações que necessitem de controle imediato. Esse controle pode ser dificultado se a propriedade não dispor de máquinas e pulverizadores para a operação. Basta lembrar o aparecimento de doenças de etiologias desconhecidas como a CVC (Clorose Variegada dos Citros) no $2^{\circ}$ qüinqüênio dos anos 90, e a MSC (Morte Súbita dos Citros) nestes últimos anos, cujo controle e combate fitossanitários não foram bem estabelecidos.

Depois de uma breve lista de operações e algumas inferências relacionando a teoria de Williamson, têm-se a seguir um maior detalhamento de cada operação, relacionado-a com a teoria.

A aplicação de herbicida é uma atividade pouco específica fisicamente (especificidade física), já que o ativo pode ser utilizado em outras culturas com a mesma finalidade. Por exemplo, com uma barra de herbicida pode-se aplicar o herbicida tanto numa área com laranja ou com café com a mesma finalidade. Apresenta também pouca especificidade humana e dedicado; humano, já que com pouco treinamento consegue-se exercer a atividade e dedicado, pois os investimentos são os mesmos utilizados para vários clientes. A especificidade temporal também é pequena, porque mesmo apresentando períodos determinados para aplicação, eles podem ser adiados ou adiantados sem grandes problemas e, ainda, seu planejamento pode ser feito com certa facilidade. Apresenta pouca incerteza, pois se utilizando das técnicas adequadas, os 
objetivos são alcançados e ainda possui relativamente baixa freqüência, sendo realizada apenas algumas vezes durante a safra. Agrega-se, ainda, a operação de roçagem, que apresenta praticamente as mesmas características quando comparada com a aplicação de herbicida. Desta forma, essas atividades poderiam ser facilmente terceirizadas pelos produtores, segundo a teoria de Williamson (1985).

A operação de poda das árvores segue também os pontos expostos anteriormente, podendo ser utilizada tanto na poda de laranjeiras quanto de cercas vivas ou de outras árvores. Não apresenta incerteza e a freqüência é de baixa utilização na safra pelo produtor. As entrevistas mostraram que algumas empresas até estavam propiciando esse tipo de serviço em São Paulo, mas os custos de contratação de pessoal eram tão altos que os produtores não contratavam alegando que provavelmente em uma safra, se considerassem os preços praticados no mercado para a terceirização, poderiam adquirir a máquina de poda no final de apenas uma única safra. Portanto, a atividade também é possível de ser terceirizada (compra no mercado), segundo a teoria, desde que as firmas terceirizadoras trabalhem com racionalidade, isto é, com custos compatíveis com as operações fornecidas.

A adubação já é uma atividade com um grau maior de especificidade, porque necessita de um histórico sobre a quantidade e os tipos de fertilizantes utilizados nos anos anteriores, mas isso é facilmente contornado com o fornecimento do histórico da área pelo produtor ou mesmo por meio de análise de solo. Os conhecimentos humanos são específicos por cultura, mas os equipamentos utilizados são praticamente os mesmos. A incerteza e freqüência são baixas levando-se em conta as características da operação e a freqüência com que é realizada. Os períodos de adubação são mais específicos, com ajustes possíveis e um planejamento prévio é facilmente estruturado. Portanto, a terceirização é possível de ser praticada com pequenos ajustes.

A operação de pulverização, certamente é a atividade com maior grau de especificidade quando comparada com as anteriores, porque necessita de equipamentos 
específicos, os conhecimentos são aplicados somente numa cultura específica e os períodos de operações não são bem definidos, dificultando o planejamento das atividades. Além disso, apresenta alta freqüência, porque é realizada em vários momentos durante a safra e também tem grande incerteza, pois é praticamente impossível garantir, mesmo seguindo-se todas as normas técnicas existentes, que a doença ou a praga será controlada. Isso porque qualquer variação de um componente não controlado no campo (por exemplo, o clima) pode alterar totalmente o resultado da operação. A especificidade temporal é alta, pois dada a infestação na área, poucos dias até a aplicação do defensivo podem ser irreversíveis para o cuidado da planta, principalmente por se tratar de uma cultura perene. Portanto, essa operação cultural, seguindo a teoria, seria muito difícil de ser terceirizada, isto ainda, sem se considerar os aspectos estratégicos. E existem certas pragas e/ou doenças, porém, que ocorrem em períodos menos freqüentes e que apresentam menores incertezas no controle, e ainda menor especificidade temporal, podendo ser terceirizadas. Pode-se concluir, então, que as pulverizações não podem ser terceirizadas, talvez apenas uma parte do processo.

Métodos de controle de doenças como as que ocorrem em São Paulo não são muito comuns na Flórida, porque naquele Estado, as pulverizações são bem definidas e distribuídas ao longo do ano, facilitando o planejamento das organizações e a criação de empresas prestadoras desse tipo de serviço. Pulverizações não definidas dificultam toda a organização e o planejamento das operações durante o ano, porque a necessidade de pulverização somente é detectada por meio de inspeções periódicas nos pomares verificando-se os níveis de infestação de doença, e as operações são realizadas quando são ultrapassados os níveis recomendados.

Atualmente, existem em operação em São Paulo algumas práticas que podem ser consideradas terceirizadas como: produção de mudas, assessoria técnica, produção de culturas anuais nas entre linhas de laranja. 
Seguindo-se a mesma linha de raciocínio anteriormente relatado, relacionando-se as atividades práticas implementadas com a teoria, a produção de mudas pode ser considerada uma atividade específica, com grande incerteza e baixa freqüência, mas em muitos casos é realizada internamente e não explicada pela teoria na totalidade, ela é entendida quando o setor estratégico é adicionado ao negócio. A especificidade da atividade é humana, física, locacional, dedicado e temporal, de acordo com a teoria e explicando-se porque esta é internalizada pelos produtores. Ao mesmo tempo, a freqüência de utilização é baixa (poucas vezes na safra - plantio) e a incerteza é relativamente alta, por se tratar de um ser vivo susceptível a inúmeras adversidades. Mas, para a realização interna da atividade necessita-se de certa escala e de alto investimento financeiro e intelectual. Salienta-se que, com essa base teórica, pode-se explicar a existência tanto em São Paulo como na Flórida de estruturas produtoras de mudas cítricas que operam no mercado, que possuem contratos de fornecimento e que são integradas, evidenciando-se uma estrutura que apresenta as três formas de organização, agindo conjuntamente no mercado.

A produção de mudas cítricas passou por grandes modificações nos últimos anos, principalmente devido a problemas fitossanitários enfrentados pela citricultura paulista, como por exemplo, a Clorose Variegada dos Citros (CVC), o Cancro Cítrico e a Morte Súbita dos Citros (MSC). Foram implementadas mudanças em todos os aspectos neste segmento, desde a parte legal até as tecnologias de produção. Por exemplo, antes as mudas podiam ser produzidas em campo aberto; hoje, somente podese produzir mudas de cítricos em ambiente protegido, isto é, em casas de vegetação.

Já a assessoria técnica realizada por consultores ou engenheiros agrônomos especialistas, é uma prática relativamente antiga no setor em São Paulo e atuante principalmente em médias e grandes propriedades. Atualmente, existem diversos grupos de consultores nas principais regiões produtoras do estado que prestam serviços aos produtores/empresários da laranja. Esses serviços são ligados à consultoria diretamente, isto é, eles dão a indicação de controle de doenças, indicam como fazer 
adubação de pomares, os métodos de manejo e controle de doenças, etc. Relacionandose à teoria, a assessoria técnica tem maior grau de especificidade, quando comparada com o sistema de produção de mudas. Requer profissionais mais capacitados. É, portanto, uma atividade que pode ser terceirizada, principalmente por pequenos produtores.

Já a produção de culturas anuais entre as linhas de laranja é uma atividade com inúmeras especificidades, mas que não está no foco da atividade da empresa; nesse caso, portanto, a atividade seria facilmente terceirizada principalmente devido aos altos investimentos, tanto de capital quanto humano, para exercê-la. Mas, por outro lado, o conhecimento e maquinário empregado nessa atividade poderiam ser utilizados em outras atividades, como o plantio de culturas anuais em área total e não somente entre linhas de outras culturas.

É evidente que algumas operações nas propriedades agrícolas têm suas especificidades (temporal e locacional), riscos e freqüência, tornando-se estratégicas, forçando as empresas a realizarem sua incorporação para facilitar o seu gerenciamento principalmente, quando se consideram as duas regiões produtoras, que apesar de produzirem laranja para suco concentrado e congelado, apresentam especificidades bem distintas na área de produção.

Portanto, pode-se inferir que algumas atividades da produção de laranja podem ser consideradas de simples terceirização, outras apresentam poucos ou muitos pontos a favor ou contra, quando se relaciona a teoria com a realidade.

Finalizando, no Quadro 7 tem-se uma comparação entre os principais problemas, potencialidades e possibilidades relacionados com a terceirização na produção cítrica no Estado de São Paulo, evidenciando-se quais as atividades que poderiam ser realizadas pelo mercado e quais não poderiam, levando-se em 
consideração a teoria de Williamson (1985) sobre especificidades dos ativos, incerteza e freqüência das operações.

\begin{tabular}{|l|c|c|c|c|}
\hline Operação & Especificidade dos Ativos & Incerteza $^{2}$ & Frequência $^{3}$ & Operação $^{\mathbf{4}}$ \\
\hline Adubação & Baixa & Média & Baixa & Via Mercado $^{-1}$ \\
\hline Assessoria Técnica & Baixa & Baixa & Alta & Via Mercado \\
\hline Colheita & Baixa & Baixa & Média & Via Mercado \\
\hline Culturas anuais & Alta & Alta & Baixa & Via Mercado \\
\hline Herbicida & Baixa & Baixa & Média & Via Mercado \\
\hline Mudas & Alta & Alta & Média & Via Contrato \\
\hline Poda & Baixa & Baixa & Baixa & Via Mercado \\
\hline Pulverização & Alta & Alta & Alta & Via Contrato \\
\hline Roçagem & Baixa & Baixa & Baixa & Via Mercado \\
\hline
\end{tabular}

Quadro 7 - Caracterização da especificidade dos ativos, incerteza e freqüência de algumas operações da produção cítrica de São Paulo.

Fonte: Dados de pesquisa.

${ }^{1}$ Especificidade de ativos: relacionando a especificidade temporal, dedicado, locacional, humana, física,

${ }^{2}$ Incerteza: riscos envolvidos na operação (chance de falhas)

3 freqüência: número de operações por safra (Baixa - 1 vez; Média - 2 vezes; Alta mais que 3 vezes)

${ }^{4}$ Operação: pode ser realizada no mercado (via mercado) através de terceirizações ou realizada internamente na empresa por meio de integração vertical (via hierárquica), ou via outras formas intermediárias como mista (via contratos).

No Quadro 7, pode-se observar que as operações de produção de mudas e pulverizações são as únicas operações relacionadas que apresentam certas restrições para a implementação da terceirização, sendo, portanto, possivelmente realizadas internamente pelas empresas. $\mathrm{O}$ restante apresenta grandes potencialidades de terceirização imediata, porém, devem-se considerar os fatores como: estratégias 
empresariais (foco de negócios), ambiente institucional, ambiente macroeconômico, entre outros, numa análise mais completa e conclusiva sobre terceirização.

Concluindo, fica a questão: será que os modelos de gerenciamento adotados na Flórida podem ser eficientes no Brasil? A resposta seria sim, mas salienta-se que não se pode simplesmente transferir e aplicar os modelos. Deve-se antes de tudo, adaptá-los à realidade vigente. Outro aspecto importante é o do ambiente institucional de cada região, principalmente porque o que é bom para uma região, pode não ser para outra; o mesmo pode ser dito em relação à eficiência e à eficácia, que em São Paulo mesmo não tendo uma gama maior de agentes envolvidos e tantas opções como na citricultura da Flórida, o estado paulista continua sendo o maior produtor e exportador de suco de laranja do mundo. Finalizando, pode-se inferir que as especificidades dos ativos de ambas as regiões são distintas, vide as diferentes formas de organização encontradas em cada estado produtor, e que cada um persegue a eficiência diante da disponibilidade e dos níveis existentes de recursos. 


\section{CONCLUSÕES}

A partir dos anos 80, os Estados de São Paulo, no Brasil, e da Flórida, nos Estados Unidos vêm se constituindo como líderes e como as duas maiores forças competitivas na produção de suco concentrado de laranja (cerca de $90 \%$ da produção mundial) e com perspectiva de continuarem soberanos ainda por muitos anos.

A forte concorrência internacional e a acirrada competitividade na citricultura entre os Estados vêm chamando por bom tempo a atenção de pesquisadores nas áreas administrativa e econômica quanto ao aprofundamento de estudos que investiguem as estratégias gerenciais e os procedimentos econômicos, visando a manutenção e o fortalecimento dessas hegemonias na cadeia cítrica mundial.

Essas estratégias remetem à compreensão e ao entendimento da gestão estratégica da cadeia e o estudo de mecanismos que busquem a eficiência e a eficácia de suas ações e iniciativas. Neste sentido, a análise das formas de organização da produção cítrica nos dois estados, sob a ótica de propriedade, gerenciamento e investimentos e as decisões e operacionalização de instrumentos sobre a gestão da produção são direções inerentes à compreensão da manutenção de competitividade na cadeia cítrica o que foi focado neste estudo.

Por meio da análise das formas de organização da produção cítrica no estado de São Paulo e estado da Flórida têm-se as seguintes inferências: 
1. No estado da Flórida há uma participação maior de diferentes agentes econômicos no gerenciamento da produção, propriedade da terra e na crescente atratividade de fundos de investimentos devido a inúmeros fatores:

a) Forte protecionismo interno em defesa da citricultura via mecanismos de subsídios domésticos tornando o setor muito atrativo em termos de aplicações de fundos de investimentos, trazendo a participação de agentes econômicos urbanos (absentee, etc.). A confiabilidade da aplicação desses fundos se apóia ainda no forte protecionismo legal imposto aos competidores externos, como o Brasil, com a implementação de barreiras comerciais, principalmente as tarifárias e nãotarifárias, estas associadas aos entraves fitossanitários que barram os produtos brasileiros e dão mais seguridade aos fundos de investimentos americanos;

b) A boa organização do setor aliada à credibilidade de suas estatísticas e órgãos de informação e geração de facilidades (Florida Citrus Commission, Florida Citrus Exchange, entre outras), bem como o envolvimento das Universidades e do Governo por meio do United States Department of Agriculture (USDA) dão boa visibilidade do setor aos agentes econômicos americanos, atraindo-os às aplicações financeiras e às aquisições patrimoniais;

c) À melhor organização do setor somam-se, ainda, as características da cadeia cítrica que não evidenciam alta concentração em mãos de poucos agentes econômicos no setor industrial, se apoiando em cooperativas principalmente; das condições técnicas e climáticas que estabelecem períodos programados para o planejamento e dimensionamento das práticas culturais, que não só incentivam a participação de inúmeros agentes econômicos (firmas de investimento e gerenciamento, cooperativas, caretakers, absentee, etc) nos investimentos, como também favorecem e estimulam a entrada de firmas de gerenciamento da produção, principalmente as de terceirização; 
d) Rentabilidade dos investimentos na citricultura americana, quando comparados a investimentos alternativos, apresentam grande atratibilidade, porque são fontes com alto retorno e baixo risco (desvio padrão) relativos quando considerados os mesmos níveis de retorno para outros investimentos.

2. Em São Paulo verificou-se, temporalmente, uma gama menor de agentes econômicos no gerenciamento da produção, propriedade da terra e de aplicações financeiras no setor, devido a diversos fatores. São os seguintes:

a) $\mathrm{O}$ fato de a indústria processadora ter sido o fator estimulador de produção a partir dos anos 60, direcionando as variedades e locais para a produção de laranja, conduziu o parque cítrico para a produção de Suco de Laranja Concentrado e Congelado (SLCC) trazendo retornos elevados nas primeiras três décadas (1960, 70 e 80), incentivados pelas geadas ocorridas na Flórida. Assim, as organizações cítricas existentes no Estado, na maioria, não apresentavam eficiência e/ou eficácia nos seus métodos de administração e gerenciamento da produção, não por falta de profissionalismo e competência dos agentes envolvidos, mas sim pelos preços atrativos, pelo ambiente institucional e pelas estruturas de governança caracterizados no período. Mas, em meados dos anos 80 e na década de 90 , essas ineficiências se tornaram evidentes, com anos de retornos pouco atrativos, gerando o início de conflitos entre a indústria e o produtor na formação do preço da matéria-prima laranja. Portanto, a história da citricultura em São Paulo exemplifica as formas de organização existentes no parque cítrico atual, a que levou a indústria processadora à liderança da movimentação financeira e à governança da cadeia cítrica no país.

b) $\mathrm{O}$ ambiente institucional também tem bastante peso na influência de modelos para investimento externo (investidores nacionais e/ou internacionais) na citricultura paulista. Crises, vários planos econômicos, altas taxas de juros para 
investimentos, inflação, entre outros, não tornavam atrativo o investimento de capital nesta atividade, no Brasil.

c) As entrevistas mostraram que, dado o atual ambiente institucional de São Paulo, os problemas culturais enraizados e provenientes do processo histórico ou mesmo da transmissão dessa cultura para as gerações seguintes, são características importantes que vêm limitando a inserção de modelos de gerenciamento da produção, como a terceirização na produção de laranja;

d) Ainda não se pode esquecer, do ambiente institucional e dos aspectos técnicos relacionados com as práticas de manejo nos fatores culturais e com a força de trabalho. Cada um desses fatores interfere direta ou indiretamente nas decisões dos empresários na busca por processos mais eficientes de produção na empresa. Por exemplo, quando se trata dos aspectos macroeconômicos, como a taxa de juros real da economia, entende-se a importância desses aspectos para os produtores. Deve-se lembrar também que o setor de produção de laranja apresenta grandes especificidades de ativos para cada prática de manejo desenvolvida na produção, que se somam aos aspectos técnicos da produção e da mão-de-obra, sendo, desta forma, condicionante na caracterização da produção de cada região cítrica;

e) Atualmente, os produtores do negócio cítrico estão buscando atitudes profissionais e gerenciais mais consistentes, investigando novas alternativas para aumentar a eficiência e a eficácia do processo de gerenciamento e administração da produção, evidenciando que, num período não muito longo a citricultura passará por novos modelos de gerenciamento e estrutura de organização.

Sintetizando: os modelos de investimento e administração existentes na citricultura de São Paulo e da Flórida apresentam diversas formas alternativas para o financiamento e gerenciamento de propriedades. Alguns atraem e facilitam a entrada de 
investidores na citricultura, como na Flórida; outros, não estimulam e os afastam devido à incerteza e aos riscos existentes, como no Brasil. As perspectivas para o setor cítrico dessas regiões são positivas quando considerados os modelos de negócios empregados e as possibilidades de intercâmbio de modelos. As prováveis causas para diferentes desempenhos das duas regiões produtoras são, em grande parte, institucionais e culturais, que não percebidos e ajustados poderão limitar o ganho de competitividade do setor. 
ANEXOS 
ANEXO A - Roteiro das entrevistas.

Quadro 8 - Questionário utilizado no levantamento de informações no estado de São Paulo e da Flórida.

\begin{tabular}{|l}
\hline \multicolumn{1}{|c|}{ Questões } \\
\hline - Como o(a) senhor(a) descreveria seu negócio de produção de laranja? (por \\
exemplo, operação própria, serviços terceirizados, sociedade, tamanho das \\
propriedades) \\
- O(A) senhor(a) poderia descrever os sistemas ou métodos de gerenciamento \\
de uma fazenda de laranja? (por exemplo, empresas terceirizadoras, \\
sociedades de fazendas e firmas ou produção, investidores) \\
- Como uma empresa que gerencia e/ou administra uma fazenda conduz seu \\
negócio? Existem ações com investidores? (por exemplo, como é o \\
gerenciamento de contas?) Como os riscos são gerenciados (empresas \\
tercerizadoras - caretakers e/ou de comercialização são contratados pelas \\
fazendas de proprietários/investidores)? \\
Existem políticas para minimização dos riscos dentro do negócio (por \\
exemplo, baixa taxa de financiamento? seguro (área, árvore, outro)? anos \\
de baixos retornos/preços? utilizam os preços futuros para se proteger no \\
futuro? Existe algum tipo de assistência do governo?) \\
O(A) senhor(a) conhece algum tipo de negócio em que sejam vendidas \\
ações para investidores, os fundos utilizados para o desenvolvimento de \\
pomares de laranja e que todos os lucros (perdas) sejam distribuídos entre \\
os detentores dos títulos? (Existe algum tipo de agência reguladora neste \\
mercado para regulamentar este tipo de negócio? - por exemplo, Comissão \\
de Valores Mobiliários (CVM) ou Securities and Exchange Commission \\
(SEC))
\end{tabular}

Fonte: Dragone et al. (2002) e esta pesquisa. 
ANEXO B - Entrevistados no estado de São Paulo (Brasil).

\section{Sr. Ademerval Garcia}

Cargo: Presidente da ABECITRUS

Local: Ribeirão Preto - SP

Data: $26 / 02 / 03$

\section{Sr. Agostinho Morio Boggio}

Cargo: Engenheiro Agrônomo da Coopercitrus

Local: Bebedouro - SP

Data: 08/05/03

\section{Dr. Augusto Gameiro}

Cargo: Pesquisador do CEPEA

Local: Piracicaba

Data: 08/07/03

\section{Sr. Cícero Augusto Massari}

Cargo: Gerente Técnico da FUNDECITRUS

Local: Araraquara - SP

Data: $24 / 03 / 03$

\section{Sr. Frederico Fonseca Lopes}

Cargo: Ex-Gerente da Citrosantos e Mestrando em Administração-FEARP/USP

Local: Cordeirópolis - SP

Data: 07/06/03 


\section{Sr. Henrique de Freitas}

Cargo: Diretor de SLCC da Coimbra/Dreyfus no Brasil

Local: Bebedouro - SP

Data: $27 / 02 / 03$

\section{Sr. Henrique Fiorese}

Cargo: Diretor da Fiorese Citrus, Membro do Conselho da COMCITRUS e Presidente da VIVECITRUS.

Local: Monte Azul - SP

Data: $18 / 07 / 03$

\section{Sr. Jacques Benchetrit}

Cargo: Engenheiro das primeiras indústrias de SLCC no Brasil, produtor de laranja e mudas certificadas de citrus

Local: Araraquara - SP

Data: $19 / 04 / 03$

\section{Sr. Joaquim Dragone}

Cargo: Vice-presidente da VIVECITRUS, Produtor de laranja e mudas certificadas de citrus

Local: Araraquara - SP

Data: $19 / 04 / 03$

\section{Sr. Juliano Ayres}

Cargo: Gerente cientifico da FUNDECITRUS

Local: Araraquara - SP

Data: $24 / 03 / 03$ 


\section{Srta. Margarete Boteon}

Cargo: Pesquisadora do CEPEA

Local: Piracicaba-SP

Data: 05/05/03

\section{Prof. Marcos Fava Neves}

Cargo: Prof. Doutor da FEARP/USP

Local: Ribeirão Preto - SP

Data: $12 / 05 / 03$

\section{Prof. Ronald P. Muraro}

Cargo: Professor e Extensionista da Universidade da Flórida

Local: Itirapina - SP

Data: 08/07/03 
ANEXO C - Entrevistados no estado da Flórida (EUA).

\section{Allen Morris}

Cargo: Vice-Presidente da Capital Agro Investments - Região Sudeste

Local: Orlando - Flórida

Data: $16 / 10 / 01$

\section{Charles A. Counter}

Cargo: Gerente de Produção da Haynes City Citrus Growers - Cooperativa

Local: Haines City - Flórida

Data: $17 / 10 / 01$

\section{Charles W. Harrison Jr.}

Cargo: Presidente da C.W. Harrison Incorp. - Caretaker

Local: Vero Beach - Flórida

Data: 05/11/01

\section{Charlie Russ}

Cargo: Proprietário da Orange Service Company - Caretaker

Local: Arcadia - Flórida

Data: 05/11/01

\section{James (Jim) R. Dilley}

Cargo: Proprietário da Roland L. Dilley \& Son, Incorp. - Viveiro

Local: Avon Park - Flórida

Data: $10 / 11 / 01$ 


\section{Jerry Newlin}

Cargo: Vice-Presidente do Setor de Produção da Orange Co. - Investimento

Local: Arcadia - Flórida

Data: $05 / 11 / 01$

\section{Joe L. Davis, JR.}

Cargo: Presidente da Davis Citrus Management Incorp. - Produtor

Local: Avon Park - Flórida

Data: $10 / 11 / 01$

\section{Karick A. Price Jr}

Cargo: Comprador de Frutas da Louis Dreyfus Citrus - Indústria

Local: Winter Garden - Flórida

Data: $17 / 10 / 01$

\section{Mark D. Dunn}

Cargo: Tesoureiro da CPI (Cooperative Producers Incorporation)- Cooperativa Local: Immokalee - Flórida

Data: $07 / 11 / 01$

\section{Marvin Kahn}

Cargo: Presidente da Kahn Grove Service Company - Caretaker

Local: Sebring - Flórida

Data: $19 / 10 / 01$

\section{Michael O. Carlton}

Cargo: Diretor da Florida Citrus Mutual - Associação

Local: Lakeland - Flórida

Data: 16/10/01 


\section{Mike Ziegler}

Cargo: Presidente da Agricultural Resource Management - Consultoria

Local: Vero Beach - Flórida

Data: $29 / 10 / 01$

\section{Norman Todd}

Cargo: Presidente da Grove Crafters - Investimentos

Local: LaBelle - Flórida

Data: 09/11/01

\section{Peter D. Spyke}

Cargo: Presidente da Arapaho Citrus Management Incorporated - Caretaker

Local: Fort Pierce - Flórida

Data: $29 / 10 / 01$

\section{Ray Bentley}

Cargo: Presidente da Bentley Bros. - Caretaker

Local: Haines City - Flórida

Data: $15 / 10 / 01$

\section{Robert W. Teston}

Cargo: Vice-Presidente Executivo do Farm Credit - Banco

Local: Lakeland - Flórida

Data: $26 / 10 / 01$

\section{Robert E "Bob” Carden, Jr.}

Cargo: Presidente Carden \& Sprott Insurance Agency - Seguradora

Local: Winter Haven - Flórida

Data: $26 / 10 / 01$ 


\section{Steve Farr}

Cargo: Gerente de Produção da Ben Hill Griffin Corporation - Empresa

Local: Frostproof - Flórida

Data: $19 / 10 / 01$

\section{Dr. Thomas H. Spreen}

Cargo: Professor da Universidade da Flórida

Local: Gainesville - Flórida

Data: $10 / 10 / 01$

\section{W. Garvie Hall}

Cargo: Presidente da Citrus Partners Management Incorp. - Sociedade

Local: Bartow - Flórida

Data: $26 / 10 / 01$ 


\section{REFERÊNCIAS BIBLIOGRÁFICAS}

ASSOCIAÇÃO BRASILEIRA DOS EXPORTADORES DE CÍTRICOS ABECITRUS. Exportações: série histórica. http://www.abecitrus.com.br (04 mar. 2003)

AMARO, A.A.; MAIA, M.L. Estrutura organizacional da citricultura no Estado de São Paulo. /Apresentado ao 7. Internacional Congress of Citriculture, Aciriale, 1992/

AMARO, A.A.; VICENTE, M.C.M.; BAPTISTELLA, C.S.L. Citricultura paulista: tecnologia e mão-de-obra. Laranja, v.22, n.1, p.1-38, jun. 2001.

ARRUDA, S.T.; GHILARDI, A.A.; PRATES, H.S. Caracterização das propriedades e dos pomares citrícolas do Estado de São Paulo. São Paulo: Secretaria da Agricultura e do Abastecimento do Estado de São Paulo, Instituto de Economia Agrícola, 1988. 26p. (Relatório de Pesquisa 09/88)

AZEVEDO, P.F. Integração vertical e barganha. São Paulo, 1996. 220p. Tese (Doutorado) - Faculdade de Economia, Administração e Contabilidade, Universidade de São Paulo.

BAPTISTELLA, C.S.L.; PINO, F.A.; FRANCISCO, V.L.F.S. Os colhedores na agroindústria da laranja no Estado de São Paulo. Laranja, v.20, n.2, p.259-317, jun. 1999. 
BANCO CENTRAL DO BRASIL - BACEN. Séries temporais. http://www.bacen.gov.br (08 mar. 03)

BARROS, M.H.C; VITTI, A.; BOTEON, M. Há dinheiro no setor hortícola ? Hortifruti Brasil, v.1, n.6, p.14-16, out. 2002.

BIALOSKORSKI, S. Agribusiness cooperativo: economia, doutrina e estratégias de gestão. Piracicaba, 1994. 135p. Dissertação (M.S.) - Escola Superior de Agricultura “Luiz de Queiroz”, Universidade de São Paulo.

BESANKO, D.; DRAVONE, D.; SHANLEY, M. The economics of strategy. New York: John Wiley \& Sons, 1996. 644p.

BRASIL. Ministério do Desenvolvimento, Indústria e Comércio Exterior. Secretaria de Comércio Exterior. Informativo Secex, v.6, n.33, p.5-8, jan. 2003.

BRICKLEY, J.A.; SMITH, C.W., ZIMMERMAN, J.L. Managerial economics and organizational architecture. Boston: Irwin/McGraw-Hill, 2001. 616p.

COASE, R. The nature of the firm. In: COASE, R. The firm, the market, and the law. Chicago: University of Chicago Press, 1988. p.33-55.

DRAGONE, D.S.; AZEVEDO, A.; NEVES, E.M.; FERNANDEZ, W.; MURARO, R.P.; SPREEN, T.H. Investment and production management arrangements within the Florida citrus industry. Laranja, v.23, n.1, p.19-36, jun. 2002.

DRUKER, P.F. A administração na próxima sociedade. São Paulo: Abril/Nobel, 2002. $211 \mathrm{p}$.

FAO. FAOSTAT agriculture data. http://www.fao.org (20 Oct. 02) 
FASULO, T.R. Florida citrus organizations. Gainesville: University of Florida, 1998. $5 \mathrm{p}$.

FAIRCHILD, G.; FERGUNSON, J. Free trade, protection and Florida citrus growers. Citrus Industry, v.74, n.1, p.33-37, 1993.

FERREIRA, C.R.R.P.T.; VICENTE, M.C.M.; NOGUEIRA, E.A.; AMARO, A.A. Aspectos econômicos de adubação em citros na agricultura paulista. Laranja, v.2, n.1, p.383-407, jun. 1990.

FUNDAÇÃO CARGILL. AgroCargill. A nova ferramenta na agricultura. http://cargill.sao.zaz.com.br/publi/prod/hp11a.htm (07 maio 03)

FUNDO DE DEFESA DA CITRICULTURA - FUNDECITRUS. A ciência a serviço da citricultura. http://www.fundecitrus.com.br (05 mar. 2003)

GARCIA, A. nova análise da citricultura brasileira nos anos noventa. Laranja, v.14, n.1, p.1-30, jun. 1993.

HANCOCK AGRICULTURAL INVESTMENT GROUP. Risk/return. http://www.haig.jhancock.com (03 mar. 2003)

HASSE, G. A laranja no Brasil, 1500 à 1987. São Paulo: Coopercitrus Industrial FRUTESP/Duprat \& Iobe, 1987. 296p.

INSTITUTO BRASILEIRO DE GEOGRAFIA E ESTATÍSTICA - IBGE. Download. http://www.sidra.ibge.gov.br (08 mar. 03)

INSTITUTO DE ECONOMIA AGRÍCOLA - IEA. Bando de dados. http://www.iea.sp.gov.br (08 mar. 03) 
KASSAI, L. Investidores trocam bolsa pela soja. Gazeta Mercantil, São Paulo, 24 abr. 2003. p.B-16.

LANDX INVESTMENTS. Annual returns. http://www.landx.com (03 Mar. 2003)

LAURENTI, A.C. A terceirização na agricultura: a dissociação entre a propriedade e o uso dos instrumentos de trabalho na moderna produção agrícola paranaense. Campinas, 1996. 245p. Tese (Doutorado) - Instituto de Economia, Universidade de Campinas.

MAIA, M.L.; AMARO, A.A. Estrutura de mercado de suco cítrico no Brasil. Laranja, v.13, n.1, p.123-163, jun.1992.

MALHOTRA, N.K. Pesquisa de marketing: uma orientação aplicada. Trad. de N. Montingelli Jr. e A. A. de Farias. Porto Alegre: Bookman, 2001. 719p.

MARGARIDO, M.A. Análise de transmissão de preços internacionais de suco de laranja para preços ao nível de produtor de laranja no Estado de São Paulo. In: CONGRESSO BRASILEIRO DE ECONOMIA E SOCIOLOGIA RURAL, 33., Curitiba, 1995. Anais. Curitiba: SNA, 1995. v.1, p.258-274.

MARINO, M.K. Avaliação da intervenção do sistema brasileiro de defesa da concorrência no sistema agroindustrial da laranja. São Carlos, 2001. 114p. Dissertação (M.S.) - Universidade Federal de São Carlos.

MAXIMILIANO, A.C.A. Teoria geral da administração. São Paulo: Atlas, 2000. $530 \mathrm{p}$. 
MENEZES, V.B. A indústria da laranja: competitividade e tendências. Salvador: Secretaria do Planejamento Ciência e Tecnologia/Fundação Centro de Projetos e Estudos, 1993. 125p.

MORRIS, A.; MORRIS, K. Economics aspects of the orange juice industry. Citrus Industry, v.76, n.8, p.42-49, 1995.

MURARO, R.P.; AMARO, A.A. An overview of Florida (USA) and Sao Paulo (Brazil): processed orange industries with comparative costs and returns 1979-80, through 1987-88 seasons. Gainesville: University of Florida, Institute of Food and Agriculture Science, 1990. 49p. (Economic Information Report, 274)

MURARO, R.P.; AMARO, A.A. Comparative costs of producing oranges in Florida (USA), Sao Paulo (Brazil), Argentina, Uruguay and Vera Cruz (Mexico). Gainesville: University of Florida, Food and Resource Economics Department, 1994. 49p.

MURARO, R.P.; AMARO, A.A. Comparative costs of producing oranges in Florida (USA), Sao Paulo (Brazil), Vera Cruz (Mexico) and other citrus production regions 1991/92, 1992/93 and 1993/94. Gainesville: University of Florida, Internacional Agriculture Trade and Development Center, 1995. 23p.

NEVES, E.M; SARTORELLI, S.R.P.; ZEN, S.de; MURARO, R.P. Economia da produção citrícola nos USA e Brasil: análise comparativa de custo de manutenção de pomares. Laranja, v.11, n.2, p.409-428, jun. 1990.

NEVES, E.M. Os acordos comerciais e o suco cítrico: um novo cenário ? Folha da Laranja, v.6, n.1, p.8-9, 1994. 
NEVES, E.M. A competitividade da agroindústria citrícola brasileira: vantagens comparativas e o dilema das barreiras comerciais. Piracicaba: ESALQ/CNPq, 1996. 125p. (Relatório de Pesquisa)

NEVES, E.M.; DRAGONE, D.S.; RODRIGUES, L. Conhecendo a citricultura: atualidades e tendências de mercado. /Apresentado ao Curso de Citricultura do Departamento de Produção Vegetal, Escola Superior de Agricultura "Luiz de Queiroz”, Universidade de São Paulo, Piracicaba, 2003/

NEVES, M.F. Sistema agroindustrial citrícola: um exemplo de quase integração no agribusiness brasileiro. São Paulo, 1995. 116p. Dissertação (M.S.) - Faculdade de Economia, Administração e Contabilidade, Universidade de São Paulo.

NEVES, M.F. Sumário executivo: cadeia cítrica no Estado de São Paulo. São Paulo: Grupo PENSA, 1999. 4p.

NEVES, M.F.; VAL, A.M.; MARINO, M.K. The orange network in Brazil. Journal of the Fruit Processing: Fruit Processing/Flussiges, v.12, n.10, p.435-437, oct. 2002.

POMPEU, R.B.; NEVES, E.M. Ações coletivas na citricultura: análise interna da organização e desempenho das associações de produtores e das indústrias. Laranja, v.20, n.1, p.1-34, jun. 1999.

RODRIGUEZ, O.; VIÉGAS, F.; POMPEU, J.; AMARO, A.A. Citricultura brasileira. 2.ed. Campinas: Fundação Cargill, 1991. 492p.

SANDRONI, P. Novíssimo dicionário de economia. 7.ed. São Paulo: Best Seller, 2001. $649 \mathrm{p}$. 
SIFERT FILHO, N.F. Citricultura e indústria: organização e mercados. Rio Claro: UNESP/IGCE, 1992. 62p. (Rascunho, 22)

SPREEN, T.H.; MURARO, R.P. Florida citrus industry overview. Gainesville: University of Florida, Food and Resources Economics Department, 1999. 9p.

SPREEN, T.H. International trade and evolution of multinational firms: the structure of the orange processing industries of Florida and Sao Paulo. /Apresentado ao International Agricultural Trade \& Policy Conference, Florida, 2001/

WILLIAMSON, O.E. The economic institutions of capitalism. New York: The Free Press, Division of Simon \& Schuster Inc, 1987. 450p.

WISE, M.R. Farmland investment strategy: the opportunity of the 1990s. Champaign: WGI Publishing, 1993. 269p.

VIEGAS, F. de C.P.; GUIMARÃES, J.A.B. Citrus fruit processing in Brazil. In: INTERNATIONAL CONGRESS OF FRUIT JUICE, São Paulo, 1991. Anais. São Paulo: SNA, 1991. p.1-27.

VIEGA, J.E.R.; VICENTE, M.C.M.; BAPTISTELLA, C.S.L. Trabalho volante, mudanças à vista. Informações Econômicas, v.26, n.4, p.55-58, abr. 1996.

ZYBERSZTAJN, D. Estruturas de governança e coordenação do agribusiness: uma aplicação da nova economia das instituições. São Paulo, 1995. 238p. Tese (LivreDocência) - Faculdade de Economia, Administração e Contabilidade, Universidade de São Paulo.

ZYLBERSZTAJN, D.; NEVES, M.F. (Org.). Economia e gestão dos negócios agroalimentares. São Paulo: Pioneira, 2000. 428p. 